\begin{tabular}{|c|c|c|c|c|}
\hline \multirow[t]{2}{*}{ ENGINEERING CHANGE NOTICE } & \multirow[b]{2}{*}{ Page 1 of 8} & \multirow{2}{*}{$\begin{array}{l}\text { 区 DM } \\
\square \text { FM } \\
\square \text { тм }\end{array}$} & 1a. ECN & 720716 R 0 \\
\hline & & & $\begin{array}{l}\text { 1b. Proj. } \\
\text { ECN }\end{array}$ & W- \\
\hline
\end{tabular}

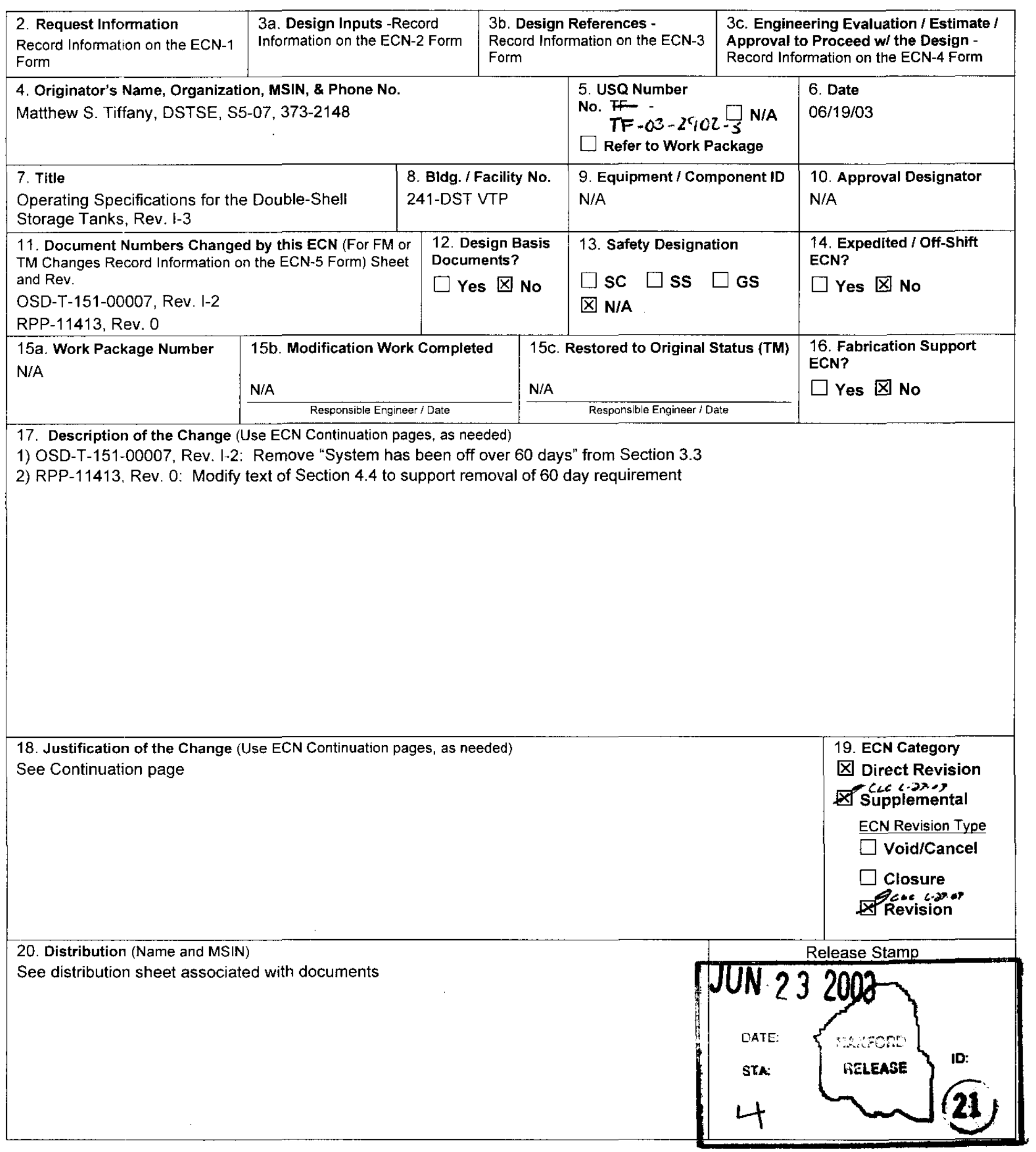




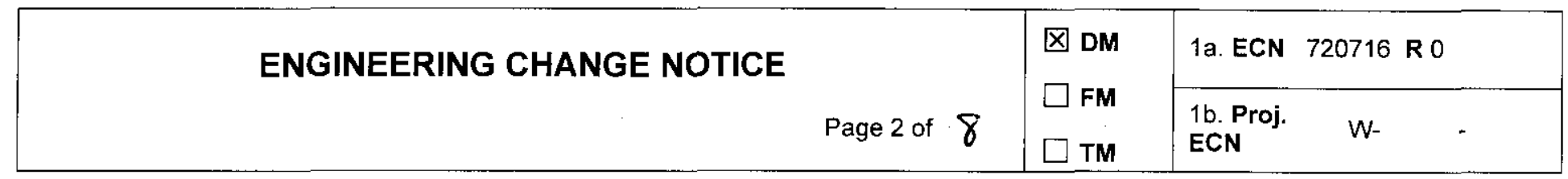

21. Design Check Record Information on the ECN-6 Form

\section{Design Verification Required?}

$\square$ Yes $X$ No

If $Y e s$, as a minimum attach the one page checklist from TFC-ENG-DESIGN-P-17.

\section{Closeout / Cancel/Void}

$\square$ Yes $X$ No

If Yes, Record Information on the ECN-7 Form and attach form(s).

24. Revisions Planned (Include a brief description of the contents of each revision)

No Revisions to this ECN are planned

Note: All Revisions shall have the approvals of the affected organizations as identified in block 9 "Approval Designator," on page 1 of this ECN.

25a. Commercial Grade Item Dedication Numbers (associated with this design change)

N/A 25b. Engineering Data Transmittal Numbers (associated with this design change, e.g., new drawings, new documents) N/A 26a. Design Cost Estimate

N/A

27. Field Change Notice(s) Used? (Used for ECN Revisions only)

D Yes $\searrow$ No

If Yes, Record Information on the ECN-8 Form attach form(s) and identify permanent changes.

\section{Approvals}

26b. Materials / Procurement Costs N/A
$6 / 19 / 03$ $6,19 \cdot 03$

Team Lead/Lead Engr. Mark H Brown gnu $1 \mathrm{~B}$

Resp. Engineer__Mark H Brown

Resp. Manager M Fish

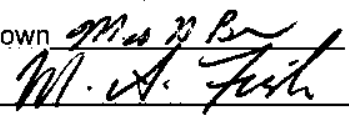

Quality Assurance

IS\&H Engineer

NS\&L Engineer

Environ. Engineer P. Miller

Project Engineer $6 \cdot 15-3$ $6 / 1963$

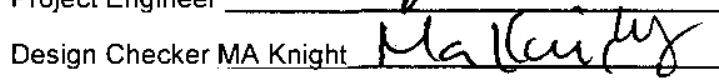

Design Verifier

Operations cesalgon

Radcon

Other

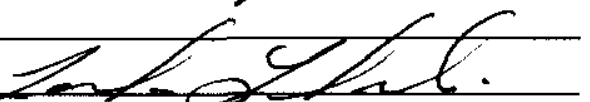

other $6 / 19 / 03$ $6-19-03$

\section{6c. Estimated Labor Hours}

N/A

NOTE: ECN Revisions are required to record and approve all FCN's issued during the field modification work process. If the FCN's have not changed the original design media then they are just incorporated into the $E C N$ file via an ECN revision. If the $F C N$ did change the original design media then the ECN Revision will include the necessary engineering changes to the original design media changes.

Signature

Date

Originator/Design Agent

Professional Engineer

Project Engineer

Quality Assurance

Safety

Designer

Environ. Engineer

Other_Facilities Manager: D Scott

Other

\section{DEPARTMENT OF ENERGY / OFFICE OF RIVER PROTECTION}

Signature or a Control Number that tracks the Approval Signature 


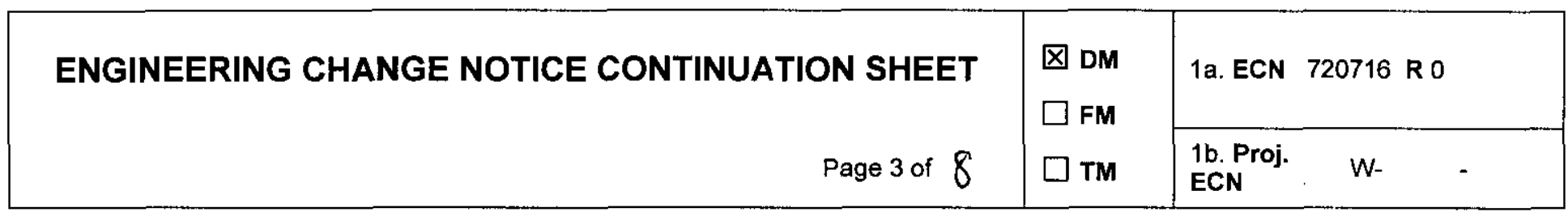

RPP-11413, Technical Basis for Ventilation Requirements in Tank Farms Operating Specification Documents, states the following: "Review of the HEPA standards and guidance documents, requirements for HEPA filters at other DOE facilities, and discussions with Tank Farm personnel could not find any specific basis or need for this specification related to HEPA filters. The general consensus of Hanford Site tank farm personnel involved in the Hanford tank farm ventilation systems is that no need for this specification limit can be defined at this time. This requirement may have been implemented due to past tank conditions that no longer exist, have been reduced, or are only specific to a few tanks with special conditions."

In reviewing the historical changes to the OSDs, the "60 day" requirement originally applied to only the DCRTs. It is believed that this was because of moist and warm air conditions in the tank vapor space, the existence of an open path to the filter train when not operating the exhauster, and "cave-like" conditions in the filter pit conducive to the formation of condensate on the HEPA filters within their housings. Wetting of HEPA filters has been shown to degrade their strength. ERDA 76-21, Nuclear Air Cleaning Handbook, states: "In some systems, frequent (even monthly) testing is often specified where the environment is particularly severe; the frequency may be reduced if experience indicates a lesser frequency is satisfactory." Somehow the "60-day" DCRT requirement was subsequently generalized in its application to the other tank farm ventilation systems. The basis was not documented.

Because recent efforts have been unsuccessful at positively identifying the basis for the 60-day testing requirement, it is recommended that the requirement be removed from the OSDs. This will support continued operation of ventilation systems in the event that they are off-line for over 60 days. 


\begin{tabular}{|c|c|c|c|c|c|}
\hline \multirow{2}{*}{$\begin{array}{c}\text { ECN - } 1 \\
\text { ENGINEERING REQUEST FORM }\end{array}$} & & \multirow{2}{*}{$\begin{array}{l}\text { 囚 DM } \\
\square \text { FM } \\
\square \text { TM }\end{array}$} & \multicolumn{3}{|c|}{ 1a. ECN 720716 R 0} \\
\hline & Page 4 of 8 & & $\begin{array}{l}\text { 1b. Proj } \\
\text { ECN }\end{array}$ & W- & . \\
\hline
\end{tabular}

\begin{tabular}{|l|l|l|}
\hline $\begin{array}{l}\text { Requestor's Name (Print) } \\
\text { M. S. Tiffany }\end{array}$ & Date & REA Reference \\
& & N/A \\
\hline Equipment Name & & $\begin{array}{l}\text { Estimated Need Date } \\
06 / 20 / 03\end{array}$ \\
\hline 241-SY VTP & & \\
\hline
\end{tabular}

Problem/Issue Statement

OSD-T-151-00007, Rev I-2 with technical basis document RPP-11413, Rev. 0 contains a requirement to test the frequency of the High Efficiency Particulate Air (HEPA) filters if the ventilation system has been off for more than 60 days. No technical basis could be found for this requirement.

Purpose for the Proposed Modification

The 241-SY Primary Ventilation system B-Train has been offline for more than 60 days. It is desired to put it online but due to limited resources, HEPA filter efficiency testing can not be performed in a timely manner. With the proposed modification, the 241-SY Primary Ventilation System B-Train can be returned to service.

Basis for the Estimated Need Date

B-Train is desired to be returned to service to maintain compliance with LCO 3.2.1 in the event that the A-Train becomes inoperable.

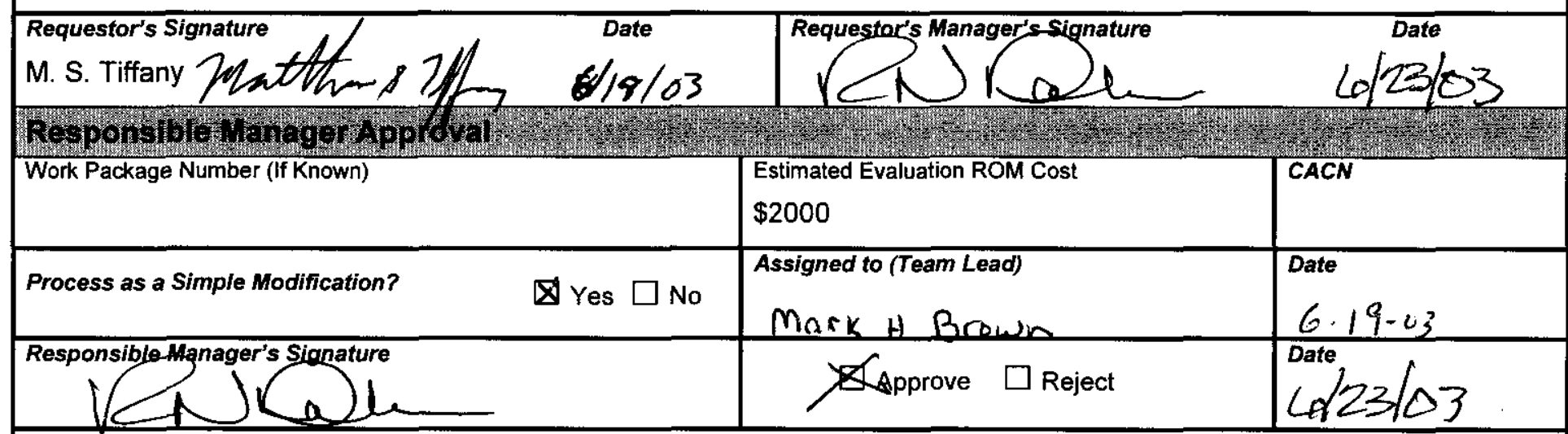

If rejected, explain reason for rejection:

(Once rejected the Responsible Manager returns the request to the Requestor's Manager)

italicized text items need to be addressed. Standard text items need to be addressed as applicable to the problem/issue described. 


\begin{tabular}{|c|c|c|}
\hline $\begin{array}{c}\text { ECN - } 5 \\
\text { DRAWING / DOCUMENT CHANGE LIST FORM }\end{array}$ & $\begin{array}{l}\text { 囚 DM } \\
\square \text { FM }\end{array}$ & 1a. ECN 720716 R 0 \\
\hline Page 5 of 8 & & $\begin{array}{l}\text { 1b. Proj. } \\
\text { ECN }\end{array}$ \\
\hline
\end{tabular}

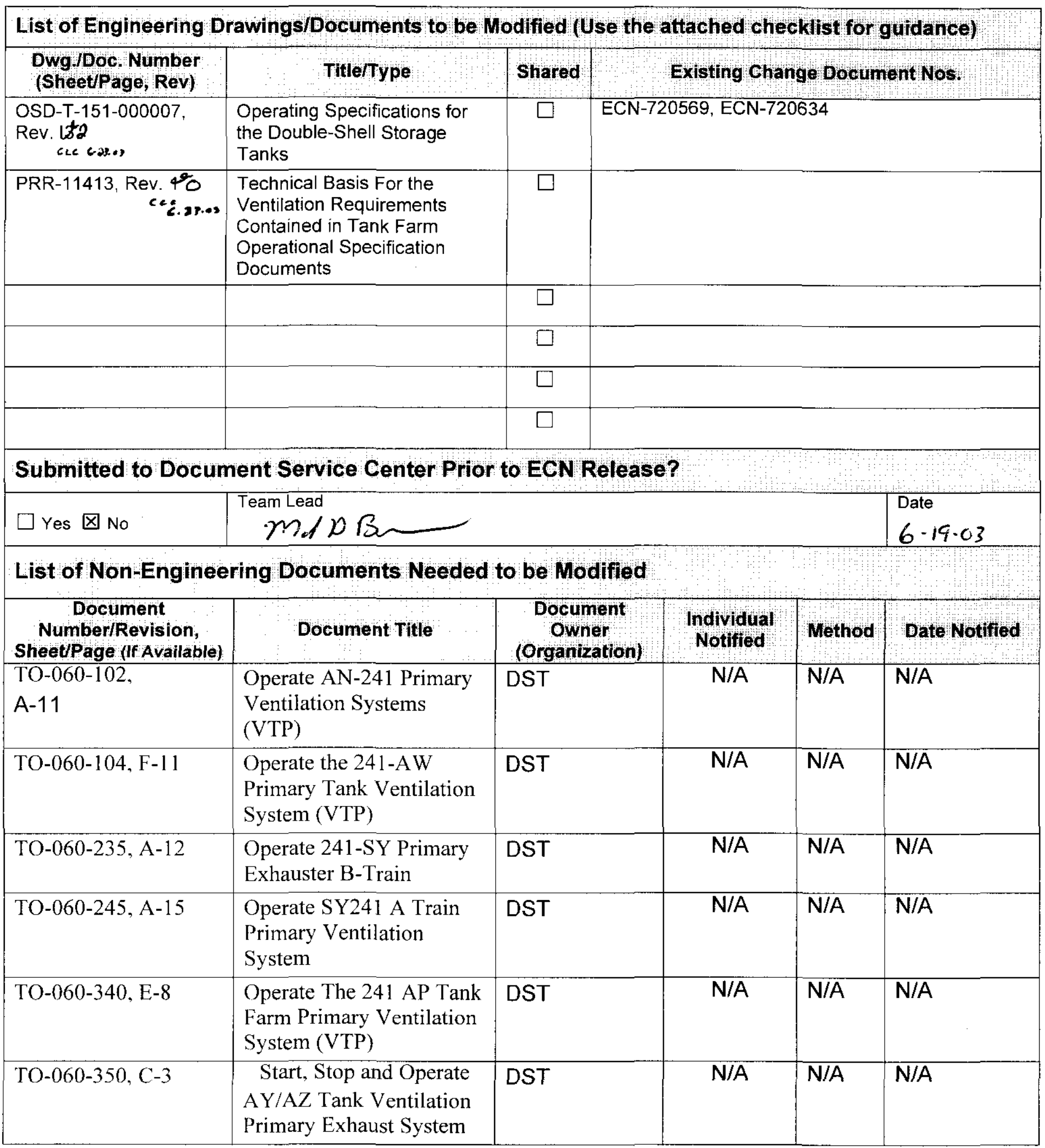




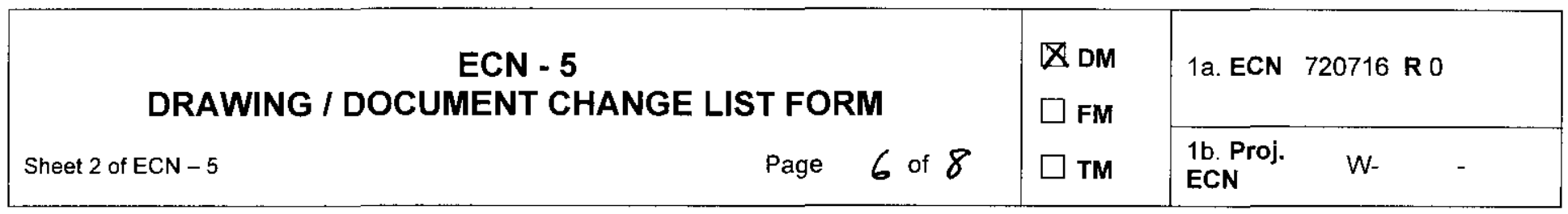

\begin{tabular}{|c|c|c|c|}
\hline \multicolumn{4}{|c|}{ Drawings/Documents to be Modified Checklist } \\
\hline System Design Description & $\square$ Yes $\otimes$ No $\square$ N/A & Operating Procedure & 囚Yes $\square$ No $\square$ N/A \\
\hline Functional Design Criteria & $\square$ Yes $\square$ No 冈N/A & System/Subsystem Specifications & $\square$ Yes $\square$ No $\otimes$ N/A \\
\hline Functional Requirements & $\square$ Yes $\square$ No $\otimes$ N/A & Engineering Flow Diagram Drawing & $\square$ Yes $\square$ No 冈N/A \\
\hline Operating Specification & $凶$ Yes $\square$ No $\square$ N/A & General Arrangement Drawing & $\square$ Yes $\square$ No $囚 \mathrm{~N} / \mathrm{A}$ \\
\hline Criticality Specification & $\square$ Yes $\triangle$ No $\square$ N/A & Material Specification & $\square$ Yes $\square$ No $囚 \mathrm{~N} / \mathrm{A}$ \\
\hline Conceptual Design Report & $\square$ Yes $\square$ No $区$ N/A & Sampling Plan & $\square$ Yes $\square$ No $\otimes$ N/A \\
\hline Detailed Design Report & $\square$ Yes $\square$ No X N/A & Inspection Plan & $\square$ Yes $\square$ No $\otimes$ N/A \\
\hline Equipment Specification & $\square$ Yes $\square$ No N/A & Radiation Control Procedure & $\square$ Yes $\square$ No $\otimes$ N/A \\
\hline Procurement Specification & $\square$ Yes $\square$ No $\otimes N / A$ & Spare Parts List & $\square$ Yes $\square$ No N/A \\
\hline Construction Specification & $\square$ Yes $\square$ No $\otimes N / A$ & Test Specification & $\square$ Yes $\square$ No $囚$ N/A \\
\hline Vendor Information & $\square$ Yes $\square$ No $\otimes$ N/A & Test Plan & $\square$ Yes $\square$ No $\otimes$ N/A \\
\hline Operations / Maintenance Manual & $\square$ Yes $\square$ No 囚 N/A & Acceptance Test Procedure & $\square$ Yes $\square$ No $\bigotimes$ N/A \\
\hline Safety Analysis / FSAR / SAR / DSA & $\square$ Yes $囚$ No $\square$ N/A & Pre-Operational Test Procedure & $\square$ Yes $\square$ No $\otimes$ N/A \\
\hline Technical Safety Requirement & $\square$ Yes $囚$ No $\square$ N/A & Operational Test Procedure & $\square$ Yes $\square$ No 囚 N/A \\
\hline Master Equipment List & $\square$ Yes $\square$ No $囚 \mathrm{~N} / \mathrm{A}$ & ASME Coded Item / Vessel & $\square$ Yes $\square$ No $\otimes$ N/A \\
\hline Safety Equipment List & $\square$ Yes $\square$ No 冈 N/A & Human Factor Consideration & $\square$ Yes $\square$ No $囚 \mathrm{~N} / \mathrm{A}$ \\
\hline Radiation Work Permit & $\square$ Yes $\square$ No $\bigotimes$ N/A & $\begin{array}{l}\text { Automated Control Configuration } \\
\text { Procedure }\end{array}$ & $\square$ Yes $\square$ No 冈 N/A \\
\hline Environmental Requirement & $\square$ Yes $\square$ No $囚$ N/A & $\begin{array}{l}\text { Computer / Automated Control } \\
\text { Software Plan } \\
\end{array}$ & $\square$ Yes $\square$ No $\otimes$ N/A \\
\hline Environmental Permit & $\square$ Yes $\square$ No $区$ N/A & Raceway / Cable Schedules & $\square$ Yes $\square$ No $\otimes$ N/A \\
\hline Seismic / Stress / Structural Analysis & $\square$ Yes $囚$ No $\square$ N/A & Work Control Procedure & $\square$ Yes $\square$ No $\otimes$ N/A \\
\hline Design Report & $\square$ Yes $\square$ No X N/A & Corrective Maintenance Procedure & $\square$ Yes $\square$ No X N/A \\
\hline Interface Control Drawing & $\square$ Yes $\square$ No $\otimes$ N/A & Process Control Plan & $\square$ Yes $\otimes$ No $\square$ N/A \\
\hline Calibration Procedure & $\square$ Yes $\square$ No X N/A & Process Control Procedure & $\square$ Yes $\otimes$ No $\square$ N/A \\
\hline Preventive Maintenance Procedure & $\square$ Yes $\square$ No 囚 N/A & Flow Sheet & $\square$ Yes $\square$ No N N/A \\
\hline Engineering Procedure & $\square$ Yes $囚$ No $\square$ N/A & Purchase Requisition & $\square$ Yes $\square$ No 冈N/A \\
\hline Security Plan & $\square$ Yes $\square$ No N N/A & Hazards Analysis & $\square$ Yes $\otimes$ No $\square$ N/A \\
\hline \multirow[t]{3}{*}{ Emergency Plan } & $\square$ Yes $\square$ No X N/A & JCS PM Activity Datasheet & $\square$ Yes $\square$ No $\otimes$ N/A \\
\hline & $\square$ Yes $\square$ No $\square$ N/A & & $\square$ Yes $\square$ No $\square$ N/A \\
\hline & $\square$ Yes $\square$ No $\square$ N/A & & $\square$ Yes $\square$ No $\square$ N/A \\
\hline
\end{tabular}




\begin{tabular}{|c|c|c|c|c|c|c|}
\hline \multirow{2}{*}{\multicolumn{2}{|c|}{$\begin{array}{c}\text { ECN }-6 \\
\text { DESIGN CHECK LIST } \\
\text { Page }\end{array}$}} & \multirow[b]{2}{*}{ of 8} & \multirow{2}{*}{$\begin{array}{l}\text { 区 DM } \\
\square \text { FM } \\
\square \text { TM }\end{array}$} & \multicolumn{3}{|c|}{$\begin{array}{c}\text { cas s-as.at } \\
720834 \text { R } 0 \\
716\end{array}$} \\
\hline & & & & $\begin{array}{l}\text { 1b. Proj. } \\
\text { ECN }\end{array}$ & W- & \\
\hline
\end{tabular}

\section{Design Details/Attributes (to be filled out by the change originator) identified in the ECN.}

\begin{tabular}{|c|c|c|c|}
\hline 1. Issue/Problem Statement included & 区 Yes $\square$ No $\square$ N/A & $\begin{array}{l}\text { 21. Basis for Selected Altemative } \\
\text { explained, including assumptions }\end{array}$ & $\square$ Yes $\square$ No $\otimes$ N/A \\
\hline $\begin{array}{l}\text { 2. Safety/Commitment/Programmatic } \\
\text { Impacts identified - NEPA Documentation } \\
\text { completed }\end{array}$ & $\square$ Yes $\square$ No $\bigotimes$ N/A & $\begin{array}{l}\text { 22. Potential Component/System Impacts } \\
\text { identified and resolved }\end{array}$ & $\square$ Yes $\square$ No $\square$ N/A \\
\hline $\begin{array}{l}\text { 3. System/Equipment/Personnel /mpacts } \\
\text { identified }\end{array}$ & $\square$ Yes $\square$ No $\square$ N/A & $\begin{array}{l}\text { 23. Potential Software Impacts identified } \\
\text { and resolved }\end{array}$ & $\square$ Yes $\square$ No $\square$ N/A \\
\hline 4. Technical Evaluation included & $\square$ Yes $\square$ No $\square$ N/A & $\begin{array}{l}\text { 24. Potential Safety Impacts are identified } \\
\text { and resolved (e.g., energized electrical } \\
\text { equipment) }\end{array}$ & $\square$ Yes $\square$ No $\square$ N/A \\
\hline 5. Compliance $w /$ Design Basis identified & $\square$ Yes $\square$ No $\square$ N/A & $\begin{array}{l}\text { 25. Modification is Constructible and can be } \\
\text { implemented }\end{array}$ & $\square$ Yes $\square$ No $\bigotimes$ N/A \\
\hline 6. Assumptions/Sources clearly identified & $\square$ Yes $\square$ No $\square$ N/A & 26. Design considers Operational Impacts & $\square$ Yes $\square$ No $\otimes$ N/A \\
\hline $\begin{array}{l}\text { 7. Affected Documents and Databases } \\
\text { clearly identified }\end{array}$ & $\triangle$ Yes $\square$ No $\square$ N/A & 27. Contamination Controls are planned & $\square$ Yes $\square$ No $\otimes$ N/A \\
\hline 8. Inputs Verified & $\square$ Yes $\square$ No $\square$ N/A & $\begin{array}{l}\text { 28. Pre-Installation/Mockup/Prototype } \\
\text { Testing planned }\end{array}$ & $\square$ Yes $\square$ No $\otimes$ N/A \\
\hline $\begin{array}{l}\text { 9. Required Function(s) / changes clearty } \\
\text { identified }\end{array}$ & $\otimes$ Yes $\square$ No $\square$ N/A & $\begin{array}{l}\text { 29. Sketches/Drawings for } \\
\text { Tools/Fabricated Components included }\end{array}$ & $\square$ Yes $\square$ No $\otimes$ N/A \\
\hline $\begin{array}{l}\text { 10. Safety Basis/Commitments/Concems } \\
\text { evaluated }\end{array}$ & $\square$ Yes $\square$ No $\otimes$ N/A & 30. Hardware Design described & $\square$ Yes $\square$ No $\square$ N/A \\
\hline $\begin{array}{l}\text { 11. Application of Industry } \\
\text { Standards/Codes explained }\end{array}$ & $\square$ Yes $\square$ No $\square$ N/A & 31. Software/Firmware Design described & $\square$ Yes $\square$ No $\square$ N/A \\
\hline $\begin{array}{l}\text { 12. Proper Analytical Techniques } \\
\text { employed }\end{array}$ & $\square$ Yes $\square$ No $\square$ N/A & $\begin{array}{l}\text { 32. Inspections (per Codes \& Standards) / } \\
\text { Quality Checks included }\end{array}$ & $\square$ Yes $\square$ No $\otimes \mathrm{N} / \mathrm{A}$ \\
\hline 13. Interfaces evaluated and identified & $\square$ Yes $\square$ No $\square$ N/A & 33. Dimensions and Tolerances included & $\square$ Yes $\square$ No $囚 \mathrm{~N} / \mathrm{A}$ \\
\hline $\begin{array}{l}\text { 14. Material/Component Compatibility } \\
\text { evaluated }\end{array}$ & $\square$ Yes $\square$ No $\square$ N/A & $\begin{array}{l}\text { 34. Sketches/Drawings for Installation } \\
\text { included }\end{array}$ & $\square$ Yes $\square$ No $\otimes \mathrm{N} / \mathrm{A}$ \\
\hline $\begin{array}{l}\text { 15. ALARAVRadiological controls/chemical } \\
\text { hazards evaluated }\end{array}$ & $\square$ Yes $\square$ No $\square$ N/A & $\begin{array}{l}\text { 35. Housekeeping/Personnel Safety } \\
\text { Requirements identified }\end{array}$ & $\square$ Yes $\square$ No $\otimes$ N/A \\
\hline 16. Human/Machine Interface evaluated & No $\bigotimes \mathrm{N} / \mathrm{A}$ & $\begin{array}{l}\text { 36. Walkdown(s) performed/Labeling } \\
\text { Correct }\end{array}$ & $\square$ Yes $\square$ No $\otimes \mathrm{N} / \mathrm{A}$ \\
\hline 17. Program impacts evaluated & $\square$ Yes $\square$ No $\square$ N/A & $\begin{array}{l}\text { 37. Acceptance Test generated and } \\
\text { Acceptance Criteria included }\end{array}$ & $\square$ Yes $\square$ No $\otimes$ N/A \\
\hline 18. Design Basis Calculations updated & $\square$ Yes $\square$ No $\otimes$ N/A & 38. M\&TE Requirements identified & $\square$ Yes $\square$ No $\square$ N/A \\
\hline $\begin{array}{l}\text { 19. Altematives described/evaluated and } \\
\text { address resolution of problem }\end{array}$ & $\square$ Yes $\square$ No $\otimes$ N/A & $\begin{array}{l}\text { 39. Training/Qualification of Test Personnel } \\
\text { identified }\end{array}$ & $\square$ Yes $\square$ No $\otimes$ N/A \\
\hline $\begin{array}{l}\text { 20. Impacts on Maintenance and OPS } \\
\text { described }\end{array}$ & $\square$ Yes $\square$ No $囚$ N/A & 40. Safety and Hazards Analysis assessed & $\square$ Yes $\square$ No $\otimes \mathrm{N} / \mathrm{A}$ \\
\hline \multicolumn{2}{|l|}{ Design Originator (Print/Sign) } & Date & \\
\hline
\end{tabular}




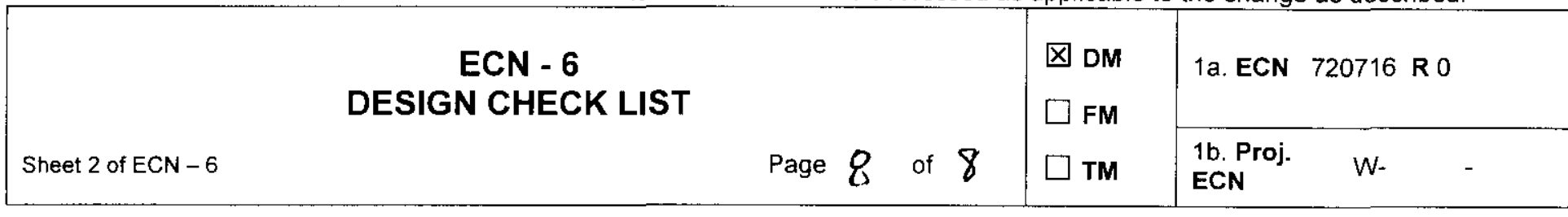

Design Check Method (Select method(s) and provide explanation of how to be performed):

\begin{tabular}{|l|l|l|}
\hline$\otimes$ Peer Check & $\square$ Design Check Team* & $\square$ Other \\
\hline
\end{tabular}

\section{Design Check Explanation:}

Theck the change for completeness, correctness and technical adequacy

'Design check team members other than the originating organization normally should consist of personnel representing: Operations, Vaintenance \& Reliability Engineering, Maintenance Management, Maintenance Crafts, Safety, and Projects.

\section{Design Check Details}

\begin{tabular}{|c|c|c|}
\hline Design inputs correctly identified? & $\not$ Yes $\square$ No $\square$ N/A & Design changes properly documented? $\$ Yes $\square$ No $\square$ N/A \\
\hline Calculations checked and are correct? & $\square$ Yes $\square$ No $\triangle$ N/A & $\begin{array}{l}\text { Test procedures reviewed and are } \\
\text { correct? }\end{array}$ \\
\hline $\begin{array}{l}\text { Design assumptions are stated and } \\
\text { verified? }\end{array}$ & $\bigotimes$ Yes $\square$ No $\square$ N/A & Is the design change adequate? \\
\hline $\begin{array}{l}\text { Design criteria incorporated into the } \\
\text { design? }\end{array}$ & $\bigotimes$ Yes $\square$ No $\square$ N/A & Is the design change complete? \\
\hline $\begin{array}{l}\text { Interfaces clearly identified in the } \\
\text { design? }\end{array}$ & $\square$ Yes $\square$ No $\backslash$ N/A & Is the design change correct? \\
\hline EQRG pre-release review required? & $\square$ Yes $\mathbf{X}_{\text {No }}$ & EQRG Pre-release Approval \\
\hline
\end{tabular}

\section{Comments:}

Reference TFC-ENG-DESIGN-P-17, Design Verification

Design Checker (Print/Sign)

Italicized text items need to be addressed. Standard text items need to be addressed as applicable to the problem/issue described. 


\section{DISTRIBUTION SHEET}

To

Distribution List

Project Title/Work Order

OSD-T-151-00007, rev. I-3, "Operating Specifications for the Double-Shell Tanks"

\begin{tabular}{|l}
\hline \\
\hline CH2M HILL Hanford Group, Inc \\
\hline P. Bosquet \\
\hline V.C. Boyles \\
\hline M.H. Brown \\
\hline J.H. Bryce \\
\hline B.K. Everett \\
\hline M.A. Fish \\
\hline J.M. Grigsby \\
\hline T.M. Horner \\
\hline C.W. Jorgensen \\
\hline L.J. Julyk \\
\hline N.W. Kirch \\
\hline M.A. Knight \\
\hline J. Lohrasbi \\
\hline D.C. Lowe \\
\hline M. Kame
\end{tabular}

T. Mackey

P.C. Miller

R.S. Nicholson

T.C. Oten

R.L. Schlosser

D. $S \cot t$

G.R. Tardiff

TSRC

J.E. Ferguson

Office of River Protection

DOE Reading Room

Engineering Standards

\section{"Operating specifications for the}

From

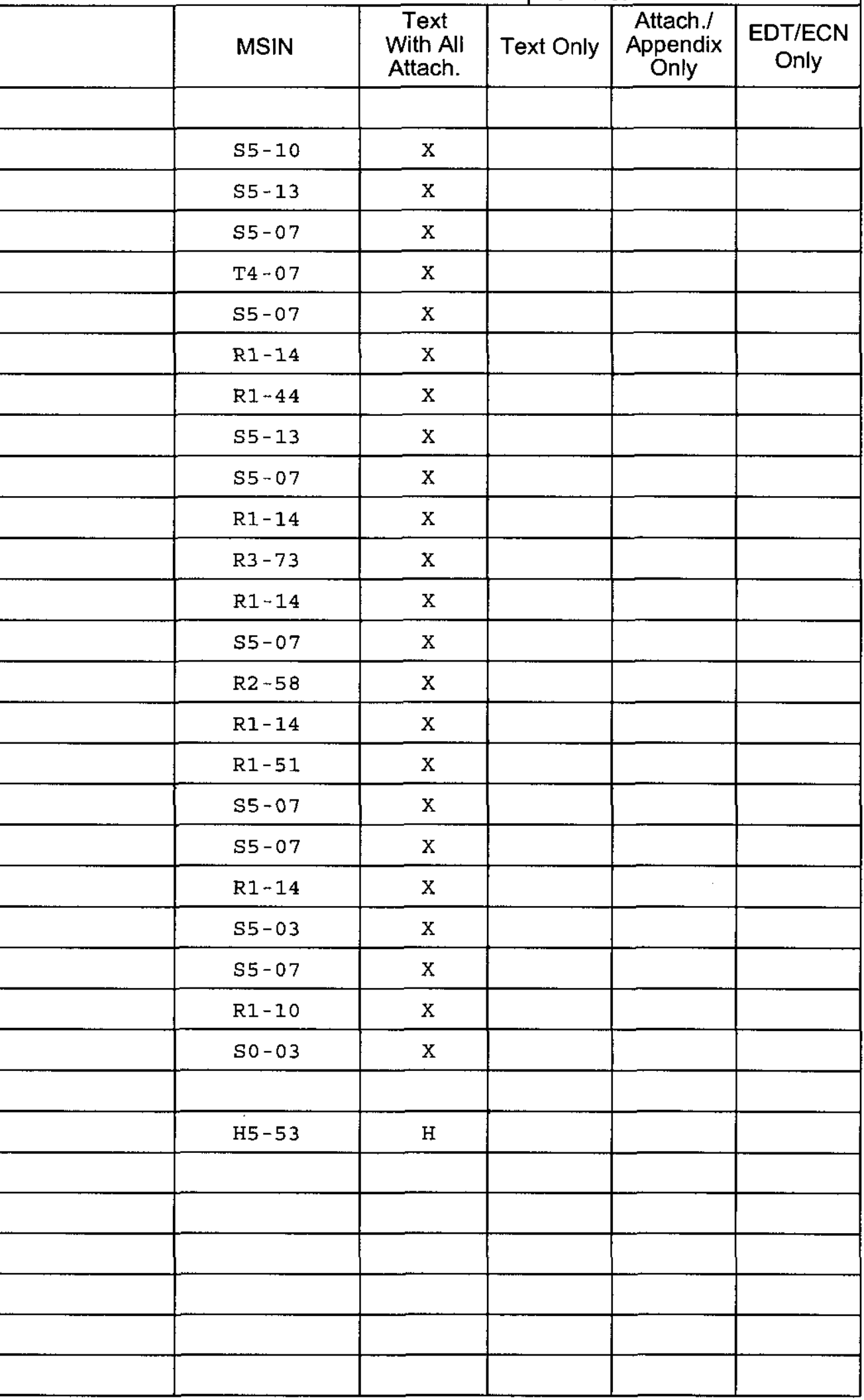

Page 1 of 1
Date $6 / 19 / 03$

EDT No. N/A

ECN No. 720716 Ro 


\title{
Technical Basis For Ventilation Requirements in Tank Farms Operating Specifications Documents
}

\author{
E.J. Berglin \\ CH2M HILL Hanford Group, Inc. \\ Richland, WA 99352 \\ U.S. Department of Energy Contract DE-AC27-99RL14047

\begin{tabular}{|c|c|c|c|}
\hline $\begin{array}{l}\text { EDT/ECN: } \\
\text { Cost Center: }\end{array}$ & $\begin{array}{l}720716 \text { Ro } \\
7 \mathrm{G} 110\end{array}$ & $\begin{array}{l}\text { UC: } 2070 \\
\text { Charge Code: }\end{array}$ & 501622 \\
\hline B\&R Code: & EW3120074 & Total Pages: & $\begin{array}{c}1786 \\
\text { cec } \\
6.23 .09\end{array}$ \\
\hline
\end{tabular}

Key Words:

OSD, DST, SST, Operating Specifications, Ventilation, HEPA, High Efficiency Particulate Air Filter

Abstract: This report provides the technical basis for high efficiency particulate air filter (HEPA) for Hanford tank farm ventilation systems (sometimes known as heating, ventilation and air conditioning [HVAC]) to support limits defined in process Engineering operating specification Documents (OSDs). This technical basis included a review of older technical basis and provides clarifications, as necessary, to technical basis limit revisions or justification.

TRADEMARK DISCLAIMER. Reference herein to any specific commercial product, process, or service by trade name, trademark, manufacturer, or otherwise, does not necessarily constitute or imply its endorsement, recommendation, or favoring by the United States Government or any agency thereof or its contractors or subcontractors.

Printed in the United States of America. To obtain copies of this document, contact: Document Control Services, P.O. Box 950, Mailstop H6-08, Richland WA 99352, Phone (509) 372-2420; Fax (509) 376-4989.

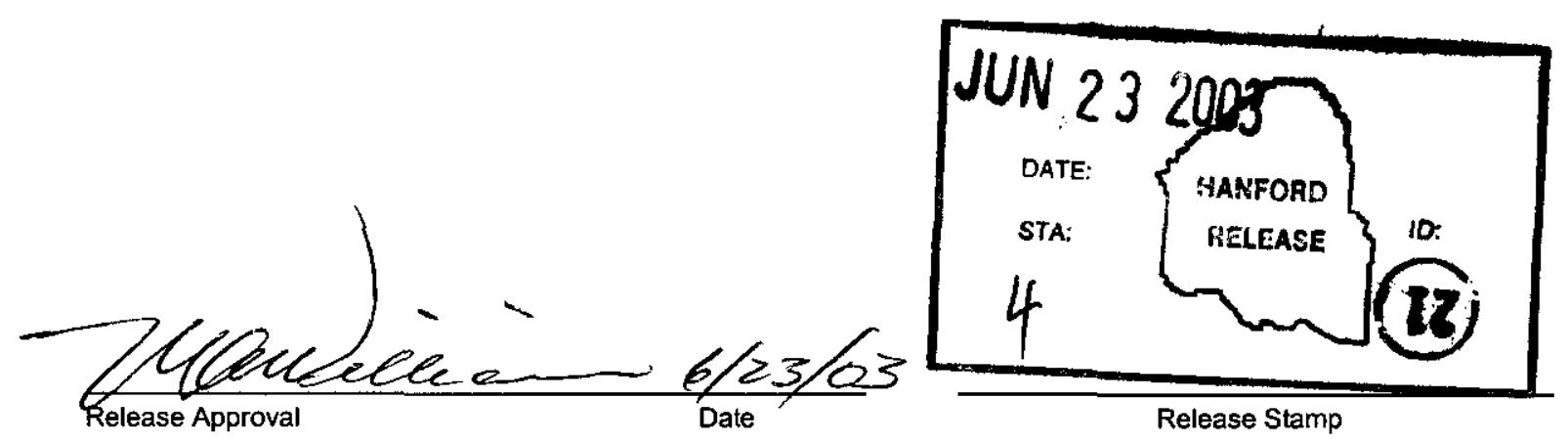

Approved For Public Release 


\section{RECORD OF REVISION}

(1) Document Number RPP -11413

Page 1

(2) Title

Technical Basis For Ventilation Requirements In Tank Farms Operating Specifications Documents

Change Control Record

\begin{tabular}{l|l} 
(3) Revision & (4) Description of Change - Replace, Add, and Delete Pages
\end{tabular}

(7)

0

Initially released $12 / 13 / 02$ on EDT 633995

1 RS Table 4.5, Section 4.4.2, 4.4.3 and 4.4.4 were changed by ECN 720716, R0.

\begin{tabular}{|c|c|c|}
\hline \multicolumn{3}{|c|}{ Authorized for Release } \\
\hline (5) Cog. Engr. & (6) Cog. Mgr. & Date \\
\hline E.J.Berglin & M.A. Knight & \\
\hline $\begin{array}{l}\text { M.H.Brown } \\
M . \lambda^{\prime} \beta^{6-14.0 S}\end{array}$ & & \\
\hline
\end{tabular}

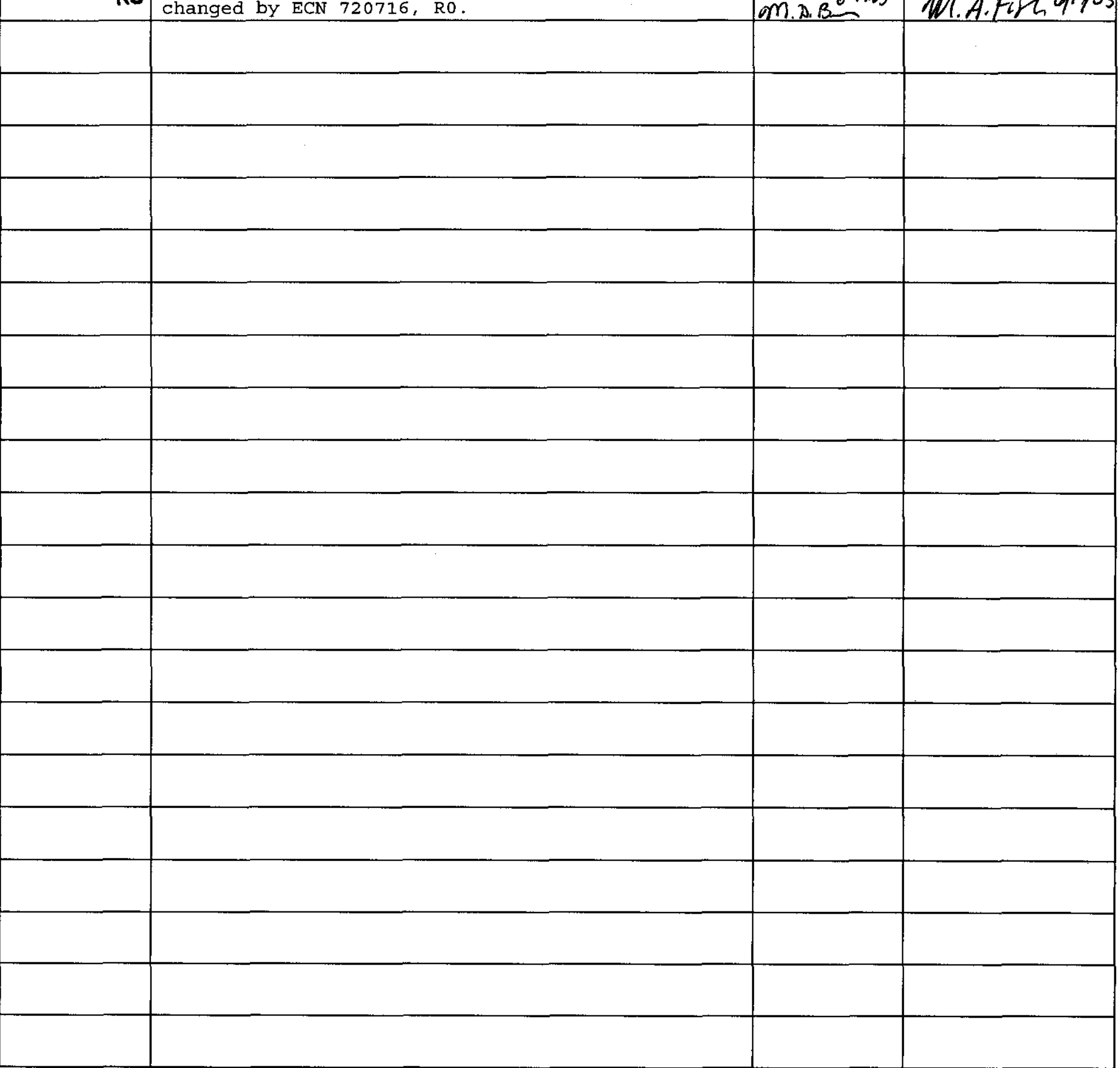


RPP-11413

Revision 1

\section{TECHNICAL BASIS FOR THE VENTILATION REQUIREMENTS CONTAINED IN TANK FARM OPERATIONAL SPECIFICATION DOCUMENTS}

E. J. Berglin

COGEMA Engineering Corporation

Date Published

June 2003

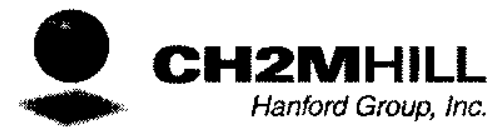

Post Office Box 1500

Richland, Washington

Prepared for the U.S. Department of Energy

Office of River Protection

Contract No. DE-AC27-99RL14047, Modification M030

Approved for Public Release; Further Dissemination Unlimited 
RPP-11413 Rev. 1

\section{EXECUTIVE SUMMARY}

This document provides an updated technical basis for tank farm ventilation systems related to Operation Specification Documents (OSDs) for double-shell tanks (DSTs), single-shell tanks (SSTs), double-contained receiver tanks (DCRTs), catch tanks, and various other miscellaneous facilities. This revision deals only with the following ventilation system operational limits:

- High Efficiency Particulate Air (HEPA) filter(s),

- Differential Pressure,

- 5.9 inches water gage (Maximum - 1st Filter in Series)

- 4.0 inches water gage (Maximum - Any Filter After First in Series)

- 1.6 inches water gage (Maximum - Breather HEPA Filter Only)

- 0.1 inches water gage (Minimum - Active Ventilation Exhaust Only)

- Temperature,

- $200^{\circ} \mathrm{F}$ (Maximum - Continuous Operation)

- $230^{\circ} \mathrm{F}$ (Maximum - Periodic Operation)

- In-Place Leak Test (formerly called Efficiency Testing)

- $0.05 \%$ Penetration/Leakage (Maximum) 
RPP-11413 Rev. 1

This page intentionally left blank.

ES-2 
TABLE OF CONTENTS

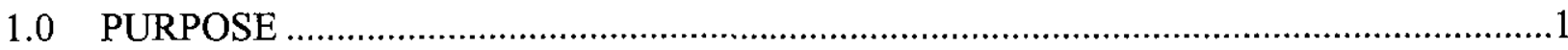

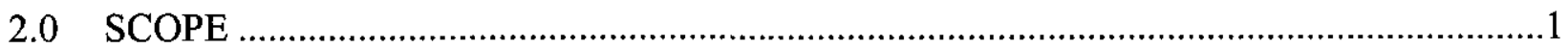

3.0 HANFORD SITE TANK FARM VENTILATION SYSTEMS BACKGROUND ................3

3.1 STANDARDS, GUIDANCE, REGULATORY, AND TECHNICAL BASIS

DOCUMENT SUMMARY .............................................................................

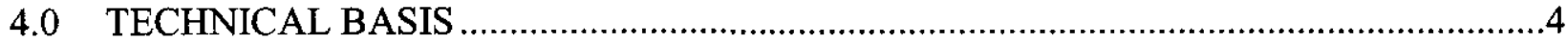

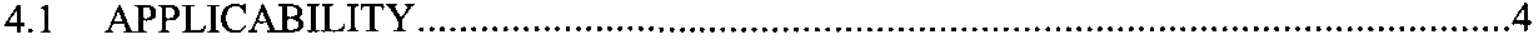

4.2 HEPA FILTER - DIFFERENTIAL PRESSURE LIMITS ........................................

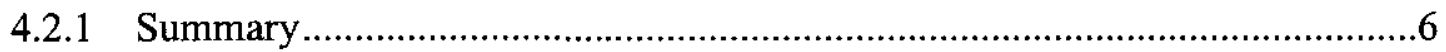

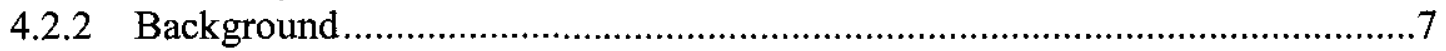

4.2.3 Basis - Maximum Differential Pressure (All HEPA Filters Except Breather

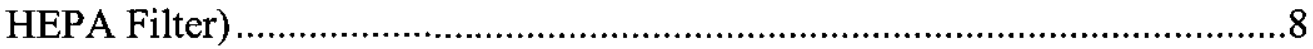

4.2.4 Basis - Maximum Differential Pressure (Breather HEPA Filter Only) ...........11

4.2.5 Basis - Minimum Differential Pressure (All Exhaust HEPA Filters on Active

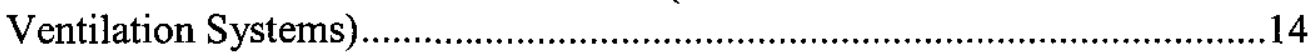

4.2.6 Basis - Differential Pressure Frequency ....................................................15

4.2.7 Related Information.........................................................................

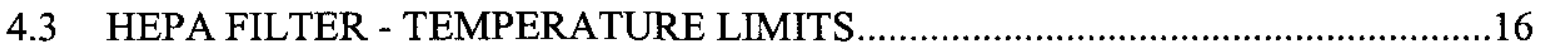

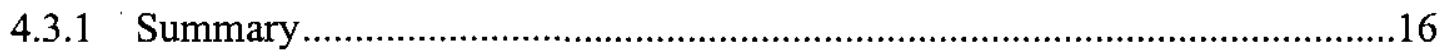

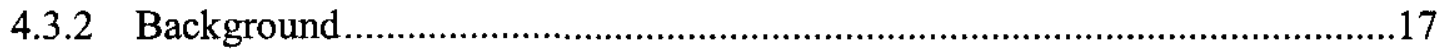

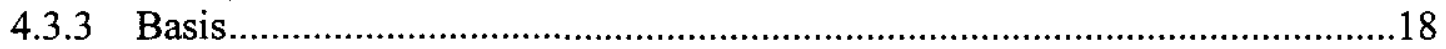

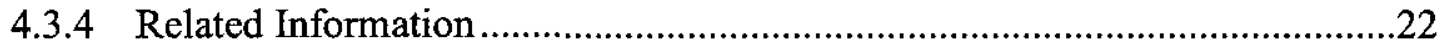

4.4 HEPA FILTER - IN-PLACE LEAK TEST CRITERIA …………………............24

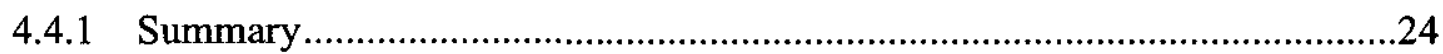

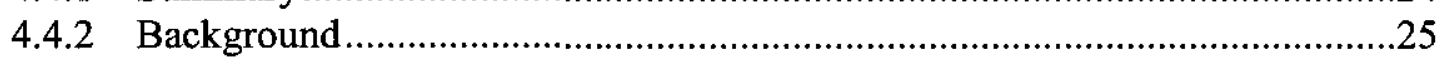

4.4.3 Basis - In-Place Leak Test ..................................................................27

4.4.4 Basis - In-Place Leak Test Frequency …………........................................28

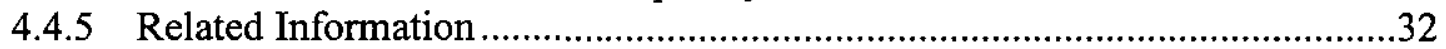

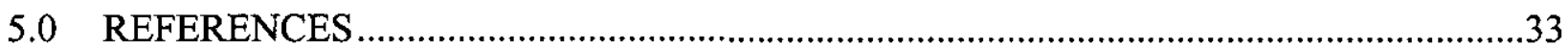

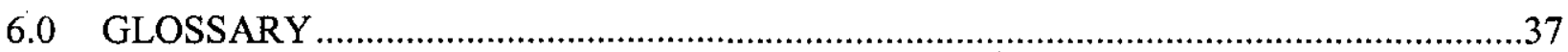


RPP-11413 Rev. 1

\section{APPENDICES}

A GENERAL DESCRIPTION OF TANK FARM VENTILATION SYSTEMS (ACTIVE AND PASSIVE).

B HEPA FILTRATION DETAILS OF TANK FARM VENTILATION SYSTEMS

C STANDARDS AND GUIDANCE DOCUMENTS

D HEPA FILTER DIFFERENTIAL PRESSURE RELATIONSHIPS D-1

E DISCUSSION NOTES RELATED TO HEPA FILTERS WITH FLANDERS FILTERS, INC., JUNE - AUGUST 2002

F DISCUSSIONS ON BREATHER FILTERS WITH HANFORD SITE ENGINEERING STAFF, JULY 2002

G FLANDERS FILTERS INC. BULLETIN NO. 936D, NUCLEAR GRADE HEPA FILTERS.

H FLANDERS FILTERS, INC. LETTERS RELATED TO HEPA FILTER TEMPERATURE LIMITS BASED ON HEPA FILTER MATERIALS.

I MAXIMUM TEMPERATURES FROM TMACS FOR TANK FARM TANKS

J DOE CHALLENGE AEROSOL DOCUMENTS SUPPORTING EMORY 3004 FOR THE HANFORD SITE.

K VENTILATION DISCUSSIONWITH HANFORD SITE ENGINEERING STAFF $\mathrm{K}-1$

L HANFORD SITE TANK FARM VENTILATION DISCUSSIONS WITH HANFORD SITE TANK FARM ENGINEERING.

M OLDER TECHNICAL BASIS LETTERS FROM WHC-SD-TI-008 M-1

N BREATHER FILTER BASIS FROM WHC-SD-WM-TI-352. N-1

O TEMPERATURE DATA FOR NEOPRENE - DUPONT/DOW . $0-1$ 


\section{LIST OF TABLES}

Table 4-1. Differential Pressure Drop (Maximum) Across HEPA Filters...................................... 6

Table 4-2. Frequency of Differential Pressure Measurement For HEPA Filters............................ 6

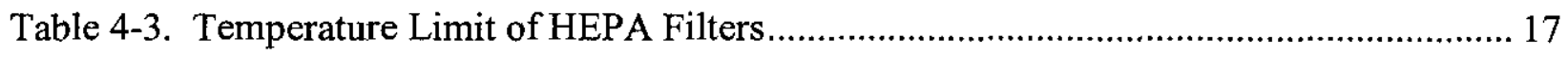

Table 4-4. Temperature Limits of Various HEPA Filter Materials - Continuous Operation...... 20

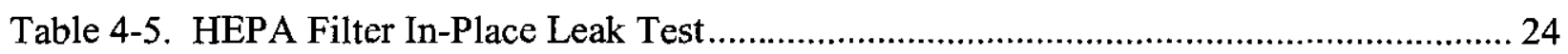

\section{LIST OF TERMS}

\begin{tabular}{|c|c|}
\hline $\mathrm{AC}$ & Administrative Control \\
\hline ALARA & as low as reasonably achievable \\
\hline ASME & American Society of Mechanical Engineers \\
\hline AWF & Aging Waste Facility \\
\hline CAM & continuous air monitoring \\
\hline $\mathrm{cfm}$ & cubic feet per minute \\
\hline CFR & Code of Federal Regulations \\
\hline DCRT & Double-Contained Receiver Tank \\
\hline DNFSB & Defense Nuclear Facilities Safety Board \\
\hline DOE & U.S. Department of Energy \\
\hline DOP & dioctyl phthalate \\
\hline DOS & Di-2-ethylhexyl sebacate \\
\hline DST & double-shell tank \\
\hline ERDA & U.S. Energy Research and Development Administration \\
\hline FSAR & Final Safety Analysis Report \\
\hline HEGA & High Efficiency Gas Adsorber \\
\hline HEPA & High Efficiency Particulate Air \\
\hline HEME & High Efficiency Mist Eliminator \\
\hline $\begin{array}{l}\text { HVAC } \\
\text { in. }\end{array}$ & $\begin{array}{l}\text { Heating, Ventilation, and Air Conditioning } \\
\text { inch(es) }\end{array}$ \\
\hline $\mathrm{kPa}$ & kiloPascals \\
\hline $\mathrm{msec}$ & millisecond \\
\hline NA & Not Applicable \\
\hline NMD & Nominal Mean Diameter (of particles) \\
\hline NNSA/DP & National Nuclear Security Administration/Defense Programs \\
\hline NOC & Notice of Construction \\
\hline OSD & Operation Specification Document \\
\hline
\end{tabular}




\section{LIST OF TERMS, Continued}

$\begin{array}{ll}\text { Pa } & \text { Pascals } \\ \text { psi } & \text { pounds per square inch } \\ \text { RTV } & \text { Room Temperature Vulcanizing } \\ \text { SST } & \text { Single-Shell Tank } \\ \text { TMACS } & \text { Tank Monitoring And Control System } \\ \text { TSR } & \text { Technical Safety Requirement } \\ \text { WAC } & \text { Washington Administrative Code } \\ \text { w.g. } & \text { water gage } \\ \text { WDOH } & \text { Washington State Department of Health } \\ \% & \text { percent } \\ { }^{\circ} \mathrm{F} & \text { degrees Fahrenheit }\end{array}$




\subsection{PURPOSE}

This document presents the results of a technical basis review and update related to the Hanford Site tank farm ventilation facilities. These results are intended to provide the basis for information to upgrade the Hanford Site tank farms Operation Specification Documents (OSDs), address deficiencies documented in an internal Hanford Site audit (Lowe 2001), and speaks to some of the deficiencies noted in a May / June 2000 review (DNFSB/TECH-23) by the Defense Nuclear Facility Safety Board (DNFSB).

\subsection{SCOPE}

This document is intended to provide the technical basis for some of the ventilation specifications given in the Tank Farm OSDs. The following is a listing of the effected facilities and the OSD number followed in []:

- Double-Shell Storage Tanks (DST) [OSD-151-T-00007];

- 204-AR Waste Unloading Facility [OSD-151-T-00008];

- Active Double-Contained Receiver Tanks [OSD-151-T-00011];

- Single-Shell Waste Storage Tanks (SSTs) [OSD-151-T-00013];

- Miscellaneous Facilities [OSD-151-T-00015] that include the following facilities and ventilation equipment:

- 244-AR Vault,

- 244-CR Vault,

- 244-U Facility,

- 242-S Evaporator Facility,

- 242-T Evaporator Facility,

- Catch Tanks,

- Portable Exhausters,

- SX Sludge Cooler,

$\circ$

- 244-A Facility, and

- Breather Filters

- 241-AZ 702 Vessel Ventilation System [OSD-151-T-00019]. 
Only the specification limits related to the following are included:

- High efficiency particulate air (HEPA) filter limits to protect against filter degradation or failure:
- Differential pressure,
- Temperature, and
○ In-place Leak Test.

In the Hanford Site tank farm ventilation systems, the primary device related to operation specifications upgrade is the HEPA filtration and its related devices. The HEPA filter is most important because it is the primary abatement technology for removal of radioactive airborne particulate from air emission sources at Hanford Site Tanks Farms.

All values used for the HEPA filters in this initial release have been used in previous OSD documents and associated technical basis. The technical basis for the temperature and In-place Leak test values has been improved by additional information and references. However, the technical basis for the HEPA differential pressure values is still not fully developed. As this document is intended to be a living document, it will be revised and updated as information becomes available. 


\subsection{HANFORD SITE TANK FARM VENTILATION SYSTEMS BACKGROUND}

An overview of Hanford Site tank farm ventilation systems to include active and passive ventilation, is described in Appendix A.

Details on the HEPA filtration portion of the Hanford Site tank farm ventilation systems are given in Appendix B. References to a "Breather Filter" in this document refer to a specialized passive ventilation HEPA filter system with an integral liquid seal loop designed for pressure relief of the ventilated space.

\subsection{STANDARDS, GUIDANCE, REGULATORY, AND TECHNICAL BASIS DOCUMENT SUMMARY}

The Hanford Site tank farm ventilation systems are governed by a number of standards, regulations, controls, bases, and guidance documents in three key areas - Safety, Environmental, and Engineering. This technical basis document focuses primarily on the Engineering portion of the tank farm ventilation systems but references the Safety and Environmental areas where applicable. Safety and Environmental regulations are dynamic in nature. The reader is advised to review regulatory documents for the latest changes.

For the Hanford Site tank farm ventilation operations, a summary of the governing standards, regulations, controls, bases, and guidance documents are listed in Appendix C. These governing documents sometimes have conflicting or incomplete information, primarily because many of these documents have not been recently updated. Some of these documents are over 25 years old. For HEPA filtration, the DNFSB has noted some conformance deficiencies by U.S. Department of Energy (DOE) related to some of these governing documents; however, the $\mathrm{DOE}$ is in the process of corrective action as described in Appendix C.

The basic design, function, and testing of the ventilation systems and related HEPA filtration systems have not changed significantly over the years. These documents can still be used; however, some additional explanation may be required to resolve conflicting or incomplete information. This technical basis intends to address the conflicting or incomplete information as applicable to define the specification requirements for OSDs.

Some of the recent documents related to the HEPA filtration technical bases in this document are as follows:

- 7G000-01-019, Engineering Standard For Design, Procurement, Construction, and Acceptance Of Tank Farm Radioactive Air Emission Units (Gustavson 2001);

- DOE/ORP-2000-20, Assessment of Potential Vulnerability Due To Degraded High-Efficiency Particulate Air (HEPA) Filters in Nuclear Facilities;

- RPP-12401, Technical Justification For Operating Tank 241-C-103 Breather Filter in Excess of Rated Flow (Gustavson 2002); 
- RPP-6804, Setpoint Calculations For Delta P-Interlocks (Nickolaus 2000);

- RPP-6331, HEPA Filter Vulnerability Assessment (Gustavson 2000a); and

- RPP-5594, Evaluation of Alternative Control for Prevention and/or Mitigation of HEPA Filter Failure Accidents at Tank Farm Facilities (Gustavson 2000b).

- TFC-ENG-STD-C-07, Management Of HEPA Filter Systems (TFC-ENG-STD-C-07)

\subsection{TECHNICAL BASIS}

\subsection{APPLICABILITY}

The specification limits defined by this technical basis are applicable for all Tank Farm ventilation systems discussed in the scope of this document or as referenced by other documents and is intended to:

- Protect equipment from damage

- Ensure product/service quality

- Increase efficiency

- Prevent mission interruption.

For a given process/operation parameter, a specification limit generally includes one or two of the following:

- Design limit to maintain the process/operation within its domain defined by documents such as structural analyses, manufacturer or design specification,

- Normal operating limit to maintain the process/operation:

○ within its design limit with adequate margin of safety or

- inside a range known to provide the best conditions of operation, based on experience, test, calculations

A particular system or component may have more restrictive limitations than the specification limits stated in this document. These other limitations may include physical operating limitations of a particular system or system component, regulatory and environmental limits, limits based on operational experience and maintenance requirements, and other requirements from sources outside of the scope of this document. These more restrictive limitations may be covered by a variety of sources that could include individual system OSDs and associated technical basis, operating procedures, operating round sheets, etc. These specification limits are intended to be set within the boundaries of associated safety and environmental limits; however, with continuously changing requirements, these other limits should always be checked for more restrictive requirements.

More restrictive limits than defined in this document may come from a variety of sources that could include: 
- overall ventilation system (for example, a ventilation system may not be capable of generating a differential pressure as high or higher than the specification limit),

- ventilation system components (for example a HEGA, HEME, condenser may have a more restrictive limit than the HEPA),

- structural (maintaining the structural integrity of a tank)

- emission confinement control (maintaining a vacuum on the tank)

- environmental / regulatory (for example, overall system flow rate may be dictated by stack emission that may sequentially limit other parameters such as differential pressures),

- maintenance limits, most likely based on operational experience, for HEPA filter change out.

In all cases, the actual system or component is restricted by the most limiting value. 


\subsection{HEPA FILTER - DIFFERENTIAL PRESSURE LIMITS}

\subsubsection{Summary}

Table 4-1 summarizes the differential pressure limit requirements for the tank farm ventilation systems.

Table 4-1. Differential Pressure Drop (Maximum) Across HEPA Filters

\begin{tabular}{|c|c|c|c|}
\hline HEPA Filter Type - Configuration & Maximum & Minimum & Comments \\
\hline Inlet Filter - First in Series & 5.9 in. w.g. & NA & See note(s): 1,2 \\
\hline $\begin{array}{l}\text { Inlet Filter - Any Filters In Series } \\
\text { After First Filter }\end{array}$ & 4.0 in. w.g. & NA & See note(s): 1,2 \\
\hline $\begin{array}{l}\text { Inlet Filter(s) - Multiple Filters in } \\
\text { Series (Overall) }\end{array}$ & 5.9 in. w.g. & NA & See note(s): 3 \\
\hline Exhaust Filter - First in Series & 5.9 in. w.g. & 0.1 in. w.g. & See note(s): $1,2,4$ \\
\hline $\begin{array}{l}\text { Exhaust Filter(s) - Any Filters In } \\
\text { Series After First Filter }\end{array}$ & 4.0 in. w.g. & 0.1 in. w.g. & See note(s): $1,2,4$ \\
\hline $\begin{array}{l}\text { Exhaust Filter(s) - Multiple Filters } \\
\text { in Series (Overali) }\end{array}$ & 5.9 in. w.g. & 0.1 in. w.g. & See note(s): 3,4 \\
\hline Breather Filter(s) & $\begin{array}{l}1.6 \text { in. w.g. } \\
\text { (at rated flow) }\end{array}$ & NA & See note(s): 1,5 \\
\hline
\end{tabular}

Notes:

Definitions:

- Differential pressure - The drop in pressure across a filter (or series of filters); inlet to exhaust on active ventilation systems.

- HEPA filter (defined for test instrument setup below) - Along the air stream path, a single HEPA filter (or bank of filters) at one location. For testing purposes, system configuration / test instrument setup may include secondary filter (i.e., pre filters, etc).

- NA = not applicable

(1) Limit applies to each HEPA filter.

(2) Limit applies to each HEPA filter if instrument setup allows, otherwise, limit for multiple HEPA filters in series applies.

(3) Required if multiple HEPA filters cannot be measured individually', otherwise, optional.

(4) Minimum value only applies to active ventilation systems (forced air). This does not apply to HEPA filters with very low flow rates where the differential pressure of a new / clean filter at ventilation system operational flow rate may be close to the minimum value.

(5) Differential pressure is checked during In-place Leak testing. The differential pressure value of $1.6 \mathrm{in}$. w.g. is based on maximum filter flow rating of $160 \mathrm{cfm}$. Differential pressure limit $\left(\mathrm{D}_{\mathrm{b}}\right)$ value shall be adjusted to the In-place Leak test flow rate by the following formula:

$D_{b}$ (in. w.g.) $=($ Test flow rate in $\mathrm{cfm} / 100)$

For example, if the test flow rate is $100 \mathrm{cfm}$, then the maximum allowable measured filter differential pressure is $1.0 \mathrm{in.}$ w.g.

Table 4-2. Frequency of Differential Pressure Measurement For HEPA Filters 


\begin{tabular}{|l|l|}
\hline Ventilation System Configuration & Minimum Frequency \\
\hline Active and Operating & Once daily \\
\hline $\begin{array}{l}\text { All Others - Includes Passive /Breather } \\
\text { Filters }\end{array}$ & When In-Place Leak Test is performed. \\
\hline
\end{tabular}

Differential pressure limits summarized in this document are based on information from the following documents:

- RPP-5594, Evaluation of Alternative Control For Prevention and/or Mitigation of HEPA Filter Failure Accidents At Tank Farm Facilities (Gustavson 2000b);

- RPP-6804, Setpoint Calculations For Delta-P Interlocks (Nickolaus 2000);

- Rockwell Hanford Operations internal letter 65260-80-0905 (Ehli 1980) (see Appendix M); and

- Discussions with Hanford Site Tank Farm Engineering staff. (See supporting notes in Appendix F, Appendix K, and Appendix L.)

\subsubsection{Background}

Excessive differential pressure across a filter will cause the filter to rupture. This is a filter failure. The differential pressure across a filter increases as it traps particles. Some of these particles may be contaminated. This particle trapping is also referred to as filter loading. On active ventilation systems, the fan speed may be increased to overcome the increase in differential pressure (resistance) of a filter while maintaining the same air flow rate.

Specification limits were chosen to maintain a safety margin against HEPA filter failure based on continuous operation. For short periods of time, many of these operational limits may be exceeded without damage to the filter but need to be evaluated on an individual basis. The HEPA filter differential pressure specification limits in this section are to protect the HEPA filter from pressure failure. Some of the operating parameters used in the determination of these limits (such as flow rate) at a minimum will meet, but most likely exceed, the specific individual system operating limits (see previous discussion in Section 4.1, Applicability).

\subsubsection{Differential Pressure Relationships}

The hierarchy of differential pressure relationships (American Society of Mechanical Engineers [ASME] N509 [ASME 1989a], Section 4.6 and Definitions) related to filters is defined as follows (lowest to highest).

- Operating differential pressure (clean filter) - Minimum: approximately 0.5 to $0.8 \mathrm{in}$. w.g. depending on filter model (at manufacturer's rated flow);

- Operating differential pressure (clean filter)-Maximum: 1.0 or 1.3 in. w.g., depending on filter model (at manufacturer's rated flow); 
- Operating differential pressure - Normal: Between minimum and maximum operating limits;

- Operating differential pressure-Maximum: 5.9 in. w.g.;

- Maximum design differential pressure (Test Pressure*): 10 in. w.g.; and

- Structural design differential pressure: exceeds 10 in. w.g.; suggested ranges include 11 to 28 in. w.g.

* HEPA Test Pressure, AG-1 (ASME 1997) Table FC-5140-3, also referred to as maximum rated pressure or pressure rating.

The bases for these differential pressure relationships that support these differential pressure limits are discussed in Appendix D.

The basis for the maximum operating differential pressure values basis are also influenced by the following:

- Vacuum limits on most of the large Hanford tanks under specific tank level conditions are currently 6 in. w.g.

- HEPA filter limit of 8.0 in. w.g. suggested by the ERDA 76-21 (ERDA 1976, Section 3.2.4) for used filters to allow for decreased filter strength due to aging and deteriorations.

\subsubsection{Basis - Maximum Differential Pressure (All HEPA Filters Except Breather HEPA Filter)}

These maximum differential pressure specification limits are not absolute as the actual limit values are arbitrary selected within a range of operational values. However the limit values were selected based on a combination of acceptable ranges within standards and guidance documents, good engineering judgment, and historical operating experience at Hanford. An acceptable range for the maximum HEPA filter differential pressure spans from within the acceptable range for a new clean filter to less than or equal to the maximum design pressure (10.0 in. w.g at rated flow). The current specification limits in this section have been arbitrarily chosen within the acceptable range to conform with current Hanford values, to minimize system changes, and to provide a consistent value for use by operations. Further refinement (e.g., specific to various ventilation systems) of these limits within the acceptable range may occur upon more review of Tank Farm operational requirements.

It has been observed that HEPA filter systems operating in Hanford Site tank farm applications tend to "load up" relatively slow until a pressure drop of 2 to 3 in. w.g. is reached; further pressure drop increases take place much faster. HEPA filter change out is normally initiated when the pressure drop approaches $3.0 \mathrm{in}$. w.g. However, HEPA filter change out and initiation levels may vary for specific filters base on filter loading rate, operational requirements, system configuration, and maintenance scheduling. Filter differential pressure surveillance data is verified to be within limits by Operations, and it is tracked and trended by Engineering. 
The specification limits for differential pressure defined in this document are to protect the HEPA filter from failure by providing adequate margin of safety from the HEPA maximum design limit differential pressure of $10 \mathrm{in}$. w.g. The highest maximum limit (5.9 in. w.g.) on the first filter of the inlet or exhaust train has been historically proven at Hanford to provide adequate time for filter change out before the HEPA maximum design limit is reached. For multiple HEPA filters in a train, the downstream filter(s) load up slowly because the majority of the filtration is provided by the first filter in the filter train. A lower maximum limit (4.0 in. w.g.) is set for the downstream filter(s) in the ventilation exhaust filter train, because if the first exhaust filter fails, the downstream exhaust filter(s) are the only remaining barrier to the atmosphere (Ehli 1980, Appendix M).

The two maximum specification limits are within or near the suggested operating pressure limit range of 4.0 to $5.0 \mathrm{in}$. w.g. for filter change out suggested in the following sources:

- "HEPA filters shall be replaced when the pressure drop across the filter exceeds 5 inches water gage. Remotely installed HEPA filters shall be replaced when the pressure drop across the filter exceeds 5 inches water gage." (HNF-RD-8703, p 21, item 10, Section 4.6, "Abatement Technology - Emissions Filtration and Treatment.")

- "At many ERDA facilities, HEPA filters are operated routinely to pressure drops as high as 4 to $5 \mathrm{in}$. w.g. Figure 2.5 shows the effect of such operation on filter life and maintenance costs." "Although investment and power costs will be lower for the system operated to 2 in. w.g. pressure drop, the total annual cost of owning the system, including materials and labor costs for filter replacement, may be less for the system in which HEPA filters are replaced at pressure drops on the order of 4 to 5 in. w.g. Total savings for the facility as a whole may be even greater when the reduced interruption of building operations due to the reduced frequency of filter change is taken into consideration." (ERDA 1976, Section 2.3.5)

In summary, these maximum specification limits incorporates the following features:

- Maintains an adequate margin of safety with the maximum design limit (10 in. w.g.),

- Provides adequate time for filter change out (typically change out on Hanford Site tank farms is initiated in the range of 2 to 5 in. w.g.), and

- Provides a consistent limit for these type of filters that has been successfully proven in Hanford Site use by more than 20 years of experience.

\subsubsection{Maximum Operating Limit - 5.9 inches water gage}

This Maximum Operating Limit, 5.9 inches water gage, applies to all HEPA filter(s) with high loading potential. For Hanford Site tank farm operations, the HEPA filters with highest loading potential are the first stage of HEPA filtration on the exhaust train of an active ventilation system because it is the first line of defense for contaminates from the tanks. The first stage of HEPA filtration on an inlet filter train of an active ventilation system also has high loading potential due to its exposure to outside environment that may include dust, smoke, cold weather, high 
humidity, and possible frosting on the filter. This limit is set 40 percent below the "maximum design pressure" limit of $10 \mathrm{in}$. w.g. for added safety margin on filter failure and 20 percent less than the HEPA filter limit of 8.0 in. w.g. suggested by the ERDA 76-21 (ERDA 1976, Section 3.2.4) for used filters to allow for decreased filter strength due to aging and deteriorations.

This differential pressure limit applies to the first stage of HEPA filtration on both the inlet and exhaust filter trains of an active ventilation system because these filters, being the first in line, will trap most of the material in the air stream, therefore, loading up significantly faster than the "downstream" filters. Likewise, for a series of HEPA filters in a train where the differential pressure is measured across all the HEPA filters in the series, the same limit applies. For multiple filters in a series, the same maximum limit (e.g., 5.9 in. w.g) as the first HEPA filter applies because 1) the first HEPA filter typically dominates the pressure drop as it loads up first (nominally passing 0.05 percent of the particles in the range of the test aerosol through to the next filter in series or 2) it is assumed that only one filter is experiencing all the pressure drop, a conservative approach, since the pressure drop of each HEPA filter may not be able to be individually measured.

Historically, at the Hanford Site, the 5.9 in. w.g. limit appears to be partially based on the AW Tank Farm ventilation system (Ehli 1980, Appendix M) operating conditions to maintain a negative pressure on the AW tanks. As stated in the reference, "The total pressure drop across the filters in a series is limited to 5.9 in. w.g. to ensure that a vacuum is maintained on the tank. The primary tank exhaust fan" ... "is incapable of pulling a vacuum greater than 5.9 in. w.g." ... "Therefore, a total pressure drop greater than 5.9 in. w.g. will mean the tank is not under vacuum." It then appears that the $5.9 \mathrm{in}$. w.g. was used on other tank farm ventilation system, based on AW Tank Farm. One speculated reason this basis was used on other tanks is that AW Tank Farm was deemed to be a "worst case" condition (e.g., lowest fan static pressure) for all tank farm exhausters and therefore this limit could be used all tanks as it would be conservative.

Another speculated basis for the Hanford 5.9 in. w.g. limit may be related to the structural design of the Hanford's double shell tanks (DSTs). On these tanks, a 6.0 in. w.g. maximum tank vacuum differential pressure operating limit is maintained by either ventilation limits or liquid level in the tanks to prevent the tank bottom from uplifting. Originally, limiting the combined HEPA filters to a maximum differential pressure of 5.9 in. w.g. may have assured the DSTs vapor space would never reach the 6.0 in. w.g. vacuum tank limit. Other exhaust system pressure losses, combined with the HEPA filter differential pressure, provide additional factor of safety against reaching the tank vacuum limit.

The newest upgraded active ventilation system in the Hanford Site tank farms, AZ-702, uses a HEPA filter maximum operational differential pressure value of $6.0 \mathrm{in.}$ w.g. As stated in HNFSD-RE-TI-223, Revision 1 (p. 6, Section 2.5, "High Efficiency Particulate Air [HEPA] Filters [AZ-K1-4-1]"):

"Differential Pressure Across Any Filter - Specification Limit $<=6.0$ inches water gage (w.g.) (OSD-T-151-00019)....If the differential pressure across a HEPA filter becomes excessive, the filter will rupture and release radionuclides to the atmosphere. An OSD 
limit of 6.0 in. w.g. was set below the manufacturer's design limit of $10 \mathrm{in.}$ w.g. for the protection of the filter media (see Attachment 4, Flanders/CSC Facsimile Message/Transmittal)."

To be consistent with other tank farm ventilation systems, the specification limit for the AZ-702 system will be changed to 5.9 in. w.g in the next revision (OSD-T-151-00019).

\subsubsection{Maximum Operating Limit: 4.0 inches water gage}

The Maximum Operating Limit, 4.0 in. w.g., applies to any HEPA filtration stage in the ventilation system inlet or exhaust train, after the first HEPA filtration stage (i.e., secondary filters). This limit is set 33 percent below the first HEPA filter in a series (i.e., primary filter) because secondary filters do not load up as fast because the primary HEPA filters are stopping nominally 99.95 percent of the particles (or inversely only passing 0.05 percent of the particles) of the size in the range of the In-Place Leak Test challenge aerosol. In a filter train, all HEPA filters (i.e., secondary filters) after the first HEPA filter stage (i.e., primary filter), under normal operating conditions, it will load up much slower than the first stage HEPA filter. A fast or high loading of secondary HEPA filter stages indicates failure in the first HEPA filter stage or unusual particle loading in which case earlier warning than the first HEPA filter stage is warranted. Since any secondary HEPA filter(s) on the exhaust train are typically the last barrier to confinement before the exhaust stack and atmosphere, this limit has been set below that of the first / primary HEPA filter in the exhaust train and at the conservative end of the HEPA filter change out range (based on differential pressures) of 4 to 5 in. w.g. suggested in EDRA 76-21 (EDRA 1976), Section 2.3.5.

\subsubsection{Basis - Maximum Differential Pressure (Breather HEPA Filter Only)}

The maximum pressure specification limit for the HEPA breather filter application for Hanford tank farms has a minimal technical basis but is supported by a combination of good engineering judgment and historical operating experience at Hanford. An "industry standard" related to differential pressure for HEPA filter change out has a minor applicability in this application and therefore has been used as a good starting point until more technical review of this limit can be done. This specification limit conforms with the current Hanford value, minimizes system changes, and provides a consistent value for use by operations. Further refinement of this limit may occur in the future.

The HEPA breather filter as defined for Hanford tank farm applications is a unique, specific assembly consisting of a tank ventilation air pipe, HEPA filter with filter housing, tank pressure relief seal loop, differential pressure gauge, and isolation valve. The seal loop pressure relief, set at approximately 4.0 in. w.g., works passively and limits the maximum pressure or vacuum applied to the tank and subsequently the tank's associated HEPA breather filter(s).

HEPA breather filters used in the Hanford tank farm application are a passive ventilation system used to equalize pressure variations between a waste tank's interior pressure and the environment (atmospheric pressure). These filters typically do not have a constant set flow rate and, in fact, 
allow flow through the filter in both directions depending on outside ambient atmospheric conditions relative to in-tank conditions. HEPA breather filters have historically been nominally rated at $160 \mathrm{cfm}$ by the manufacturer, however, these same filters have been recently upgraded to $200 \mathrm{cfm}$ with a corresponding linear increase in differential pressure (see Appendix G, 11 " Pureform filter Element, CC-F, page G-12).

Used in a Hanford tank farm passive ventilation system application, these filters typically operate at very low flow rates resulting in very slow loading. As the filter loads up, the differential pressure increases. Because most Hanford tanks have ventilation leakages through other minor unfiltered pathways, it is desirable to maintain a low filter flow resistance (i.e. low differential pressure) to preferentially channel flow through the HEPA breather filter instead of through the other unfiltered leakage paths.

\subsubsection{Maximum Operating Limit: 1.6 inches water gage (Breather Filters)}

The Maximum Operating Limit for Hanford Site tanks using breather filters (HEPA filters with seal loops) for tank venting as a passive ventilation system is $1.6 \mathrm{in}$. w.g. This specification limit has been set at 100 percent over manufacturer's typical minimum limit for a new "clean" filter of $0.8 \mathrm{in}$. w.g. at rated flow of $160 \mathrm{cfm}$. This allows some operating margin from a new, clean HEPA while at the same time is not overly constrictive to allow it to function as pressure equalization between the tank and outside air environment (see Appendix N).

Per discussions with Flanders Filters Inc. (see Appendix E), "The industry rule of thumb is to replace the filter when the pressure drop doubles from that of the "clean" filters (i.e., new installed). However, it should be recognized that 80 percent of the industry applies to "clean rooms" that operate in a very clean environment and, therefore, do not "load up" quickly ." Discussions with Hanford Site engineering staff (see Appendix F) indicate that Hanford Site tank farm operating experience with HEPA breather filters under current operation condition are:

- Filters are not loading up significantly,

- Filters are operating at a very low flow rate,

- In-place leak testing is done annually on most breather filters based on historical review of Hanford Site breather filter testing and associated consequences of breather filter failures (see WHC-SD-WM-ES-270), and

- The seal loop pressure relief set in the range of 4 to 6 in. w.g. limits the maximum differential pressure the tank and associated breather HEPA filter can experience.

The differential pressure of these breather filters is only measured during the periodic In-place Leak testing. During In-place Leak testing, a portable fan generates the air flow to perform the aerosol testing with a nominal flow rate of $40-50 \mathrm{~cm}$. It is not possible to suspend test aerosols sufficiently at the low passive breathing operating flows. The full air flow ranges allowed during In-place Leak testing starts extends from 20 or $35 \mathrm{cfm}$, depending on the system, to a high flow value of $100 \mathrm{cfm}$. The differential pressure specification limit is based on maximum rated flow instead of rated flow because these passive systems do not have a 
RPP-11413 Rev. 1

"constant" design pressure. To compensate for the variable In-place Leak test flow rates, the specification limit is based on the breather filter's maximum rated flow $(160 \mathrm{cfm})$ and adjusted relative to the In-place Leak test flow rate.

In the laminar flow rate ranges of the In-place Leak testing, the relationship between flow rate and differential pressure is linear. Adjusting the differential pressure value based on In-place Leak test flow rate creates a consistent "level of loading" for all filters and test conditions The general formula for adjusting the breather filter differential pressure specification limit is as follows:

Differential Pressure Limit (in. w.g. $)=(($ Test flow rate in $\mathrm{cfm}) *(1.6$ in. w.g./ $/ 60 \mathrm{cfm})$ $=($ Test flow rate in $\mathrm{cfm} / 100)$

For example, at a nominal In-place Leak test flow rate of $50 \mathrm{cfm}$, the corresponding differential pressure limit would be 0.5 in. w.g.

The recent change in maximum flow rating of the breather filter is not due to a change in design of the filter, but allowing a 25 percent increase in differential pressure ( 0.8 to $1.0 \mathrm{in}$. W.g.) for a corresponding 25 percent increase in flow rate $(160$ to $200 \mathrm{cfm})$. Because the linear relationship is maintained between flow rate and differential pressure, the above formula is applicable to both ratings. The lower breather filter rating of $160 \mathrm{cfm}$ has been used as it is the most conservative value and many of these filters are still operating in Hanford tank farms.

In summary, this specification maximum differential pressure limit for breather filters provides the following features to make it acceptable for use on Hanford tanks:

- Low resistance path (i.e. low differential pressure) preferentially channels Hanford tank breathing air to and from the atmosphere through the breather filters instead of other more torturous tank leakage paths that are generally unfiltered,

- Limit is applied consistently over the wide range of In-place Leak test flow rates because it is adjusted to the tested flow rate to determine relative loading on the filter.

- Works in conjunction with the seal loop, the Hanford tank safety pressure relief device for passive ventilation, by operating below the seal loop's minimum pressure limit of 4.0 in. w.g.

Based on this information, it appears that even though the $1.6 \mathrm{in}$. w.g. may be conservative compared to the limit set in the active ventilation system HEPA filters basis, it is acceptable for use in this application since it is checked less frequently than active ventilation systems (once a year compared to daily) and has had little consequence in many years of operation at the Hanford Site.

The breather filter is the primary pressure relief while the associated seal loop is the secondary pressure relief. Setting the breather filter differential pressure significantly below that of the seal loop's lower relief pressure limit of $4.0 \mathrm{in}$. w.g. allows the seal loop to perform its intended function as secondary tank pressure relief. If a seal loop associated with a breather filter is found to be activated (liquid blown out), the effects to the breather filter should be assessed; this assessment may require in-place testing to check the integrity of the breather filter. 
RPP-11413 Rev. 1

\subsubsection{Basis - Minimum Differential Pressure (All Exhaust HEPA Filters on Active Ventilation Systems)}

The minimum pressure specification limit has a minimal technical bases supported by a combination of good engineering judgment and historical operating experience at Hanford. This specification limit is not based on any "industry standard" or calculation but has been arbitrarily chosen to conform with current Hanford values, to minimize system changes, and to provide a consistent value for use by operations. Further refinement of this limit may occur upon more review of Tank Farm operational requirements and it is possible that this measurement for detecting HEPA filter failures is not useful.

\subsubsection{Minimum Operating Limit: 0.1 inches water gage}

The Minimum Operating Limit, 0.1 in. w.g., applies only to exhaust HEPA filters on active ventilation system. This limit is not applicable to active inlet or passive ventilation systems configuration, primarily because these systems have one or more of the following conditions:

- Low flow rates and corresponding low pressure differential - This is especially true of passive ventilation systems and associated breather filter ventilation systems that could frequently have differential pressure limit less that 0.1 in. w.g. Some active ventilation system inlet flow rates through the HEPA filters are very low because the active ventilation system may be drawing air from multiple inlet sources and may have significant in-leakage from other sources than the inlet HEPA filter(s).

- Minimal ALARA concerns - On active ventilation systems, the inlet HEPA filtration is not as critical as the exhaust HEPA filtration because its function is to draw air into the tanks and away from personnel. A failure of an inlet filter on an operational active ventilation system has essentially minimal impact on maintaining ALARA, whereas, an exhaust filter generally may have a major impact on maintaining ALARA.

This specification limit is an engineering control set to detect when a HEPA filter may no longer be functioning properly or a HEPA filter has failed. This specification limit is set lower than the normal operating range of the HEPA filter (typically in the range of 0.2 to 5 in. w.g.) and higher than the minimum resolution level that is detectable by the differential pressure system (less than 0.1 in. w.g.) to reduce false alarms while still performing the intended function of detecting a leaking or failed HEPA filter. A minimum resistance of a new / clean HEPA filter is not given in any of the standards or guidance documents. For new / clean HEPA filters at rated flow (manufacturer's maximum rated flow) the maximum resistance ranges from 1.0 to $1.3 \mathrm{in}$. w.g. (ASME 1997, Article FC-4110 HEPA Filters and associated Table FC-4000-1 Nominal Sizes and Ratings) and the minimum resistance ranges from 0.5 to $0.8 \mathrm{in.} \mathrm{w.g.} \mathrm{(Flanders} \mathrm{Corporation,}$ see Appendix E). The differential pressure decreases linearly with flow rate within the rated range of the HEPA filter. For an active ventilation system, the lower flow rate can be nominally set at 20 percent of rated flow to match the lower range of manufacturer's efficiency testing. Using the extreme limits of operations ( 0.5 in. w.g. and 20 percent flow), the lowest differential pressure a HEPA filter may see in actual operation is 0.1 in. w.g. 
For system operating close to this specification limit, calculations may be required to ensure that the 0.1 in. w.g. limit is adequate for each system. A small leak in a HEPA filter may not develop enough differential pressure to trigger this specification limit. Note that the overall system may still be monitored by other means including continuous air monitoring (CAM) systems, record samplers, and efficiency testing that may negate the need for calculations since redundant monitoring systems are in place. This specification limit could also be used to detect installation problems with the HEPA filter system that may include a missing filter, a filter not properly seating in housing, a damaged filter, etc.

\subsubsection{Basis - Differential Pressure Frequency}

For active ventilation systems, the HEPA filter differential pressure is monitored at least once daily when the active ventilation system is operating. Daily monitoring of active ventilation system is adequate for the Hanford Site use for the following reasons:

- Operationally monitoring is achievable for systems where differential pressure readings are not automated on the manually recorded tank farm daily round sheets,

- Backs up other ventilation monitoring systems like continuous air monitors (CAMs), and

- Many years of successful operation at the Hanford Site monitoring at this frequency.

For passive ventilation systems, less frequent monitoring of filters than for active ventilation systems is adequate because typically these systems have low flow rates, low pressure differential, low flow and, therefore, load up slowly. For these passive systems, the HEPA filter differential pressure is to be tested at minimum whenever an In-place Leak Test is performed (see section on In-Place Leak Test). This would be at least once every 365 days based on the maximum In-place Leak Test frequency. Although the In-Place Leak Test should detect a HEPA filter failure, a differential pressure is a secondary check for the leakage test and may also ensure that In-Place Leak Test setup is properly configured.

\subsubsection{Related Information}

- Any Limiting Condition for Operation (LCO) in Sections 3.1 and 3.2 (HNF-SD-WM-SAR-067 and HNF-SD-WM-TSR-006);

- HNF-IP-1266, Tank Farm Operations Administrative Controls, 3.C.1.c and 3.C.1.h, Section 5.18 HEPA Filter Controls, 3.C. Program;

- RPP-5594, Evaluation of Alternative Control For Prevention and/or Mitigation of HEPA Filter Failure Accidents at Tank Farm Facilities, Section 4.2 (Gustavson 2000b);

- RPP-6804, Setpoint Calculations For Delta-P Interlocks (Nickolaus 2000); and

- Rockwell Hanford Operations internal letter 65260-80-0905 (Ehli 1980) (see Appendix M). 


\section{RPP-11413 Rev. 1}

\subsection{HEPA FILTER - TEMPERATURE LIMITS}

\subsubsection{Summary}

Table 4-3 summarizes the temperature limits for HEPA filter operation. 
RPP-11413 Rev. 1

Table 4-3. Temperature Limit of HEPA Filters

\begin{tabular}{|l|l|}
\hline $\begin{array}{l}\text { HEPA Filter - General } \\
\text { (Based on Continuous Operation) }\end{array}$ & Temperature Limit \\
\hline $\begin{array}{l}\text { HEPA Filter - Specific } \\
\text { (Active } \\
\text { Exhaust Air Heaters) }\end{array}$ & Maximum $200^{\circ} \mathrm{F}$ \\
\hline & $\begin{array}{l}\text { Frequency of Temperature } \\
\text { Limit Measurement }\end{array}$ \\
\hline Active Ventilation Systems - Operating $230^{\circ} \mathrm{F}$ \\
\hline Electric Heaters - Operating & At least once daily \\
\hline
\end{tabular}

Notes:

(a) Hanford Site tanks with stable waste conditions and / or ventilation systems with wood cases ${ }^{(d)}$.

(b) A normal continuous operating range not exceeding $200^{\circ} \mathrm{F}$ is recommended.

(c) Hanford Site tanks with varying waste conditions and/or ventilation systems with steel cases ${ }^{(d)}$ and/or air heaters that could cause the ventilation air to exceed $200^{\circ} \mathrm{F}$ for short periods of time. For these systems, the higher specification limit is warranted.

(d) The latest designation for HEPA filter mounting component is "case" (see ASME 1997, FC-3100 p. 393). An older designation for HEPA filter "case" was "frame" and is used in some of the older documentation, references, and may be quoted in this section if out of one of those documents.

\subsubsection{Background}

The HEPA filters used in the Hanford Site tank farm operations have two primary sources of added heat above ambient conditions as follows:

- All tanks, heating of the air stream as it passes through the tank head space, and

- Ventilation systems with air stream heaters, heating of the air stream as it passes through the heater.

During normal tank farm operations, the air temperature to the HEPA filters is below $200^{\circ} \mathrm{F}$ (see maximum tank waste temperature profile in Appendix I). Also, for Hanford tank farms, the tank temperatures are limited to $195^{\circ} \mathrm{F}$ by HNF-SD-WM-TSR-006. In the abnormal event where the temperature is elevated above $200^{\circ} \mathrm{F}$ for a short period of time, such as a heater failing in the on position, this specification limit protects the HEPA filters from the periodic maximum service temperature limit of $250^{\circ} \mathrm{F}$ (see Appendix G, Section Environmental Conditions, Heat Resistance) with a $20^{\circ} \mathrm{F}$ safety margin. A maximum temperature limit of $225^{\circ} \mathrm{F}$ for air stream heaters (see ASME N509, 5.5.1 Heater Stage (ASME 1989a)) is related to the HEPA filters since they are always installed downstream of the heating unit. 
HEPA filters used in the Hanford Site tank farm operations are constructed of various materials (see listing in Table 4-4) that have various temperature limits. In general, the case material for HEPA filters used in the Hanford Site tank farm operations is steel. Some wood case HEPA filters still exist in very few Hanford tank farm ventilation systems but there is an ongoing effort to eliminate all wood case filters from Hanford tank farms and replace them with steel cased filters.. There are two HEPA filter case materials, wood and steel. Wood cased filters are limited to $200^{\circ} \mathrm{F}$. For steel cased HEPA filters, operation at high temperature is limited primarily by the sealant (see ERDA 1976, Section 3.2.6 Environmental Properties, Hot Air Resistance and Appendix E) and gasket (see Appendix E) used to seal the HEPA filter media against the inside perimeter of the HEPA filter case.

Many of the temperature bases summarized in this document are based on discussion with Hanford Site tank farm Engineering staff; see supporting notes in Appendix L.

\subsubsection{Basis}

These maximum temperature specification limits have a strong technical bases supported by a combination of manufacturer's data, Hanford procurement documents, standards and guidance documents, good engineering judgment and historical operating experience at Hanford. It is strongly suggested that the maximum continuous temperature limit be used whenever possible as a time limit for the "periodic" has not been defined. Discussions with Flanders have indicated the next planned revision of the ASME AG-1 standard (ASME, 1997) is rumored to include definition of "periodic" as a maximum time period of two hours.

Excessive temperatures at the HEPA filter will cause weakening of the filter case, gaskets, and sealants that could ultimately lead to filter failure. Sources of HEPA filter heating include the inlet air stream from the outside environment (seasonal), outlet air stream from the waste tank heated by the tank waste, and a major source of air stream heating is from air stream heaters, where installed, used to decrease the humidity of the air stream. Other minor sources of HEPA filter heating may come from auxiliary sources, such as solar heating for HEPA filter housing exposed to outside environmental conditions.

The most conservative high temperature limit for HEPA filters used in Hanford Site tank farm operations is $200^{\circ} \mathrm{F}$ for continuous operation; summarized in Table 4-3 and based on data from Table 4-4. For short periods of time, a higher temperature limits of up to $250^{\circ} \mathrm{F}$ is acceptable, with the exception of wood cased filters, as summarized in Table 4-3 and based on data from Table 4-4. For the gasket and sealant materials, higher temperatures will not cause an immediate failure but will shorten the service life of those materials. As part of the manufacturer's HEPA filter qualification testing, the filters must withstand a heated air test of $700{ }^{\circ} \mathrm{F}$ at rated flow for not less than 5 minutes and pass a 3 percent penetration test ( 97 percent efficiency) at rated flow as defined in AG-1 (ASME 1997, Article FC-5150 Resistance To Heated Air).

Maximum temperatures suggested in various standards and guide documents include $250{ }^{\circ} \mathrm{F}$ (see ASME 1997, Section FC-1221), $230^{\circ} \mathrm{F}$ (see ERDA 1976, Section 3.2.6 Environmental Properties and associated Table 3.4 and Table 3.5), and $200^{\circ} \mathrm{F}$ (see ASME 1989b, Section 5.1.1). Other references to maximum temperature limits ranging from 230 to $300^{\circ} \mathrm{F}$ (see 


\section{RPP-11413 Rev. 1}

Appendix M) are based on older information. However, older Hanford Site HEPA filters, some up to 30 years old, were manufactured before these standard and guide documents were in place. Therefore, to limit any confusion related to which documentation applies to any specific filter, the technical basis is not dependent on the standard, guide document, or specification in effect at the time of manufacturer, but is solely based on the materials of construction that can be readily identified by serial number and physical inspection if necessary. 
RPP-11413 Rev. 1

Table 4-4. Temperature Limits of Various HEPA Filter Materials - Continuous Operation (Based on materials of construction)

\begin{tabular}{|c|c|c|}
\hline Component & \multicolumn{2}{|l|}{ Temperature Limit } \\
\hline & Continuous & Periodic \\
\hline \multicolumn{3}{|l|}{ Case Materials } \\
\hline Steel & At least $1000^{\circ} \mathrm{F}^{(\mathrm{a})}$ & No specific data \\
\hline Wood & Maximum $200^{\circ} \mathrm{F}^{(\mathrm{a})}$ & No specific data \\
\hline \multicolumn{3}{|l|}{ Sealant } \\
\hline $\begin{array}{l}\text { Fire-retardant solid } \\
\text { urethane }\end{array}$ & Maximum $200^{\circ} \mathrm{F}^{(\mathrm{a})}$ & Maximum $250^{\circ} \mathrm{F}^{(\mathrm{c}, \mathrm{d})}$ \\
\hline RTV silastic silicone & Maximum $450^{\circ} \mathrm{F}^{(\mathrm{a})}$ & No specific data \\
\hline \multicolumn{3}{|l|}{ Gasket } \\
\hline Neoprene & Maximum $200^{\circ} \mathrm{F}^{(\mathrm{a}, \mathrm{b})}$ & Maximum $250^{\circ} \mathrm{F}^{(\mathrm{c})}$ \\
\hline Silicone sponge & Maximum $450^{\circ} \mathrm{F}^{(\mathrm{a})}$ & No specific data \\
\hline Glass packing & Maximum $1000^{\circ} \mathrm{F}^{(\mathrm{a})}$ & No specific data \\
\hline BLU-JEL (C) Seal & Maximum $392^{\circ} \mathrm{F}^{(\mathrm{a})}$ & No specific data \\
\hline
\end{tabular}

Notes:

RTV $=$ Room Temperature Vulcanizing

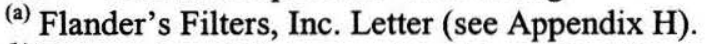

(b) Dupont Dow Elastomers (see Appendix O).

(c) Flander's Filters, Inc. Bulletin No. 936D, page 19, Heat Resistance (see Appendix G).

(d) Flander's Filters, Inc. Bulletin No. 936D, page 5, Sealants (see Appendix G).

\subsubsection{Maximum Temperature Basis (Continuous Operation) $-200^{\circ} \mathrm{F}$}

The maximum temperature basis for continuous operation is $200^{\circ} \mathrm{F}$ based on the following:

- Gasket material: Neoprene (the main gasket material used with Hanford Site tank farm HEPA filters).

- Sealant material: Fire-retardant solid urethane (the primary sealant used with Hanford Site tank farm HEPA filters).

- Case material: Wood (generally excluded for Hanford Site tank farm use but still reside on a few older systems).

The $200^{\circ} \mathrm{F}$ maximum temperature, being the lowest limit of all material for continuous operation, will conservatively cover all Hanford Site tank farm HEPA filter operations. The maximum continuous limit of $200^{\circ} \mathrm{F}$ for urethane sealant and neoprene gasket, are the most common material used in Hanford Site tank farm filters. The bases for all sealant and gasket material values are from Flanders Filters (Appendix $\mathrm{H}$ ) with supplemental information provided by Dupont/Dow for neoprene (see Appendix O). In addition, Hanford Site procurement specifications for many years have a maximum temperature requirement of $200^{\circ} \mathrm{F}$ (see Appendix $\mathrm{C}$ for listing of the current Hanford Site procurement documents and older 
specifications described in Section 4.4.2) The current Hanford Site procurement documents HNF-S-0552, Specification For Procurement of Nuclear Grade High Efficiency Particulate Air (HEPA) Filters (HNF-S-0552) and HNF-S-0447, Specification For Procurement of Nuclear Grade High Efficiency Particulate Air (HEPA) Filter Sizes and Shapes NOT Covered by ASME $A G-1$ (HNF-S-0447) both state in the Section 3.0 Applicability, "This specification applies to extended-media dry type filters for use in air and gas streams with a $200 \mathrm{~F}$ maximum continuous temperature."

Maximum temperature limits for a HEPA filter with wood case is $200^{\circ} \mathrm{F}$ based on the statement in ASME N509 (ASME 1989a, Section 5.1.1, page 17) "Filters exposed to temperatures greater than $200^{\circ} \mathrm{F}$ shall have steel sides." Temperatures in this range are also found in Table 3.5 of the ERDA 76-21 Handbook (ERDA 1976) for wood-cased housing, using plywood, but a lower limit is suggested for humidity conditions higher than 75 percent and indefinite operation. Per discussions with Tank Farm personnel, degradation of wood-cased HEPA filters used in Hanford Site tank farm operation has not been observed and, therefore, a lower maximum temperature limit related to humidity is not required.

A review of all the Hanford Site tanks that are monitored and archived by the Hanford Tank Monitoring And Control System (TMACS) system found that no tank gaseous atmosphere in recent times has exceeded $200^{\circ} \mathrm{F}$ (see Appendix I). These TMACS values are based on the gaseous atmospheric temperature in the tank vapor space, and in general, the exhaust ventilation system being downstream of the tank, should see lower temperatures than these values. All Hanford tank farm active ventilation systems use air stream heaters to adjust the relative humidity of the ventilation system at the entrance of the exhaust ventilation system, but the current maximum limit (see OSD-151-T-00019, Electric Heaters section) is set so that the exhaust ventilation air stream will not exceed $200^{\circ} \mathrm{F}$. For HEPA filters with a heater, past experience with heaters failing to shut off can lead to an over-temperature condition on the HEPA filter (WHC-SD-WM-CN-062). Generally, active tank ventilation system exhausters have an air stream heater high temperature interlock that automatically shuts down the air stream heater upon reaching a high temperature setpoint.

\subsubsection{Maximum Temperature Basis (Periodic Operation) $-230^{\circ} \mathrm{F}$}

The maximum temperature basis for periodic operation is $230^{\circ} \mathrm{F}$ based on the following:

- Gasket material: Neoprene (the main gasket material used with Hanford Site tank farm HEPA filters). This periodic temperature limit for neoprene is less than the continuous operation limit for BLU-GEL (C) Seal (the second most common gasket material used with Hanford Site tank farm HEPA filters).

- Sealant material: Fire-retardant solid urethane (the primary sealant used with Hanford Site tank farm HEPA filters).

- Case material: Steel (Wood should not be used above $200^{\circ} \mathrm{F}$ ).

The $230^{\circ} \mathrm{F}$ maximum temperature, being the lowest limit for periodic operation, will cover Hanford Site tank farm HEPA filter operations that meet these conditions. 
The current HEPA filter standard (ASME AG-1, 1997, "Code On Nuclear Air And Gas Treatment" - Section FC-1221) states "This section applies to extended-media, dry type filters for use in air and gas streams with a $250^{\circ} \mathrm{F}$ maximum continuous temperature." Manufacturer literature from Flanders Filters, Inc. indicates the same $250^{\circ} \mathrm{F}$ limit but based on periodic operation. Based on recent manufacturer data on materials of construction for various filter media (see Appendix $\mathrm{H}$ and Table 4-2), a normal continuous operating range not exceeding $200^{\circ} \mathrm{F}$ is recommended.

Operation of HEPA filters at higher temperatures for short periods of time has been documented in testing (see ERDA 1976, Tables 3.4 and 3.5). In the latest HEPA filter testing standard (ASME 1997, FC-5150), the filter media is qualified to $700^{\circ} \mathrm{F}$ for a minimum of 5 minutes. In general for gasket and sealant materials, operation at slightly higher temperatures than the continuous temperature will not affect the performance of these materials, but may slightly shorten their service life.

This maximum specification limit for periodic operation of $230^{\circ} \mathrm{F}$ protects the maximum temperature limit of $250^{\circ} \mathrm{F}$. The two primary sources that heat the ventilation air stream to the HEPA filter are the waste temperature in the tanks and systems with operating air heaters. Waste in the tanks, currently below $200^{\circ} \mathrm{F}$, will not heat the air stream above $200^{\circ} \mathrm{F}$. Loss of temperature regulation on air heaters can cause the air stream to exceed $200^{\circ} \mathrm{F}$, especially in a failed condition where temperature regulation is lost, but this would only be a periodic condition that is bounded by this specification limit. For ventilation systems that currently have or can lower their maximum HEPA temperature limit to $200^{\circ} \mathrm{F}$, it is recommended that this lower limit be used.

\subsubsection{Temperature Monitoring - Location of Temperature Element}

For Tank Farm systems, the specification temperature limit of the ventilation components (such as HEPA filters, HEGAs, etc.) is monitored using a temperature element that measures the air stream temperature. Ideally, the air stream temperature is monitored before the air stream enters the first HEPA filter, typically on the exhaust stream, to ensure the specification limit is not exceeded. However, some active ventilation systems with heaters may monitor the air stream temperature at other locations including downstream of the first HEPA filter or possibly even upstream of the heater. In these cases, the operating temperature range is adjusted to compensate for the location of the temperature element relative to the HEPA filter. In these cases where temperature adjustments are required, the temperature adjustment value shall be supported by documentation showing how the specification temperature limit at the applicable ventilation component (such as HEPA filters, HEGAs, etc.) is achieved.

\subsubsection{Related Information}

- AC 5.25.2, b., Tank Farms Technical Safety Requirements, Section 5.0 Administrative Controls (ACs), 5.25 Ventilation Controls (HNF-SD-WM-TSR-006); 


\section{RPP-11413 Rev. 1}

- HNF-IP-0842, RPP Administration - 3.5, 3, Volume 6, Environmental, Section 1.7;

- PER 2002-3571, Problem Evaluation Report (Erhart 2002)

- RPP-6331, HEPA Filter Vulnerability Assessment, Section 5.5.3 (Gustavson 2000a); and

- RPP-5594, Evaluation of Alternative Control For Prevention and/or Mitigation of HEPA Filter Failure Accidents at Tank Farm Facilities, Section 5.2.2 (Gustavson 2000b). 


\subsection{HEPA FILTER - IN-PLACE LEAK TEST CRITERIA}

\subsubsection{Summary}

\section{Table 4-5. HEPA Filter In-Place Leak Test}

(a) \% Penetration ${ }^{(\text {(b) }}$ By Challenge Aerosol)

\begin{tabular}{|c|c|}
\hline & Requirement \\
\hline $\begin{array}{l}\text { Single HEPA and/or } \\
\text { Multiple HEPA }\end{array}$ & $\begin{array}{l}\text { Maximum } 0.05 \% \text { Leak/Penetration (equivalent to "Minimum } 99.95 \% \\
\text { Efficiency") using DOE approved challenge aerosol }{ }^{(2)} \text {. } \\
\text { Note: "Maximum } 0.05 \% \text { Leak/Penetration" is equivalent to older nomenclature } \\
\text { which uses "efficiency" or "particle removal efficiency" value of "Minimum } \\
99.95 \% \text { ". The two terms are related by the equation \% Efficiency }=100 \%-\% \\
\text { Penetration. The leak test measures what passes through or around the HEPA } \\
\text { filter verses "efficiency" that measures what is trapped (i.e. not passed through) } \\
\text { by the HEPA filter media. }\end{array}$ \\
\hline Testing Frequency & $\begin{array}{l}\text { The following conditions shall require that the filter system be aerosol tested: } \\
\text { 1. System is new (prior to system startup); } \\
\text { 2. Following any repair, modification, or upgrade to the ventilation system } \\
\text { that could possibly affect the HEPA filter integrity; } \\
\text { 3. Filter(s) replaced; } \\
\text { 4. At least annually; more frequently for special conditions }{ }^{(3)} \text {;or } \\
\text { 5. System is moved (primary applies to portable exhausters). }\end{array}$ \\
\hline $\begin{array}{l}\text { HEPA Filter System } \\
\text { Applicability }\end{array}$ & $\begin{array}{l}\text { This testing applies to all HEPA filters with some exceptions for small, } \\
\text { nontestable units exempted by NOC }{ }^{(4)} \text {. Individual HEPA filters stages are to be } \\
\text { tested with the exception for some systems pre-dating August } 1988 \text { or alternate } \\
\text { method approved by Washington State Department of Health }(\mathrm{WDOH})^{(5)} \text {. }\end{array}$ \\
\hline
\end{tabular}

Notes: Descriptions were changed to match names in the standards ASME AG-1 and ASME N510.

(a) Previously "HEPA Filter Testing and Efficiency"

(b) Previously "Filter Efficiency."

(1) This test is to be performed on each individual filter or, if the configuration of the system does not allow testing of individual filters, on a series of filters. The test should typically be performed at the system design flow rate (i.e. current system operation flow rate); not to be confused with the manufacturer's design flow rate. For HEPA filter systems with low flow rates, such as passive ventilation system breather filters, testing at a flow rate $20 \%$ of the design flow rate or greater is suggested.

(2) Systems are to be in-place tested to ASME N510 Testing of Nuclear Air Treatment Systems, Section 10 HEPA Filter Bank In-Place Testing. For systems that may not quite meet all the in-place testing requirements of ASME N510 (i.e., older systems), the intent of these requirements shall be met (ASME 1989b).

(3) Must occur no later than within the same month of the following year as clarified in AIR 99-718 (Conklin 1999). To cover the worst case scenario of the AIR 99-718 clarification when the test date occurs on the last day of the month, annual may be defined as a maximum of 365 days with no grace period. For HEPA filters exposed to extreme hostile environments (such as high moisture loadings, chemical fumes, or high temperatures, etc.) where the system would not routinely pass an annual test, testing more frequently (semiannually, quarterly, or monthly) may be required.

(4) In-Place Leak Test is not required for those systems installed as small, nontestable units as described in an approved Notice of Construction (NOC) (HNF-IP-0842, Volume 6, Section 1.7, Rev 0b, Section 3.5 Abatement Technology - Emissions Filtration and Treatment -4.). Check for changes or revisions to documentation.

(5) Each filter stage required by the emissions filtration and treatment criteria of this section shall be tested individually, unless the system pre-dates August 1988 and was not built in conformance with ASME/ANSI N509 (ASME 1989a), or unless an alternate method has been approved by WDOH. (HNF-IP-0842, Volume 6, Section 1.7, Rev 0b, Section 3.5 Abatement Technology - Emissions Filtration and Treatment - 5) 
RPP-11413 Rev. 1

\subsubsection{Background}

Although HEPA filters are initially tested by the manufacturer, testing after installation is essential because of damage and deterioration that can occur during handling, shipping, storage, installation, and use. Additionally, in-place testing ensures proper installation and seal of the filter and operation of the ventilation system.

Filter efficiency is a measure of a filter's decontamination factor. Aerosol testing is the accepted means of measuring how many particles pass through filters. Maintaining the specified efficiency enables the ventilation system to meet Federal, State, and DOE regulatory requirements for releases and ensures that the HEPA filter is performing its intended function.

ASME AG-1 (ASME 1997, Article FC-1130 Definitions and Terms) defines a HEPA filter to have the efficiency characteristic as follows: "The filter shall exhibit a minimum efficiency of $99.97 \%$ when tested with an aerosol of essentially monodispersed 0.3 -micrometer diameter test aerosol particles." Current tank farm HEPA filter manufacturers / suppliers meet these efficiency requirements for filter delivery through compliance with ASME AG-1 (ASME 1997) and related ASME/ANSI-N510 (ASME 1989b) and ASME N509 (ASME 1989a). As part of these efficiency inspections / tests, very strict operating parameters are adhered to as defined in ASME AG-1 (ASME 1997), Article FC-5000, Inspection, and specifically, Table FC-5140-3, Test Conditions and Requirements.

In-place testing (also referred to as field testing or surveillance testing), is not the same as the "manufacturer" efficiency testing described above but is a "leakage test" that relates to efficiency. This in-place filter leakage testing at the Hanford Site and other DOE facilities, has historically used an efficiency value of " $99.95 \%$ for a mean particle size of 0.3 micrometer in diameter" or values in the range of that particle size. This lesser efficiency value and particle size for in-place testing is stated directly in ERDA 76-21 (ERDA 1976), Nuclear Air Cleaning Handbook, Section 8.0, "Testing;" specifically Section 8.1, "Introduction," for efficiency of 99.95 percent and Section 8.3.1 for particle size based on dioctyl phthalate (DOP) with "droplets having a light-scattering NMD of 0.7 micrometer and a size range of approximately 0.1 to 3.0 micrometer."

Although this 99.95 percent efficiency and 0.3 -micrometer particle size is not specifically listed in the other major nuclear ventilation documents with HEPA filter specifications and requirements (i.e., ASME AG-1 [ASME 1997], ASME N509 [ASME 1989a], and N510 [ASME 1989b]), it has historically been used as a requirement at the Hanford Site for over 20 years with satisfactory results in meeting the Hanford Site air emission and Authorization Basis requirements. This lower requirement matches earlier, less strict HEPA standard requirements at the Hanford Site that used the 99.95-percent value for HEPA filter efficiency requirements (for example, RHO-CD-125, Standard for the In-Place Efficiency Testing of Gaseous Effluent HEPA Filter Systems required "99.95 percent efficiency" with "the aerosol have an average particle diameter on the order of 0.5 micron or less. The aerosol shall have $95 \%$ of the particles less than 1.0 micron."). This slightly lesser efficiency can also be justified to allow for differences between the "actual" installation conditions (i.e., in-place testing) versus the "ideal" testing laboratory conditions (i.e., manufacturer testing or DOE Filter Test Facility). 
Today, HEPA filter in-place testing shall be performed in accordance (or to the intent for older systems that can not fully comply) with the requirements of ASME AG-1 Code on Nuclear Air and Gas Treatment (ASME 1997), ASME N510 (or latest version) (ASME 1989b), Testing of Nuclear Air Treatment Systems, specifically Section 10 - "HEPA Filter Bank In-Place Test," and U.S. Energy Research and Development Administration ERDA 76-21 (ERDA 1976), Nuclear Air Cleaning Handbook, Section 8.0, "Testing." These documents are listed in order of precedence for any conflicting requirements. The HEPA filters come pre-qualified under the appropriate sections of these same standards. However, it should be noted that older HEPA filters currently in use at the Hanford Site may not have been initially pre-qualified to these latest requirements but were tested under various requirements at the time that may have included: HPS-151-M, Standard Specification for High Efficiency Particulate Air Filters or HPS-157-M, Standard Specification for Fire- and Moisture-Resistant Nuclear Grade HEPA Filters, or RHO-CD-125, Standard for the In-Place Efficiency Testing of Gaseous Effluent HEPA Filter System, or U.S. Atomic Energy Commission Issue No. 324, U.S. Standard For the Testing of HEPA Filter Systems (AEC Issue 324). All of these older documents have similar requirements to the current requirements that range in efficiency from 99.95 percent to 99.97 percent and nominal particle size around the 0.3 -micrometer diameter size. However, for these filters to be in use at the Hanford Site today, they must periodically meet the latest in-place HEPA filter testing requirements for use or continued use.

For In-place Leak testing, the current particle size definition can be found in ASME N509 (ASME 1989a) and ASME N510 (ASME 1989b) under "Terms And Definitions" for "DOP aerosol". It states in these references,

"a challenge aerosol (dictyl phthalate) for testing HEPA filter banks. The DOP aerosol used for in-place testing of installed HEPA filter systems in accordance with this Standard is a poly disperse liquid aerosol having an approximate light-scattering mean droplet size distribution as follows:

$99 \%$ less than 3.0 micrometer

$50 \%$ less than 0.7 micrometer

$10 \%$ less than 0.4 micrometer

The polydispersed DOP aerosol used for in-place leak testing of systems should not be confused with the 0.3 micrometer monodisperse DOP aerosol used for efficiency testing of individual HEPA filters by manufacturers."

Manufacturer testing of tank farm HEPA filters is done at full (100 percent) and 20 percent of rated airflow capacity. Per ERDA 76-21 (ERDA 1976), Section 8.3.1 "In-Place Testing for HEPA Filters,"

"The in-place test can be made at rated system airflow or at reduced flow. Because diffusion is the primary mechanism of small-particle collection, the test at reduced flow is often more sensitive than the full test. The actual rate of airflow for the reduced flow test is a function of the sensitivity of the photometer; some test agencies test at as low as 5 to 10 percent of rated system airflow. Reduced flow testing also has the advantage that less aerosol is required." 
The aerosol used for In-place Leak Testing at the Hanford Site is a DOE approved Emery 3004 (see Appendix $J$ ) that started being used in 1992. Changes in the aerosol used for in-place testing at the Hanford Site over the years were initiated because the original aerosol used up until about 1980, DOP (dioctyl phthalate), was found to be a carcinogen. DOP was replaced by Di 2-ethylhexyl sebacate (DOS) up until about 1992 when it was found to be a suspected carcinogen. Emery 3004, currently the aerosol used, is believed to be less hazardous for worker use (it is not listed as a carcinogen or suspected carcinogen) and better matches the original aerosol requirements of DOP than DOS; however, there are some minor differences with DOP related to particle size. All three aerosols used are an oil-type / based material that are made into an aerosol by one of two types of aerosol generating machines used at the Hanford Site as follows: (1) cold - uses a shear process to generate the aerosol, and (2) hot - uses a vapor process to generate the aerosol.

Many of the In-Place Leak Test bases summarized in this document are based on discussion with Hanford Site tank farm Engineering staff; see supporting notes in Appendix F, Appendix K, and Appendix L.

\subsubsection{Basis - In-Place Leak Test}

The In-place Leak test specification limits have a good technical bases supported by a combination of standards and guidance documents, environmental and regulatory requirements, manufacturer's data, Hanford procurement documents, good engineering judgment and historical operating experience at Hanford.

In-Place Leak Test is required per HNF-IP-0842 (Volume 6, Section 1.7 - Air Quality Radioactive Emissions, 3.5 - Abatement Technology - Emissions Filtration and Treatment, Items 4 and 5), which states " 4 . Filter systems required by the emissions filtration and treatment criteria of this section shall be leak tested in-place at the operating flow rate using a DOEapproved test aerosol. This leak test is not required for those systems installed as small, nontestable units as described in an approved NOC." and " 5 . All filters required under the emissions filtration and treatment requirements of this section shall remove at least 99.95 percent of approved test aerosol particles, with particle size ranges and median diameter as specified by ASME/ANSI N510. Additionally, each filter stage required by the emissions filtration and treatment criteria of this section shall be tested individually, unless the system pre-dates August 1988 and was not built in conformance with ASME/ANSI N509, or unless an alternate method has been approved by WDOH."

The current Tank Farms Final Safety Analysis Report (FSAR) (HNF-SD-WM-SAR-067), Section 4.4.3.3 Functional Requirements, supports testing by stating "HEPA filter units shall: Remove at least $99.95 \%$ of particles of an approved challenge aerosol that are as small as $0.3 \mu \mathrm{m} . "$

In-place Leak Testing requirements are found in the following documents listed in order of preference: 
- AG-1, Section TA, Field Testing of Air Treatment Systems (ASME 1997);

- ASME N510, Section 10, "HEPA Filter Bank In-Place Test" (ASME 1989b); and

- ERDA 76-21, Section 8.3.1, "In-Place Testing for HEPA Filters" and Section 8.3.3, "In-Place Testing for Multistage Systems" (ERDA 1976).

None of the above three HEPA standard or guidance documents mention an In-Place Leak Test requirement of a minimum 99.95 percent efficiency (equivalent to 0.05 percent penetration/leakage). Standard ASME AG-1, Section TTA-4610 (ASME 1997) states "in-place test results shall be conducted and verified to be within acceptable limits of the owners design specification." This 99.95 percent limit appears to be based on historic HEPA filter testing that in some incidences in earlier Hanford specifications (HPS-151-M, 5.1 d) that only required 99.95 percent from the manufacturer's efficiency testing instead of the current minimum 99.97 percent. As noted in the background section, the In-place Leak Test is similar to the manufacturer's Efficiency Test in concept, but the In-place Leak Test is not performed under the same controlled conditions and therefore warrants a slightly lower rating. Finally, the use of 99.95 percent (equivalent to 0.05 percent penetration/leakage) has been proven with over 20 years of experience at the Hanford Site and other DOE sites.

The current Hanford Site use of the term "efficiency" related to In-Place Leak Test is perhaps improper based on the latest ventilation standard AG-1 (ASME 1997). Penetration, not efficiency, is usually specified in test procedures because HEPA filters have efficiencies so near 100 percent, for example 99.97 percent on 0.3 -um particles. The two terms, percent penetration (P) and percent efficiency $(E)$, are related by the equation $E=100 \%$ - P. Because the Hanford Site FSAR (HNF-SD-WM-SAR-067), and some of the older standards/guidance documents, quote this In-Place Leak Test requirement as an "efficiency;" it will continue to be also quoted along with the "\% leak/penetration" in the specification limits to avoid confusion until the FSAR can be updated.

\subsubsection{DOE Approved Challenge Aerosol}

Most all standards, guidance documents, and other references refer to DOP as the In-place Leak Test challenge aerosol. For the Hanford Site, DOP has been changed to Emory 3004 per the U.S. Department of Energy, Richland Operations Office (RL) letter "Use Of Emory 3004 For In-Place HEPA Testing," (see Appendix J), approved this aerosol as an alternative to dioctyl phthalate (DOP). Therefore, in all documents (including procedures) related to In-place Leak testing, all references to DOP should be changed to Emory 3004.

\subsubsection{Basis - In-Place Leak Test Frequency}

The bases for the In-place Leak Test frequencies are covered in ERDA 76-21 (ERDA 1976, Section 8.3, second paragraph, and Section 8.3.5, "Frequency of Testing") for items 1 to 4 in the summary section.

1. System is new (prior to system startup):

Supporting references: 
- ASME N510 (ASME 1989b), Testing of Nuclear Air Treatment Systems, Table 1, Inplace leak test, HEPA filters,

- ERDA 76-21 (ERDA 1976) Sections 8.3, second paragraph, and 8.3.5 Frequency of Testing;

- HNF-IP-0842, Volume: 6, Environmental, Section: 1.7, Rev 0b, Air Quality Radioactive Emissions) "3.5 Abatement Technology - Emissions Filtration and Treatment: 3;

- FSAR (HNF-SD-WM-SAR-067), Section 4.4.3.5 Controls (Technical Safety Requirement); and

- HNF-IP-1266, Section 5.18, 3.C.1.h.

- Regulatory Guide 1.140 , Section 6.2

Clarification / Basis:

For a new system, the completed, installed, and ready for operation HEPA filter assembly needs to be leak tested to "qualify" the system for safe operation. Even though individual components of the system (such as HEPA filters) may have been individually tested, storage of these components prior to installation and startup, assembly and installation, could degrade or damage the components and affect the integrity of the overall ventilation system.

2. Following any system repair, modification, or upgrade to the ventilation that could possibly affect the HEPA filter integrity:

Supporting references:

- ASME N510 (ASME 1989b), Testing of Nuclear Air Treatment Systems, Table 1, Inplace leak test, HEPA filters,

- ERDA 76-21 (ERDA 1976) Sections 8.3, second paragraph, and 8.3.5 Frequency of Testing

Clarification / Basis:

As stated in guidance document reference ERDA 76-21 (EDRA 1976), a condition for in-place testing is "Following any major system repair or modification." Because this statement is vague and can be broadly interpreted, it has been clarified further to include any work on or near the ventilation system, even minor work, but only if it could affect the integrity of the HEPA filter operation. For example, a ventilation repair of a damper or fan being a distance away from the HEPA filter, may be evaluated to not affect the integrity of the HEPA filters; for this case, the requirement does not apply. Another example, if a replacement of a HEPA filter is adjacent or close to a second HEPA filter, both HEPA filters may need to be tested. For all evaluations, personnel knowledgeable with the specific ventilations system (i.e., system engineers, design authorities, etc.) shall make the evaluation. 
RPP-11413 Rev. 1

3. Filter(s) replaced:

Supporting references:

- ASME N510 (ASME 1989b), Testing of Nuclear Air Treatment Systems, Table 1, Inplace leak test, HEPA filters,

- ERDA 76-21 (ERDA 1976) Sections 8.3, second paragraph, and 8.3.5 Frequency of Testing;

- HNF-IP-0842, Volume: 6, Environmental, Section: 1.7, Rev 0b, Air Quality Radioactive Emissions) "3.5 Abatement Technology - Emissions Filtration and Treatment: 3 ; and

- HNF-IP-1266, Section 5.18, 3.C.1.h.

- Regulatory Guide 1.140 , Section 6.2

Clarification / Basis:

When a ventilation system component is replaced, the integrity of the equipment and components could be degraded. Testing of the new HEPA after replacement verifies that the HEPA system leakage is in an acceptable range prior to reuse. Unacceptable leakage of the new HEPA filter can occur from long term storage, handling, or failure of the gasket to adequately seal into ventilation duct work.

4. At least annually:

Supporting references:

- ASME N510 (ASME 1989b), Testing of Nuclear Air Treatment Systems, Table 1, Inplace leak test, HEPA filters [Note: Once per operating cycle, as stated in this reference has been defined as every 365 days for Hanford. The documentation rated to this Hanford definition was not obtained, but discussions with the Hanford tank farms environmental personnel, this was documented in some meeting minutes.]

- ERDA 76-21 (ERDA 1976) Sections 8.3, second paragraph, and 8.3.5 Frequency of Testing;

- HNF-IP-0842, Volume: 6, Environmental, Section: 1.7, Rev 0b, Air Quality Radioactive Emissions) "3.5 Abatement Technology - Emissions Filtration and Treatment: 3. - Note also "Those systems that handle high levels of radioactivity (as judged by the facility cognizant engineer or cognizant project engineer) and/or are exposed to extreme hostile environments (as judged by the cognizant engineer and/or designee), such as high moisture loadings, chemical fumes, or high temperatures, shall be tested semiannually, quarterly, or monthly, as dictated by the operational requirements of the system;"

- AIR 99-718 (Conklin 1999);

- FSAR (HNF-SD-WM-SAR-067), Section 4.4.3.5 Controls (Technical Safety Requirement); and

- HNF-IP-1266, Section 5.18, 3.C.1.h. 
- TFC-ENG-STD-C-07, Section 2.9 Testing and Maintenance

- SD-WM-ES-270 (For breather filters only)

Clarification / Basis:

The term "annual" has been defined for in-place leak testing of HEPA filters by the WDOH as "Must occur no later than within the same month of the following year." This is the "real" requirement for annual in-place leak testing. The worst case of this requirement would be a maximum of 365 days for an in-place leak test that was done the last day of the month of the following year. Restricting the "annual" limit to be "365 days with no grace period" is optional to ensure the WDOH requirements are always fulfilled and to minimize interpretation errors.

For the HEPA breather filters an assessment (WHC-SD-WM-ES-270) changed the testing frequency to annually for a majority of the breather filters based failure history, radiation risk exposure, and costs. Only breather filters on Hanford tanks 241-C-103, 241-BX-101, and 241-TX-113 have a testing frequency more frequently than annually because of their HEPA test failure history.

5. System is moved:

Supporting references:

- HNF-IP-1266, Section 5.18, 3.C.1.h.

Clarification / Basis:

This specification limit applies primarily to portable exhausters. When a ventilation system such as a portable exhauster is moved, the integrity of the equipment and components could be changed or damaged. Testing after moving verifies that the HEPA system leakage is in an acceptable range prior to use at new location. Because portable exhauster systems are not addressed in the various HEPA ventilation system standards, such as ASME AG-1 (ASME 1997), "good engineering practice" has been used, however, this specification limit basis is related to the various HEPA standards covered by (1) "System is new" or (2) "Following any system repair, modification." 


\subsubsection{Related Information}

- See AC 5.18.2, c. and e, TSR (HNF-SD-WM-TSR-006, Section 5.0 Administrative Controls (ACs), 5.18 HEPA Filter Controls).

- See HNF-IP-0842 - 3.5, 3 and 4 and 5 (Volume 6, Environmental, Section 1.7).

- See HNF-IP-1266, 3.C.1.c and 3.C.1.i (Section 5.18 HEPA Filter Controls, 3.C. Program).

- See HNF-IP-1266, Attachment, Exemption from Double-Contained Receiver Tank (DCRT) HEPA Filter Efficiency Test (Section 5.18 HEPA Filter Controls, 3.C. Program). 
RPP-11413 Rev. 1

\subsection{REFERENCES}

AEC Issue 324, 1973, U.S. Standard For the Testing of HEPA Filter Systems, Issue No. 324, U.S. Atomic Energy Commission, Washington, D. C. (RMIS: D196846622)

ASME, 1989a, Nuclear Power Plant Air-Cleaning Units and Components, ASME N509, American National Standard, The American Society of Mechanical Engineers, New York, New York.

ASME, 1989b, Testing of Nuclear Air Treatment Systems, ASME N510, American National Standard, The American Society of Mechanical Engineers, New York, New York.

ASME, 1997, Code on Nuclear Air and Gas Treatment, ASME AG-1, American National Standard, The American Society of Mechanical Engineers, New York, New York.

Conklin, A. W., 1999, "State of Washington, Department of Health, Notice of Correction for the May 19, 1999, EPA Level II Inspection of the 291-Z-1 Emission Unit in the 200 West Area of the Hanford State," (AIR 99-718/9955340 to J. E. Rasmussen, RL, July29), State of Washington Department of Health, Olympia Washington. (RMIS: D199149320)

DNFSB/TECH-23, 1999, HEPA Filters Used in the Department of Energy's Hazardous Facilities, Defense Nuclear Facilities Safety Board, Washington, D.C. (Internet: http://www.dnfsb.gov/pub_docs/dnfsb/tr 19990608.pdf).

DOE/ORP-2000-20, 2000, Assessment of Potential Vulnerability Due To Degraded High-Efficiency Particulate Air (HEPA) Filters in Nuclear Facilities, (RMIS: D8654796), U.S. Department of Energy, Office of River Protection, Richland, Washington.

Ehli, T. J., 1980, “AW Tank Farm Process Specification - HEPA Filters," (internal letter 65260-80-0905 to Tank Farm Process Control File, March 27), Rockwell Hanford Operations, Richland, Washington.

ERDA, 1976, Nuclear Air Cleaning Handbook-Design, Construction, and Testing of High-Efficiency Air Cleaning Systems for Nuclear Application, ERDA 76-21, U.S. Energy Research and Development Administration, Washington, D.C.

Erhart, S. W., 2002, Problem Evaluation Report, PER 2002-3571, CH2M HILL Hanford Group, Inc., Richland, Washington

Gustavson, R. D., 2000a, HEPA Filter Vulnerability Assessment, RPP-6331, Rev. 0, CH2M HILL Hanford Group, Inc., Richland, Washington. 
Gustavson, R. D., 2000b, Evaluation of Alternative Control For Prevention and/or Mitigation of HEPA Filter Failure Accidents at Tank Farm Facilities, RPP-5594, Rev. 0, CH2M HILL Hanford Group, Inc., Richland, Washington.

Gustavson, R. D., 2001, Engineering Standard For Design, Procurement, Construction, and Acceptance Of Tank Farm Radioactive Air Emission Units, 7G000-01-019, CH2M HILL Hanford Group, Inc., Richland, Washington.

Gustavson, R. D., 2002, Technical Justification For Operating Tank 241-C-103 Breather Filter in Excess of Rated Flow, RPP-12401, CH2M HILL Hanford Group, Inc., Richland, Washington.

HNF-IP-0842, RPP Administration, as amended, CH2M HILL Hanford Group, Inc., Richland, Washington. (Hanford Intranet: http://aptfpg02/twrsadmin procedures/category.htm)

HNF-IP-1266, Tank Farm Operations Administrative Controls, as amended, CH2M HILL Hanford Group, Inc., Richland, Washington. (Hanford Intranet: http://aptfpg02/1266 Procedures/1266.htm)

HNF-RD-8703, 2001, Air Quality - Radioactive Emissions, Rev. 0, (replaced HNF-PRO-450), Fluor Hanford, Richland, Washington.

HNF-S-0552; 2002, Specification For Procurement of Nuclear Grade High Efficiency Particulate Air (HEPA) Filters, Rev. 4, Fluor Hanford, Richland, Washington.

HNF-S-0477, 2002, Specification For Procurement of Nuclear Grade High Efficiency Particulate Air (HEPA) Filter Sizes and Shapes NOT Covered by ASME AG-1, Rev. 5, Fluor Hanford, Richland, Washington.

HNF-SD-RE-TI-223, 2001, Technical Basis for the 241-AZ-702 Vessel Ventilation System Operating Specifications, Rev. 1, CH2M HILL Hanford Group, Inc., Richland, Washington.

HNF-SD-WM-SAR-067, Tank Farms Final Safety Analysis Report, as amended, CH2M HILL Hanford Group, Inc., Richland, Washington. (Hanford Intranet: http://apweb05.rl.gov/chg/chgab/index 3.cfm?FileName=\%2Fdocs $\% 2$ F6 $\% 2$ Fdocs $\% 2$ Ftoc main $\% 2$ Ehtm\&Pagenum $=6$ )

HNF-SD-WM-TSR-006, Tank Farms Technical Safety Requirements, as amended, CH2M HILL Hanford Group, Inc., Richland, Washington. (Hanford Intranet: http://apweb05.rl.gov/rapidweb/chg/chgab/docs/30/docs/tsrmain.htm

HPS-151-M, 1976, Standard Specification for High Efficiency Particulate Air Filters, Rev. 2, ERDA, Richland, Washington. (RMIS: D196804008)

HPS-157-M, 1986, Standards Specification for Fire- and Moisture-Resistant Nuclear Grade HEPA Filters, Rev. 1, U.S. Department of Energy, Richland, Washington. 
Lowe, D. C., 2001, “Operating Specification Document Effectivity Assessment Report,” (internal memorandum 7G000-01-005 to D. I. Allen et al., June 27), CH2M HILL Hanford Group, Inc., Richland, Washington.

Nickolaus, C. M., 2000, Setpoint Calculations For Delta-P Interlocks, RPP-6804, Rev. 0, COGEMA Engineering Corporation, Richland, Washington.

OSD-151-T-00007, 2002, Operating Specifications for the 241-AN, AP, AW, AY, AZ \& SY Tank Farms, Rev. H25, CH2M HILL Hanford Group, Inc., Richland, Washington. (Hanford Intranet: $\underline{\text { \APTFPG03\WEBPROC\Technical } \backslash O S D \backslash C \text { Controlled } \backslash O S D-T-151-}$ 00007C.PDF)

OSD-151-T-00008, 2000, Operating Specifications for 204-AR Waste Unloading Facility, Rev. E4, CH2M HILL Hanford Group, Inc., Richland, Washington. (Hanford Intranet: $\underline{\backslash \text { Aptfpg03\webproc } \backslash \text { Technical } \backslash O S D \backslash C \text { Controlled } \backslash O S D-T-151-00008 C . p d f)}$

OSD-151-T-00011, 2002, Operating Specifications for the Saltwell Receiver Vessels, Rev. C8, CH2M HILL Hanford Group, Inc., Richland, Washington. (Hanford Intranet:

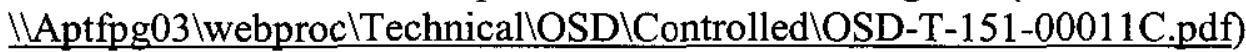

OSD-151-T-00013, 2002, Operating Specifications for Single-Shell Waste Storage Tanks, Rev. D21, CH2M HILL Hanford Group, Inc., Richland, Washington. (Hanford Intranet:

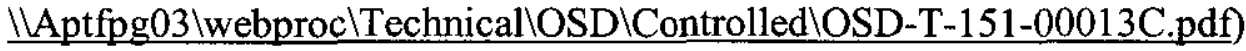

OSD-151-T-00014, 2000, Operating Specifications for the 244-AR Vault Facility Rev. A8, CH2M HILL Hanford Group, Inc., Richland, Washington. (Hanford Intranet:

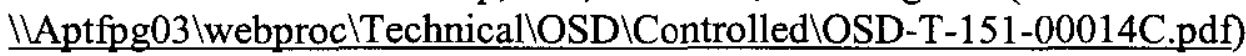

OSD-151-T-00015, 2002, Operating Specifications for Miscellaneous Facilities, Rev. B16, $\mathrm{CH} 2 \mathrm{M}$ HILL Hanford Group, Inc., Richland, Washington. (Hanford Intranet:

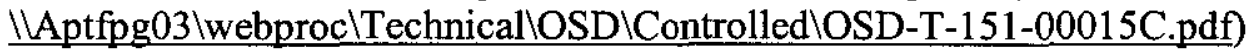

OSD-151-T-00019, 2000, Operating Specifications for the 241-AZ-702 Vessel Ventilation System, Rev. B3, CH2M HILL Hanford Group, Inc., Richland, Washington. (Hanford

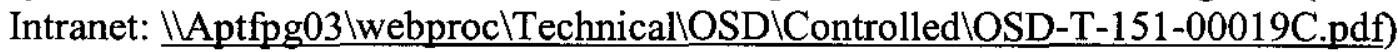

Regulatory Guide 1.140, 2001, Design, Inspection, and Testing Criteria For Air Filtration and Adsorption Units of Normal Atmosphere Cleanup Systems in Light-Water-Cooled Nuclear Power Plants, U.S. Nuclear Regulatory Commission, Washington, DC.

RHO-CD-125, 1977, Standard for the In-Place Efficiency Testing of Gaseous Effluent HEPA Filter Systems, Rockwell Hanford Operations, Richland, Washington.

TFC-ENG-STD-C-07, Rev A, 2002, Management Of HEPA Filter Systems, CH2M HILL Hanford Group, Inc., Richland, Washington. 


\section{RPP-11413 Rev. 1}

WHC-SD-WM-CN-062, 2000, HEPA Filter Failure by Fire or Heater Overtemperature and Subsequent Unfiltered Release, Rev. 2A, CH2M HILL Hanford Group, Inc., Richland, Washington.

WHC-SD-WM-ES-270, 1994, Single Shell Tank Breather Filter Test Frequency, Rev. 0, Westinghouse Hanford Company, Richland, Washington. 


\subsection{GLOSSARY}

Sources : EDRA 76-21, Nuclear Air Cleaning Handbook (EDRA 1976), ASME AG-1 (ASME 1997)

adsorber - A device for removing gases or vapors from air by means of preferential physical condensation and retention of molecules on a solid surface. Absorbers used in nuclear applications are often impregnated with chemicals to increase their activity for organic radioactive iodine compounds.

adsorber cell - A modular replaceable adsorber element.

air density $-0.075 \mathrm{lb} / \mathrm{ft}^{3}\left(1.201 \mathrm{~kg} / \mathrm{m}^{3}\right)$ for standard air. This corresponds to air at a pressure of $29.92 \mathrm{in.} \mathrm{Hg}(760 \mathrm{~mm} \mathrm{Hg})$ at a temperature of $69.8^{\circ} \mathrm{F}\left(21^{\circ} \mathrm{C}\right)$ with a specific volume of $13.33 \mathrm{ft}^{3} / \mathrm{lb}\left(0.832 \mathrm{~m}^{3} / \mathrm{kg}\right)$

aerosol - A dispersion of very small particles and / or droplets in air.

ALARA - As low a reasonably achievable. The design philosophy used to determine the need for, or extent of, air cleaning and off-gas facilities, based on their cost effectiveness in reducing adverse impacts with respect to offsite and onsite dose criteria.

assembly - Two or more devices sharing a common mounting or supporting structure.

case - HEPA filter mounting component. Formerly sometimes called frame.

component - A constituent of any referenced item. For example, an adsorber is a component of an air cleaning unit. An air cleaning unit and ducts are components of the air cleaning system.

contained space (contained volume) - A building, building space, room, cell, glove box, or other enclosed volume in which air supply and exhaust are controlled.

containment (containment vessel or building) - A gastight enclosure around a nuclear reactor or other nuclear facility design to prevent fission products from escaping to the atmosphere.

contaminated exhaust system - An air cleaning system that is designed to remove harmful or potentially harmful particulates, mists, or gases from the air exhausted from contained space.

contamination - Any unwanted material in the air or on surfaces. For the purpose of this report, contamination is usually assumed to be hazardous or radioactive.

continuous operation - Operation indefinitely. (see periodic operation)

decontamination factor - A measure of air cleaning effectiveness; the ratio of the concentration of a contaminant in the untreated air or gas to the concentration in the treated air or gas. 
demister - The preferred generic term for devices use to remove entrained moisture from air. Other names for these devices are deentrainer, moisture separator, or mist eliminator.

design pressure - see pressure, design

device - An item, component, or accessory that is used in connection with, or as an auxiliary to, other items of equipment.

double filtration - An arrangement of two filters in series with the second proving backup protection against leakage or failure of the first. Also a series arrangement intended to increase the total filtration efficiency or decontamination factor.

DOP aerosol - A dispersion of dioctyl phthalate (DOP) droplets in air.

DOP aerosol, monodisperse - Monodisperse DOP is generated by controlled vaporization and condensation of liquid dioctyl phthalate to give a cloud of droplets with diameters of approximately 0.3 micrometers. Used for efficiency testing of HEPA filters by manufacturers.

DOP aerosol, polydisperse - Polydisperse DOP is generated by blowing compressed air through liquid dioctyl phthalate and exhausting through special nozzles under controlled conditions to produce a cloud of droplets with a light-scattering mean diameter of approximately 0.7 micrometer. Used for in-place HEPA testing for leakage / \% penetration.

dose - The amount of ionizing radiation energy absorbed per unit mass of irradiated material at a specific location. In the human body it is measured in rems; in inanimate bodies it is measure in rads.

double containment - An arrangement of double barriers in which the second barrier provides backup protection against leakage through or failure of the first.

duct - An air or gas path enclosure.

enclosed filter - A filter that is completely enclosed on all sides and both faces except for reduced end connections or nipples for direct connection into a duct system. Enclosed filters are installed individually because there is a separate run of duct to each filter unit.

equipment - All heating, ventilation, and air conditioning (HVAC) components including ductwork, housing, plenums, fans, cleaning and refrigeration devices, dampers, and structural supports.

face guard - A screen, usually made from 4-mesh galvanized hardware cloth, permanently affixed to the face of a filter unit to protect it against damage caused by mishandling.

face shield - A screen or protective grille placed over a filter unit after it is installed to protect it from damage that might be caused from operations carried on in the vicinity of the filter. 
filter - A device having a porous or fibrous media for removing suspended particles from air or gas.

filter bank - A parallel arrangement of filters on a common mounting frame enclose within a single housing.

final filter - The last filter unit in a set of filters arrange in series.

frame - Older designation for HEPA filter mounting component now referred to as "case."

gas chromatograph - An analytical instrument used for quantitative analysis of extremely small quantities of organic compounds whose operation is based upon the absorption and partitioning of a gaseous phase within a column of granular material.

gas residence time - The calculated time that a contaminant or test agent theoretically remains in contact with an adsorbent and air or gas velocity through the adsorber bed.

HEPA filter - High-efficiency particulate air filter. A throwaway, extended-media dry type filter with a rigid casing enclosing the full depth of the pleats. The filter shall exhibit a minimum efficiency of 99.97 percent when tested with an aerosol of essentially monodispersed 0.3-micrometer diameter test aerosol particles.

housing - A duct section that contains one or more components, each of which may be used for moving, cleaning, heating, cooling, humidifying, or dehumidifying the air or gas stream.

in-place test - Penetration test of HEPA filter units or charcoal absorbers made after they are installed.

inches of water - A unit of pressure or pressure differential ( 1 in. w.g. $=0.036 \mathrm{psi})$.

maximum - Not to exceed maximum value. Tolerance is $+/-50$ percent of least significant figure specified. For example, $200^{\circ} \mathrm{F}$, the maximum tolerance would be $200.5^{\circ} \mathrm{F}$.

medium - The filtering material in a filter. The plural form is media.

media velocity - The linear velocity of the air or gas into filter media.

minimum - Not to exceed minimum value. Tolerance is $+/-50$ percent of least significant figure specified. For example, 0.1 inches water gage, the minimum tolerance would be 0.05 inches water gage.

mounting frame - The structure to which a filter unit is clamped and sealed.

off-line system - On that is not operating or is normally held in standby. 
on-line system - On that is operating or is normally in operation, as opposed to an off-line system.

open-face filter - A filter with no restrictions over the ends or faces of the unit, as opposed to the enclosed filter with reduced-size end connections.

operating pressure - see pressure, operating

overpressure - Pressure in excess of the design or operating pressure.

particle, particulate - A minute piece of solid matter having measurable dimensions. Also a radioactive particle (alpha, beta) which can liberate ionizing radiation or (neutron) which can initiate a nuclear transformation.

penetration - The measure of the quantity of a test agent that leaks through or around an air cleaning device when the device is tested with an agent of known characteristics under specified conditions; penetration is expressed as a percentage of the concentration of the test agent in the space upstream of the air cleaning device.

penetrometer - A device for generating essentially 0.3 micrometer diameter monodisperse test aerosol and for evaluating the aerosol penetration and air resistance of fabricated HEPA filters.

periodic operation - Operation for a limited amount of time.

plenum - A section of duct in the air flow path that has a sufficient cross-sectional area and depth to cause substantial reduction in flow velocities. The plenum may contain flow adjustment devices and may collect and distribute several air or gas streams.

poison - Any material that tends to decrease the effectiveness of an adsorbent by occupying adsorption sites on the surface of the adsorbent or by reacting with the impregnants in the adsorbent.

prefilter - A filter unit installed ahead of another filter unit to protect the second unit from high dust concentration or other environmental conditions. The prefilter usually has a lower efficiency for the finest particles present in the aerosol than the filter it protects (see roughing filter)

pressure, maximum design (test pressure) - The pressure that is used to test / qualify a unit per AG-1 (ASME 1997) Table FC-5140-3, HEPA Test Pressure.

pressure, operating - The desired pressure corresponding to any single condition of operation.

pressure, structural design - The pressure that is used for the structural design of a unit, component, or system, and which includes allowance for forces encountered under system upset conditions. 
PSU adsorber - An adsorber that is permanently installed in a system and that can be emptied of and refilled with adsorbent without removing it from the system.

rad - Radiation absorbed dose, the basic unit of ionizing radiation. One rad is equal to the absorption of 100 ergs of radiation energy per gram of matter.

radiation - The propagation of energy through matter or space in the form of electromagnetic waves or fast-moving particles (alpha and beta particles, neutrons, etc.). Gamma rays are electromagnetic radiation in which the energy is propagated in "packets" called photons.

radioactivity - The spontaneous decay or disintegration of an unstable atomic nucleus accompanied by the emission of radiation.

redundant unit or system - An additional and independent unit or system which is capable of achieving the objectives of the basic system and is brought on-line in the event of failure of the basic system.

rem - Roentgen equivalent man. The unit of absorbed radiation dose in rads multiplied by the relative biological effectiveness of the radiation.

roughing filter - A prefilter with high efficiency for large particles and fibers but low efficiency for small particles; usually of the panel type.

shock overpressure - The pressure intensity over and above atmospheric or operating pressure produced by a shock wave from an explosion, a suddenly closed damper, or other event.

standby system - One held in reserve.

train - A set of components arranged in series. In a filter system this may be as simple as a damper, HEPA filter, fan, and damper or as complex as a damper, condenser, moisture separator, heater, prefilter, HEPA filter, charcoal adsorber, another charcoal adsorber, HEPA filter, fan, and damper.

treatment - The process or removing all or a part of one or more chemical components, particulate components, or radionuclides from an off-gas stream.

water gage - The measure of pressure expressed as height of column of water in inches or millimeters. 1.0 inch water gage $=1.868 \mathrm{~mm} \mathrm{Hg}=0.0361 \mathrm{psi}=249.061 \mathrm{~Pa}\left(\mathrm{~kg} / \mathrm{m}^{*} \mathrm{sec}^{2}\right)$ 
RPP-11413 Rev. 1

APPENDIX A

GENERAL DESCRIPTION OF TANK FARM VENTILATION SYSTEMS (ACTIVE AND PASSIVE) 
RPP-11413 Rev. 1

This page intentionally left blank. 
RPP-11413 Rev. 1

\section{GENERAL DESCRIPTION OF TANK FARM VENTILATION SYSTEMS (ACTIVE AND PASSIVE)}

\section{A1.0 GENERAL}

The Hanford Site tank farm ventilation systems are used to protect the environment, workers, and public, from radioactive and hazardous emissions from Tank Farm systems and operations. The ventilation systems also provide waste tank cooling, ventilation of flammable gases, separation of incompatible materials, etc. Two types of ventilation systems are used in the Hanford Site tank farms:

- Active Ventilation - Air is mechanically forced through the system, typically by a fan; and

- Passive Ventilation - Air is naturally exchanged through the system by environmental changes between the tank and outside environment

The key ventilation system component related to confinement of airborne radiological particulate emissions is the high efficiency particulate air (HEPA) filter. For special conditions, several other ventilation components can be employed to include pre-filter, high efficiency mist eliminator (HEME), high efficiency gas absorber (HEGA), and post-filter.

Some Hanford Site tank farm operations related to waste transfers and retrievals modify the standard operating conditions (Kriskovich 1998) and need to be addressed individually.

\section{A2.0 ACTIVE VENTILATION}

Active ventilation is generally used on tanks or facilities that have a potential for generating medium- to high-levels of radioactive air emission in the vapor space of the tank or facility. For this condition, there is a potential for release of radioactive air emissions; therefore, an aggressive entrainment system provided by an active ventilation system is used. An active ventilation system is aggressive because it "maintains" a negative pressure on the vapor space to prevent migration of radioactive air emissions outside the tank's or facility's environment and forces these emissions to be captured prior to being released to the atmosphere.

A summary of Hanford Site tank farm active ventilation systems (HNF-SD-WM-SAR-067, Section 4.4.8 Safety Function) is as follows:

"Active ventilation systems are provided for some SSTs, the 244-CR Vault, and for all DSTs and AWF tanks. The exhaust from an active ventilation system is typically passed through HEPA filters and then routed to a stack, where it is monitored for radionuclide particles by a CAM before being released to the atmosphere. When the radiation level measured by the CAM exceeds a preset level, an alarm is activated and the ventilation system is automatically shut down." 


\section{A3.0 PASSIVE VENTILATION}

Passive ventilation is generally used on tanks or facilities that have low levels of radioactive air emissions in the vapor space of the tank or facility. This condition limits the potential release of radioactive air emissions to the environment, and therefore, the less aggressive entrainment system provided by the passive ventilation system is adequate.

A summary of Hanford Site tank farm passive ventilation systems for SSTs (HNF-SD-WM-SAR-067, Section 2.4.1.5.2 Passive Ventilation Systems) is as follows:

"Passive ventilation systems serve all SSTs except specific tanks in the 241-C and 241-SX Tank Farms, which are currently actively ventilated. Passive ventilation means that airflow through the tanks is dictated by differences in atmospheric conditions (e.g., temperature and atmospheric pressure) in and out of the tank."

The typical breather filter system used on all passively ventilated tanks with little or no operations or cooling requirements is shown in Figure 2-12 of HNF-SD-WM-SAR-067. Each breather filter consists of a housing that contains a roughing filter, HEPA filter, an outlet screen, and a small seal loop. Other breather filters mount on a single spool piece attached to the tank riser and do not have seal loops. An isolation valve is normally open to permit airflow between the tank vapor space and outside atmosphere through the filter. Air flowing to and from the tank passes through the filter.

Seal loops installed in the exhaust lines are designed to maintain tank pressures near atmospheric and are provided to relieve slight tank pressurizations when the HEPA filter is plugged or isolated for maintenance. The seal loops are inspected weekly and refilled with oil if required."

A summary of Hanford Site tank farm passive ventilation systems for catch tanks and DCRTs (HNF-SD-WM-SAR-067, Section 2.4.5.1.1 Passive Ventilation Systems) is as follows:

"The ventilation systems for the following catch tanks and DCRTs consist of a breather filter similar to the breather filter assemblies on SSTs [described in (HNF-SD-WM-SAR-067, Section 2.4.1.5.2]: 241-EW-151, 241-S-304. The following catch tanks have no ventilation system or breather filter and are indirectly ventilated through waste transfer lines: 241-AX-152, 241-AZ-151, 241-AZ-154, 241-A-350. “ 


\section{RPP-11413 Rev. 1}

\section{A4.0 REFERENCES}

HNF-SD-WM-SAR-067, Rev 3-1, Tank Farms Final Safety Analysis Report, as amended, CH2M HILL Hanford Group, Inc., Richland, Washington. (Hanford Intranet: http://apweb05.rl.gov/rapidweb/chg/chgab/index3.cfm?filename=/docs/11/docs/toc4.htm $\underline{\text { \&PageNum }=11 \text { ) }}$

Kriskovich, J. R., 1998, "Waste Processing Air Cleaning, in Proceedings of $25^{\text {th }}$ DOE/NRC Nuclear Air Cleaning and Treatment Conference, August 3-6, 1998, Minneapolis Minnesota. (Internet: http://tis.eh.doe.gov/hepa/Nureg_25th/waste1.pdf) 


\section{RPP-11413 Rev. 1}

This page intentionally left blank. 
RPP-11413 Rev. 1

\section{APPENDIX B}

HEPA FILTRATION DETAILS OF TANK FARM VENTILATION SYSTEMS

B-1 
RPP-11413 Rev, 1

This page intentionally left blank. 
RPP-11413 Rev. 1

\section{HEPA FILTRATION DETAILS OF TANK FARM VENTILATION SYSTEMS}

A HEPA filter is defined (ASME 1997, Section FC-1130) as follows:

"HEPA filter: high efficiency particulate air filter. A throwaway, extended-media dry type filter with a rigid casing enclosing the full depth of the pleats. The filter shall exhibit a minimum efficiency of $99.97 \%$ when tested with an aerosol of essentially monodispersed 0.3 micrometer diameter test aerosol particles."

Per HNF-IP-0842 (Volume 6, Environmental, Section 1.7, Rev 0b, Section 3.5 Abatement Technology - Emissions Filtration and Treatment):

"HEPA filtration is required on the exhaust of facilities that contain radioactive materials in a dispersible form or unsealed, radioactive material. HEPA equivalent filters or process controls may be used in lieu of HEPA filtration in certain specialized installations."

HEPA filters used in Hanford Site tank farm ventilation systems and related to OSDs, both passive and active, are nuclear grade, fire-resistant HEPA filters. The majority of the HEPA filters used in the various Hanford Site tank farm ventilation systems are manufactured by Flanders Filters, Incorporated. Most Tank Farm HEPA filters are steel cased (i.e., framed) but some are wood cased. The wood cased filters reside primarily within the SST farms. Some HEPA filters at use in the Hanford Site are over 25 years old (Gustavson 2000, Section 5.5.1) and have been accepted for use because they continue to pass the periodic in-place testing requirements. The specifications limits for HEPA filters in this section cover HEPA filters of any age and are intended to protect the tank farm from HEPA filter failure, detect a failure, and to protect the workers during maintenance operations.

A summary of the HEPA filtration system portion of the tank farm ventilation systems (HNF-SD-WM-SAR-067, Section 4.4.3.2, “System Description") is stated is as follows:

"The HEPA filter unit is a sealed enclosure that houses one or more HEPA filter elements, with suitable connections for monitoring the efficiency of the filter. The HEPA filter unit encloses replaceable filter elements. The enclosure provides the structural pathway for channeling the ventilation system flow stream from the waste tank vapor space to and through the HEPA filter elements. As the ventilation system flow stream passes through the filter elements, most of the particulate matter in the flow stream is deposited on the filter media.

The filter media is fabricated from fibrous materials to remove particles in the air stream. HEPA filter units have a minimum filtration efficiency of $99.95 \%$ for particles as small as $0.3 \mu \mathrm{m}$. This is demonstrated through the annual performance of a challenge aerosol test with the maximum in-place bypass of the installed HEPA filter being no greater than $0.05 \%$. The fibrous material is mounted and sealed to a frame, and the frame provides 
sealing faces for installation of the filter element into a mounting enclosure. The HEPA filter unit is provided with connections for measurement of differential pressure across the filter element(s) at normal system flow rates. A high differential pressure is associated with the filter element(s) approaching end of useful life because of plugging, while a low (or near zero) differential pressure usually indicates failed (or punctured) filter element(s).

Hardware is installed to periodically verify the efficiency of the HEPA filter unit through penetration testing using an approved challenge aerosol. Each unit is provided with both an aerosol injection port upstream of the unit and an aerosol sample port downstream of the unit. Filter testing is accomplished using approved maintenance procedures. The HEPA filter housings are accessible for external radiation monitoring, so that the filter element can be replaced before the contact radiation dose rate of the filter element exceeds an administrative limit." 


\section{RPP-11413 Rev. 1}

\section{B1.0 REFERENCES}

ASME, 1997, Code on Nuclear Air and Gas Treatment, ASME AG-1, American National Standard, The American Society of Mechanical Engineers, New York, New York.

Gustavson, R. D., 2000, HEPA Filter Vulnerability Assessment, RPP-6331, Rev. 0, CH2M HILL Hanford Group, Inc., Richland, Washington.

HNF-IP-0842, RPP Administration, as amended, CH2M HILL Hanford Group, Inc., Richland, Washington. (Hanford Intranet: http://aptfpg02/twrsadmin_procedures/category.htm)

HNF-SD-WM-SAR-067, Rev 3-1, Tank Farms Final Safety Analysis Report, as amended, CH2M HILL Hanford Group, Inc., Richland, Washington. (Hanford Intranet: http://apweb05.rl.gov/chg/chgab/index $3 . \mathrm{cfm}$ ?FileName $=\% 2 \mathrm{Fdocs} \% 2 \mathrm{~F} 6 \% 2 \mathrm{Fdocs} \% 2 \mathrm{Ftoc}$ main \%2Ehtm\&Pagenum=6). 
RPP-11413 Rev. 1

This page intentionally left blank. 
RPP-11413 Rev. 1

APPENDIX C

STANDARDS AND GUIDANCE DOCUMENTS

C-1 
RPP-11413 Rev. 1

This page intentionally left blank. 


\section{STANDARDS AND GUIDANCE DOCUMENTS}

Hanford Site tank farm ventilation design, performance, inspection, delivery, installation, startup, and maintenance are governed by requirements in the following standards and guidance documents. These documents are listed in order of precedence should there be conflicting requirements :

- Standard: ASME AG-1, Code on Nuclear Air and Gas Treatment (ASME 1997);

- Standard: ASME N509 (or latest version), Nuclear Power Plant Air-Cleaning Units and Components (ASME 1989a);

- Standard: ASME N510 (or latest version), Testing of Nuclear Air Treatment Systems (ASME 1989b); and

- Guide Document: ERDA 76-21, Nuclear Air Cleaning Handbook-Design, Construction, and Testing of High-Efficiency Air Cleaning Systems for Nuclear Application (ERDA 1976).

All of the above standards and guide documents are currently in the process of revision. ASME AG-1 (ASME 1997) currently has incorporated most the requirements of ASME N509 (ASME 1989a), and ASME N510 (ASME 1989b). Many of the ventilation systems and components were designed, built, and originally tested up to 30 years ago before some of these standards existed. These systems may not fully comply with current standards.

\section{C1.0 SAFETY, ENVIRONMENTAL, AND ADMINISTRATIVE DOCUMENTS}

The Hanford Site safety, environmental, and administrative control documents have requirements related to tank farm ventilations system as follows:

\section{C1.1 SAFETY}

- $\quad$ CH2M HILL Hanford Group, Inc. Safety Basis (CH2M HILL 2002):

- HNF-SD-WM-SAR-067, Tank Farms Final Safety Analysis Report, Rev. 3-B, March 27, 2002.

- HNF-SD-WM-TSR-006, Tank Farms Technical Safety Requirements. Rev. 2-G. NOTE: Special conditions related to ventilation may be found in the Limiting Conditions of Operation (LCO), Administrative Controls (AC), and Open Unreviewed Safety Questions (USQs)/Justification for Continued Operation (JCO).

\section{C1.2 ENVIRONMENTAL}

- OSD-151-T-00032, Environmental Operating Specifications River Protection Project (Currently being updated to a non-OSD document);

\footnotetext{
${ }^{1}$ WAC 246-247-130 Appendix C - ALARACT compliance demonstration, "ASME/ANSI AG-1, Code on Nuclear Air and Gas Treatment - where there are conflicts in standards with the other listed references, this standard shall take precedence."
} 
- WAC 246-247, Radiation Protection - Air Emissions;

- WAC 173-400, General Regulations For Air Pollution Sources;

- WAC 173-401, Operating Permit Regulation;

- WAC 173-460, Controls for New Sources of Toxic Air Pollutants;

- WAC 173-480, Ambient Air Quality Standards and Emission Limits for Radionuclides;

- 40 CFR 61, Subpart H, "National Emission Standards for Emissions of Radionuclides Other Than Radon From Department of Energy Facilities;”

- 40 CFR 61, Appendix B, Method 114, "Test Methods For Measuring Radionuclide Emissions From Stationary Sources;"

- 40 CFR 52, Appendix E, "Performance Specifications and, Specification Test Procedures For Monitoring Systems For Effluent Stream Gas Volumetric Flow Rate;"

- 40 CFR 60, Appendix A - Test Methods - Method 1, Method 1A, Method 2, Method 2A, Method 4, Method 5;

- DOE/EH-0173T, Environmental Regulatory Guide for Radiological Effluent Monitoring and Environmental Surveillance, January 1991;

- WHC-CM-7-5, Environmental Compliance (No longer applicable, recalled October 15, 1998, superceded by OSD-151-T-00032 and IP-0842, Volume 6 for Tank Farm ventilation systems [CH2M HILL Hanford Group, Inc. and River Protection Project] and by HNF-RD-8703, Air Quality - Radioactive Emissions, for all other Hanford Site operations [Fluor Hanford and Project Hanford Management Contractor]); and

- RHO-MA-139, Environmental Protection Manual (No longer applicable, superceded by WHC-CM-7-5.

\section{C1.3 ADMINISTRATIVE CONTROL}

- HNF-IP-0842, RPP Administration,

- HNF-IP-2166, Tank Farm Operations Administrative Controls, and

- TFC-ENG-STD-C-07, Management of HEPA Filter Systems

Many other applicable documents for various Hanford Site tank farm systems also give more specific basis; however, on detailed review of the basis in these documents, many of these bases either no longer apply or were not applicable to the stated application. The basis material is covered in the governing documentation above; however, some of the older systems and components were at the Hanford Site before the above governing documents were in place. Many of these older systems have been either upgraded or no longer used. However, a few components are still in used on Hanford Site tank farm ventilation systems.

The following documents were referenced in the previous revision of the OSDs as related to ventilation. The technical basis section of this document supersedes many of these supporting documents unless referenced specifically. Some of the documents listed here no longer apply but have been listed for information only and reference to technical basis changes as follows: 
- HNF-SD-RE-TI-223, Technical Basis for the 241-AZ-702 Vessel Ventilation System Operating Specifications;

- HWS-10278, Gaseous Effluent HEPA Filter System, In-Place Efficiency Testing of;

- SD-RE-OCD-004, Compilation Of Basis Letters Referenced In 244-AR Vault Operating Specifications;

- SD-RE-TI-008, Compilation of Basis Letters Referenced in 241-AN, $A P, A W, A Y, A Z$, and SY Process Specifications;

- SD-RE-TI-012, Single-Shell Waste Tank Load Sensitivity Study;

- SD-RE-TI-035, Technical Bases for Single-Shell Tank Operating Specifications (Includes internal letter 65950-85-263-AIX, "Process Conditions for Operation of High Efficiency Particulate Air Filtration on Single-Shell Tanks.");

- WHC-CM-7-5, Environmental Compliance (No longer applicable);

- WHC-SD-RE-TI-216, Technical Basis for the 204-AR Waste Unloading Facility Operating Specifications;

- WHC-SD-WM-TI-352, Technical Basis for OSD-T-151-00015; and

- WHC-SD-WM-TI-481, Technical Basis for OSD-T-151-00011.

In addition to Hanford Site tank farm specific documents, many other associated documents, test reports, or new requirements have been published with useful information related to the Hanford Site tank farm ventilation systems.

\section{C2.0 SPECIFIC DOCUMENTATION RELATED TO HEPA FILTERS}

Within the DOE complex, the various standards and guidance documents applicable to HEPA filtration confinement system vary within the DOE complex and are not consistent. This has been noted by the Defense Nuclear Facilities Safety Board assessments related to HEPA filtration as listed below.

- DNFSB/TECH-23, HEPA Filters Used in the Department of Energy's Hazardous Facilities: Reviews have identified potentially significant weaknesses in the maintenance and operation of DOE confinement systems, particularly in the procurement, testing, application, and use of HEPA filters.

- DNFSB TECH-3, Overview of Ventilation Systems at Selected DOE Plutonium Processing and Handling Facilities: Earlier review of DOE facilities with deficiencies shown in adherence to DOE requirements.

A recent assessment of the vulnerability of HEPA Filters at the Hanford Site tank farms by CH2M HILL Hanford Group, Inc. (CH2M HILL) in May 2000 (Gustavson 2000) reviewed HEPA filter safety-related features affected by aging, wetting of filters, exposure to high temperature, exposure to corrosive or reactive chemicals, and exposure to radiation. The overall 
vulnerability assessment (DOE/ORP-2000-20) was issued by ORP in May 2000 (French 2000). This overall assessment resulted in a corrective action letter (Popielarczyk 2000) with a plan to fix deficiencies in six areas as follows:

1. Testing: 244-S, 244-A, and 244-TX HEPA filters do not meet ASME Standard N510 testing requirements,

2. Reliability: HEPA filters may not be adequate due to exposure to low concentrations of hazardous chemicals (ammonia and volatile organic carbons [VOCs]) and filter age,

3. Recordkeeping: Some record dates regarding installation date of HEPA filters are not readily available,

4. Quality Assurance: There are some inadequacies in the storage and handling of HEPA filters,

5. Replacement Criteria Relative to Age: None have been defined, and

6. Tracking: Need improvements in the cradle-to-grave tracking of HEPA filter serial number.

As part of the above assessment (DOE/ORP-2000-20, Executive Summary), the policy and procedures were noted to need improvement. The assessment stated, "Programs need to be established or revised for periodic replacement of HEPA filters, use of independent filter test facility considerations, evaluation of HEPA systems against latest revisions of applicable Code/Standards, and equivalency evaluation of the adequacy of performance testing."

Currently at the Hanford Site, none of the DOE Standards related to HEPA filters are used because the HEPA filters at the Hanford Site do not meet all of the requirements of these documents; specifically ASME AG-1 (ASME 1997). For ordering HEPA filters, DOE-STD-3020-97, DOE Standard Specification for HEPA Filters Used By DOE Contractors, references ASME AG-1 (ASME 1997), Section FC (HEPA Filters), but the DOE standard does not meet the entire Section FC. As a result, the Hanford Site orders HEPA filters with the following specifications:

- HNF-S-0552, Specification For Procurement of Nuclear Grade High Efficiency Particulate Air (HEPA) Filters; and

- HNF-S-0477, Specification For Procurement of Nuclear Grade High Efficiency Particulate Air (HEPA) Filter Sizes and Shapes NOT Covered by ASME AG-1.

In the near future, it is planned that all new HEPA filters destined for the Hanford Site will be verified and inspected and tested at the DOE Filter Test Facility (FTF) prior to delivery to the Hanford Site (Short 2001). The Hanford Site previously has had an exemption to this DOE requirement (Wood 2001) but once initiated, all new Hanford Site filters will meet all of the requirements of the following DOE standards:

- DOE-STD-3022-98, DOE Standard DOE HEPA Filter Test Program; and 
- DOE-STD-3025-99, DOE Standard Quality Assurance Inspection and Testing of HEPA Filters.

Recent receipt inspection data (Slawski 2001) from Los Alamos National Laboratory (LANL), a DOE facility, show HEPA filters test rejection rates as high as 18.7 percent in 1996 and 15 percent during the first six months of 2000 .

For HEPA filters used at the Hanford Site, the FSAR (HNF-SD-WM-SAR-067, Section 4.4.3.1, Safety Function) summarizes the status as follows:

"The existing ventilation HEPA filter units are adequate for the required safety function. Operability of the HEPA filter units is verified at the time of installation and annually thereafter using a challenge aerosol. When the active ventilation system is operating, the differential pressure across the HEPA filters is monitored daily. HEPA filters are purchased from qualified suppliers to the requirements of Hanford Site procurement specification HNF-S-0552, and are tested to exacting national consensus standards (e.g., ASME AG-1, Code on Nuclear Air and Gas Treatment [ASME 1997]). This procurement program helps to ensure that the filter element will adequately meet sealing, structural, environmental, and filtration efficiency requirements."

A key source for information on HEPA filters that includes most or all of the Nuclear Air Cleaning Conference Proceedings can be found at HEPA Filter Web Site link http://tis.eh.doe.gov/hepa/index.html .

Information related to HEPA filter use and operations at other DOE facilities can be found in the following references:

- UCRL-MA-133867; LLNL ES\&H Manual Vol. II - Part 12, General H\&S Control Safety Equipment and Facilities - 12.5 High-Efficiency Particulate Air (HEPA) Filter System Design for LLNL Applications;

- UCRL-AR-133354, HEPA Filter and In-place Leak Testing Standard;

- Fermilab 5091.1, High Efficiency Particulate Air (HEPA) Filters System Program, Fermi National Accelerator Laboratory (Fermilab); and

- Brookhaven National Laboratory: IH62200, Standard Operating Procedure: Program Procedure, HEPA Filter Surveillance Program and IH62300, Standard Operating Procedure: Program Procedure, In-Place HEPA Filter Testing.

Some new and future development and testing of HEPA filters include:

- Upgraded neoprene (Lowe 2001);

- New filter material with promise for high humidity use (Sekellick and Jha 2000); and

- Demonstration of HEPA filter alternatives (SR00-2027). 


\section{C3.0 REFERENCES}

40 CFR 52, "Approval and Promulgation of Implementation Plans," Title 40, Code of Federal Regulations, Part 52. (Internet: http://apweb02.rl.gov/aop/regs/40cfr52e.htm).

40 CFR 60, "Standards of Performance for New Stationary Sources," Title 40, Code of Federal Regulations, Part 60. (Internet: http://apweb02.rl.gov/aop/regs/method1.htm); http://apweb02.rl.gov/aop/regs/method1a.htm); http://apweb02.rl.gov/aop/regs/method2.htm); http://apweb02.rl.gov/aop/regs/metod-2a.htm); http://apweb02.rl.gov/aop/regs/method4a.htm); http://apweb02.rl.gov/aop/regs/method5a.htm).

40 CFR 61, "National Emission Standards for Hazardous Air Pollutants," Title 40, Code of Federal Regulations, Part 61. (Internet: http://apweb02.rl.gov/aop/regs/subh.htm, http://apweb02.rl.gov/aop/regs/subparth.pdf); http://apweb02.rl.gov/aop/regs/m114.htm, http://apweb02.rl.gov/aop/regs/m114.pdf).

ASME, 1989a, Nuclear Power Plant Air-Cleaning Units and Components, ASME N509, American National Standard, The American Society of Mechanical Engineers, New York, New York.

ASME, 1989b, Testing of Nuclear Air Treatment Systems, ASME N510, American National Standard, The American Society of Mechanical Engineers, New York, New York.

ASME, 1997, Code on Nuclear Air and Gas Treatment, ASME AG-1, American National Standard, The American Society of Mechanical Engineers, New York, New York.

CH2M HILL, 2002, CH2M HILL Authorization (Safety) Basis, CH2M HILL Hanford Group, Inc., Richland, Washington. (Intranet:

http://apweb05.rl.gov/chg/chgab/index $3 . \mathrm{cfm}$ ?FileName= $\% 2$ Fdocs $\% 2 \mathrm{~F} 1 \% 2 \mathrm{Fdocs} \% 2 \mathrm{FDef}$ ault $\% 2$ Ehtm\&Pagenum $=1 \&$ ).

DNFSB/Tech-3, 1995, Overview of Ventilation Systems at Selected DOE Plutonium Processing and Handling Facilities, Defense Nuclear Facilities Safety Board, Washington, D.C. (Internet: http://www.dnfsb.gov/pub docs/dnfsb/tr_19950320.html).

DNFSB/TECH-23, 1999, HEPA Filters Used in the Department of Energy's Hazardous Facilities, Defense Nuclear Facilities Safety Board, Washington, D.C. (Internet: http://www.dnfsb.gov/pub docs/dnfsb/tr 19990608.pdf).

DOE/EH-0173T, Environmental Regulatory Guide for Radiological Effluent Monitoring and Environmental Surveillance, January 1991, U.S. Department of Energy, Washington, D. C. (Internet: http://apweb02.rl.gov/aop/regs/0173t-a.htm, http://apweb02.rl.gov/aop/regs/0173t-PDF.zip). 
DOE/ORP-2000-20, 2000, Assessment of Potential Vulnerability Due To Degraded High-Efficiency Particulate Air (HEPA) Filters in Nuclear Facilities, (RMIS: D8654796), U.S. Department of Energy, Office of River Protection, Richland, Washington.

DOE-STD-3020-97, DOE Standard Specification for HEPA Filters Used By DOE Contractors, U.S. Department of Energy, Washington, D.C. (Internet: http://tis.eh.doe.gov/techstds/standard/std3020/std3020.pdf).

DOE-STD-3022-98, DOE Standard DOE HEPA Filter Test Program, U.S. Department of Energy, Washington, D.C. (Internet: http://tis.eh.doe.gov/techstds/standard/std3022/std3022.pdf).

DOE-STD-3025-99, DOE Standard Quality Assurance Inspection and Testing of HEPA Filters, U.S. Department of Energy, Washington, D.C. (Internet: http://tis.eh.doe.gov/techstds/standard/std3025/std3025.pdff).

ERDA, 1976, Nuclear Air Cleaning Handbook-Design, Construction, and Testing of High-Efficiency Air Cleaning Systems for Nuclear Application, ERDA 76-21, U.S. Energy Research and Development Administration, Washington, D.C.

Fermilab, 5091.1, 1995, High Efficiency Particulate Air (HEPA) Filters System Program, Fermi National Accelerator Laboratory, Batavia, Illinois (Internet: http://wwwesh.fnal.gov/FESHM/5000/5091.1.html).

French, R. T., 2000, "Assess Potential Vulnerability Due to Degraded High-Efficiency Particulate Air (HEPA) Filters in Nuclear Facilities," (letter 00-OSD-058 to T. J. Gluathier, DOE-HQ, May 25), U.S. Department of Energy, Office of River Protection, Richland, Washington.

Gustavson, R. D., 2000, HEPA Filter Vulnerability Assessment, RPP-6331, Rev. 0, CH2M HILL Hanford Group, Inc., Richland, Washington.

HNF-IP-0842, RPP Administration, as amended, CH2M HILL Hanford Group, Inc., Richland, Washington. (Hanford Intranet: http://aptfpg02/twrsadmin_procedures/category.htm).

HNF-IP-1266, Tank Farm Operations Administrative Controls, as amended, CH2M HILL Hanford Group, Inc., Richland, Washington. (Hanford Intranet: http://aptfpg02/1266 Procedures/1266.htm).

HNF-RD-8703, 2001, Air Quality - Radioactive Emissions, Rev. 0, (replaced HNF-PRO-450), Fluor Hanford, Richland, Washington.

HNF-S-0552; 2002, Specification For Procurement of Nuclear Grade High Efficiency Particulate Air (HEPA) Filters, Rev. 4, Fluor Hanford, Richland, Washington. 
HNF-S-0477, 2002, Specification For Procurement of Nuclear Grade High Efficiency Particulate Air (HEPA) Filter Sizes and Shapes NOT Covered by ASME AG-1, Rev. 5, Fluor Hanford, Richland, Washington.

HNF-SD-RE-TI-223, 2001, Technical Basis for the 241-AZ-702 Vessel Ventilation System Operating Specifications, Rev.1, CH2M HILL Hanford Group, Inc., Richland, Washington.

HNF-SD-WM-SAR-067, Tank Farms Final Safety Analysis Report, as amended, CH2M HILL Hanford Group, Inc., Richland, Washington. (Hanford Intranet: http://apweb05.rl.gov/chg/chgab/index $3 . \mathrm{cfm}$ ?FileName $=\% 2 \mathrm{Fdocs} \% 2 \mathrm{~F} 6 \% 2 \mathrm{Fdocs} \% 2 \mathrm{Ftoc}$ main\%2Ehtm\&Pagenum=6).

HNF-SD-WM-TSR-006, Tank Farms Technical Safety Requirements, as amended, CH2M HILL Hanford Group, Inc., Richland, Washington. (Hanford Intranet: http://apweb05.rl.gov/rapidweb/chg/chgab/docs/30/docs/tsrmain.htm.

HWS-10278, 1981, Gaseous Effluent HEPA Filter System, In-Place Efficiency Testing of, Rev. A000, Rockwell Hanford Operations, Richland, Washington.

IH62200, 2001, Standard Operating Procedure: Program Procedure, HEPA Filter Surveillance Program, Rev 1, Brookhaven National Laboratory, Safety and Health Division, Industrial Hygiene Group, Stonybrook, New York.

IH62300, 2001, Standard Operating Procedure: Program Procedure, In-Place HEPA Filter Testing, Rev 5, Brookhaven National Laboratory, Safety and Health Division, Industrial Hygiene Group, Stonybrook, New York.

Lowe, D. C., 2001, "Contract Number DE-AC27-99RL14047; Request for Temporary Deviation to American Society of Mechanical Engineers AG-1, Article FC-5100, High-Efficiency Particulate Air Filter Qualification Test Requirements," (letter CHG-0104167 to D. C. Bryson, ORP, August 14), CH2M HILL Hanford Group, Inc., Richland, Washington.

OSD-151-T-00032, 2002, Environmental Operating Specifications River Protection Project, Rev. B0, CH2M HILL Hanford Group, Inc., Richland, Washington.

Popielarczyk, R. S., 2000, “Contract Number DE-AC06-99RL14-47; Corrective Action Plan for Identified Vulnerabilities in the High Efficiency Particulate Air Filter Vulnerability Assessment," (letter CHG-0003349R1 to D. C. Bryson, ORP, July 27), CH2M HILL Hanford Group, Inc., Richland, Washington.

RHO-MA-139, 1985, Environmental Protection Manual, Rockwell Hanford Operations, Richland, Washington. (No longer applicable, superceded by WHC-CM-7-5.) 
SD-RE-OCD-004, 1982, Compilation of Basis Letters Referenced In 244-AR Vault Operating Specifications, Rev. 0, Rockwell Hanford Operations, Richland, Washington.

SD-RE-TI-008, 1988, Compilation of Basis Letters Referenced in 241-AN, AP, AW, AY, AZ, and $S Y$ Process Specifications, Rev. 5, Westinghouse Hanford Company, Richland, Washington.

SD-RE-TI-012, 1982, Single-Shell Waste Tank Load Sensitivity Study, Rev. A-0, Rockwell Hanford Operations, Richland, Washington.

SD-RE-TI-035, 1985, Technical Bases for Single-Shell Tank Operating Specifications, Rev. 1, Rockwell Hanford Operations, Richland, Washington.

Short, J. J., 2001, Contract No. DE-AC27-99RL14047 -Direction to Ensure 100 Percent Quality Assurance (QA) Testing of High-Efficiency Particulate Air (HEPA) Filters at the U.S. Department of Energy (DOE) Filter Test Facility (FTF)," (letter 01-TOD-T104/0103976 to M. P. DeLozier, CH2M HILL, August 20), U.S. Department of Energy, Office of River Protection, Richland, Washington. (RMIS: D8800590)

Sekellick, R., and S. Jha, 2000, A Washable Porous Metal HEPA Filter, Mott Corporation, Farmington, Connecticut. (Internet: (http://www.netl.doe.gov/publications/proceedings/00/ind part00/em2-3.pdf).

Slawski, J., 2001, Quality Assurance Testing of HEPA Filters, Presentation at 2001 QSM/PA Fall Workshop, November 26-28, 2001, Quality Assurance Working Group, November 28, 2001, DOE/NNSA/DP, Washington, D.C. (Internet: www.orau.gov/qsm/Fall01/Presentations/Slawski\%200A\%20HEPA\%20Filters.ppt).

SR00-2027, 2001, Demonstrate Alternative Filtration Technologies To Replace Conventional HEPA Filters, Westinghouse Savannah River Company and U.S. Department of Energy, Savannah River Operations Office, Aiken, South Carolina. (Internet: http://www.srs.gov/general/scitech/stcg/Needs/00-2027.htm).

TFC-ENG-STD-C-07, Rev A, 2002, Management of HEPA Filter Systems, CH2M HILL Hanford Group, Inc., Richland, Washington.

UCRL-AR-133354, HEPA Filter and In-place Leak Testing Standard, Lawrence Livermore National Laboratory (LLNL) Livermore, California

UCRL-MA-133867; LLNL ES\&H Manual Vol. II - Part 12, General H\&S Control - Safety Equipment and Facilities - 12.5 High-Efficiency Particulate Air (HEPA) Filter System Design for LLNL Applications, Lawrence Livermore National Laboratory (LLNL) Livermore, California (Internet: http://www.llnl.gov/es and h/hsm/doc 12.05/doc12-05.html ). 
WAC 173-400, "General Regulations For Air Pollution Sources," Washington Administrative Code, Olympia, Washington. (Internet: http://apweb02.rl.gov/aop/regs/173-400a.htm, http://apweb02.rl.gov/aop/regs/173-400.pdf).

WAC 173-401, "Operating Permit Regulation," Washington Administrative Code, Olympia, Washington. (Internet: http://apweb02.rl.gov/aop/regs/173-401 a.htm, http://apweb02.rl.gov/aop/regs/173-401.pdf).

WAC 173-460, "Controls for New Sources of Toxic Air Pollutants," Washington Administrative Code, Olympia, Washington. (Internet: http://apweb02.rl.gov/aop/regs/173-460a.htm, http://apweb02.rl.gov/aop/regs/173-460.pdf).

WAC 173-480, "Ambient Air Quality Standards and Emission Limits for Radionuclides," Washington Administrative Code, Olympia, Washington. (Internet: http://apweb02.rl.gov/aop/regs/173-480.htm, http:/apweb02.rl.gov/aop/regs/173480.pdf).

WAC 246-247, "Radiation Protection - Air Emissions," Washington Administrative Code, Olympia, Washington. (Internet:

http://www.leg.wa.gov/wac/index.cfm?fuseaction=chapterdigest\&chapter=246-247, http://apweb02.rl.gov/aop/regs/246-247.pdf).

WHC-CM-7-5, 1996, Environmental Compliance, Westinghouse Hanford Company, Richland, Washington. (No longer applicable, recalled October 15, 1998, superceded by OSD-151-T-00032.)

WHC-SD-RE-TI-216, 1991, Technical Basis for the 204-AR Waste Unloading Facility Operating Specifications, Rev. 0, Westinghouse Hanford Company, Richland, Washington.

WHC-SD-WM-TI-352, 1988, Technical Basis for OSD-T-151-00015, Rev. 0, Westinghouse Hanford Company, Richland, Washington.

WHC-SD-WM-TI-481, 1991, Technical Basis for OSD-T-151-00011, Rev. 0, Westinghouse Hanford Company, Richland, Washington.

Wood, R. F., 2001, “Contract No. DE-AC27-99RL14047; Direction to Ensure 100 Percent Quality Assurance Testing of High-Efficiency Particulate Air Filters at the U.S. Department of Energy Filter Test Facility," (letter CHG-0103976 R3 to J. S. O'Connor, ORP, December 20), CH2M HILL Hanford Group, Inc., Richland, Washington. 
RPP-11413 Rev. 1

APPENDIX D

HEPA FILTER DIFFERENTIAL PRESSURE RELATIONSHIPS 
RPP-11413 Rev. 1

This page intentionally left blank.

D-2 


\section{HEPA FILTER DIFFERENTIAL PRESSURE RELATIONSHIPS}

\section{D1.0 OPERATING PRESSURE (CLEAN FILTER)}

By design specification, the maximum resistance (i.e., differential pressure) for a clean filter is not to exceed 1.0 in. w.g. or 1.3 in. w.g., depending on filter size for various filter sizes and designations (ASME AG-1, FC-4220, "Resistance to Airflow" and Table FC-4000-1, "Nominal Sizes and Ratings" [ASME 1997]). These maximum resistance values are listed in Table FC-4000-1 (ASME 1997) for various filter sizes and applicable minimum rated air flow. Since the pressure drop is dependent on flow rate, at the system rated flow, these values may be lower if the system flow rate is lower than the manufacturer's rated flow.

The minimum resistance (i.e., differential pressure) for a clean filter is not listed in any standards because this is not a value any standard would want to limit. The ideal case for minimum resistance would be for the filter to have no resistance; however, this is not the case. In discussions with Flanders Filters, Inc., (see Appendix E), supplier of the majority of the Hanford Site tank farm HEPA filters, a good range for minimum differential pressure value would be 0.5 to $0.8 \mathrm{in}$. w.g. at the manufacturer's rated flow. This range is based on years of Flanders HEPA filters testing at the manufacturer's rated flow to assure compliance with the maximum resistance requirements in ERDA (1976), and previous standards. When filters are tested at manufacturer's flow rate, the actual resistance (i.e., differential pressure) is recorded on the filter. Flanders Filters Inc. does not recall any filters having a resistance less than 0.5 in. w.g. but has typically seen the filters with a resistance as low as $0.8 \mathrm{in}$. w.g. This information also correlates with that found in RPP-5594, Evaluation of Alternative Control For Prevention and/or Mitigation of HEPA Filter Failure Accidents at Tank Farm Facilities, Section 5.1.1 (Gustavson 2000), which states "The initial pressure drop across a clean HEPA filter is approximately 0.8 to $1.0 \mathrm{in.}$ w.g. at rated flow."

\section{D2.0 LEAK TEST PRESSURE (RESISTANCE TO PRESSURE) - BASIS}

Per the FSAR (HNF-SD-WM-SAR-067, Section 4.4.3.4, "System Evaluation"), "HEPA filter units shall: ... Resist leakage when exposed to a differential flow stream pressure of $2.49 \mathrm{kPa}$ (10 in. w.g.)." By design specification (ASME AG-1, FC-5000 Inspection, FC-5100 Qualification Testing, FC-5140 Resistance to Pressure [ASME 1997]), all new filters are qualified (i.e., to leak test pressure) by the manufacturer at $10 \mathrm{in}$. w.g. for one hour under the following conditions defined in Table FC-5140-3 (ASME 1997). For some specific model numbers, a manufacturer may have the HEPA filter "independently" qualified to $10 \mathrm{in}$. w.g. However, qualification is only good for the exact model tested and even a small variation from the specific model number tested would not be qualified. Currently, the Army Aberdeen Proving Ground in Maryland is the only facility qualified to do "independent" qualification testing for DOE HEPA filters. 


\section{D3.0 MAXIMUM DESIGN PRESSURE - BASIS}

Historically the standards, guide documents, and other related documents have established or suggested that the HEPA filter maximum pressure be 10 in. w.g. for continuous operation. This is the same differential pressure limit at which the required leak test pressure (i.e., resistance to pressure test) is performed; although this test is limited to one-hour duration verses continuous. Quotes from several other important references substantiate the maximum pressure of 10 in. w.g.:

- "By specification, new HEPA filters must have sufficient structural strength to withstand a continuously applied overpressure of $10 \mathrm{in}$. w.g. or higher, for at least 15 minutes without visible damage or loss of efficiency. For used filters, a value of 8 in. w.g. is recommended for design or planning purposes." (ERDA 76-21, pages 46-47, Section 3.2, "HEPA Filters," Section 3.2.4, "Mechanical Properties" [ERDA 1976]);

- "The HEPA filters are designed to operate continuously at a pressure drop of 10 in w.g." (Ehli 1980); and

- "The maximum differential pressure allowable on the HEPA filter is $2,491 \mathrm{~Pa}$ (10 in. w.g.)." (FSAR, HNF-SD-WM-SAR-067, Section 3.3.2.4.4).

\section{D4.0 STRUCTURAL DESIGN PRESSURE - BASIS}

The structural design pressure of HEPA filters depends on a variety of operating parameters and mounting conditions. In any case, it must exceed the leak test pressure (resistance to pressure test) of $10 \mathrm{in.} \mathrm{w.g.} \mathrm{For} \mathrm{short} \mathrm{periods} \mathrm{of} \mathrm{time,} \mathrm{the} \mathrm{HEPA} \mathrm{filters} \mathrm{can} \mathrm{withstand} \mathrm{shock} \mathrm{pressures}$ higher than the maximum design pressure.

As stated in ERDA 76-21 (ERDA 1976, Section 3.2.4 "Mechanical Properties"), "Resistance to shock pressures is important in a HEPA filter because it is often the final barrier between the contaminated space and the atmosphere. The shock overpressure resistance of open-face rectangular filters, based on tests by the U.S. Navy, is given in Table 3.3 and Figure 3.4" (ERDA 1976). The recommended shock overpressure design limit for used filters based on a $50 \mathrm{msec}$ duration is shown in Tables 3.3 of the ERDA 76-21 Handbook (ERDA 1976), range from a minimum of $1.2 \mathrm{psi}$ ( 33 in. w.g.) to $2.7 \mathrm{psi}$ ( 75 in. w.g.) for various filter sizes and face guard configurations. "In addition, the filter should be able to withstand the considerably higher, but short duration, overpressures that might be encountered in a tornado or when a damper inadvertently slams shut in the duct system. Although the design basis tornado specifies an overpressure of $3 \mathrm{psi}$ for a period of 3 seconds, it is unlikely that the HEPA filters would be subject to such a condition because of the attenuating effects of the stack, ductwork, and fans."

Additional information related to older HEPA filters (Ehli 1980) states "The HEPA filters are designed to ... withstand pressure surges of 28 in w.g.... while maintaining the specified efficiency ...." 
Discussions with Flanders Filters Inc. (see Appendix E) did not define a maximum structural pressure limit because it was so dependent on the filter, system operating parameters, and mounting. For liability reasons, Flanders Filters, Inc. would not state any structural value greater than the leak test pressure of 10 in. w.g. Discussions with Terry Kaiser (see Appendix K), one of the Hanford Site Systems Engineers on tank farm ventilation systems, suggest that there may have been a failure of a Flanders' HEPA filter as low as 11.0 in. w.g., but the details of this failure are not known.

\section{D5.0 REFERENCES}

ASME, 1997, Code on Nuclear Air and Gas Treatment, ASME AG-1, American National Standard, The American Society of Mechanical Engineers, New York, New York.

Ehli, T. J., 1980, “AW Tank Farm Process Specification - HEPA Filters,” (internal letter 65260-80-0905 to Tank Farm Process Control File, March 27), Rockwell Hanford Operations, Richland, Washington.

ERDA, 1976, Nuclear Air Cleaning Handbook-Design, Construction, and Testing of High-Efficiency Air Cleaning Systems for Nuclear Application, ERDA 76-21, U.S. Energy Research and Development Administration, Washington, D.C.

Gustavson, R. D., 2000, Evaluation of Alternative Control For Prevention and/or Mitigation of HEPA Filter Failure Accidents at Tank Farm Facilities, RPP-5594, Rev. 0, CH2M HILL Hanford Group, Inc., Richland, Washington.

HNF-SD-WM-SAR-067, Tank Farms Final Safety Analysis Report, as amended, CH2M HILL Hanford Group, Inc., Richland, Washington. (Hanford Intranet: http://apweb05.rl.gov/chg/chgab/index 3.cfm?FileName $=\% 2 \mathrm{Fdocs} \% 2 \mathrm{~F} 6 \% 2 \mathrm{Fdocs} \% 2 \mathrm{Ftoc}$ main $\% 2$ Ehtm\&Pagenum $=6$ ) 
RPP-11413 Rev. 1

This page intentionally left blank.

D-6 
RPP-11413 Rev. 1

APPENDIX E

DISCUSSION NOTES RELATED TO HEPA FILTERS

WITH FLANDERS FILTERS, INC., JUNE - AUGUST 2002 
RPP-11413 Rev. 1

This page intentionally left blank. 
RPP-11413 Rev. 1

\title{
DISCUSSION NOTES RELATED TO HEPA FILTERS \\ WITH FLANDERS FILTERS, INC., JUNE - AUGUST 2002
}

\begin{abstract}
Following are applicable excerpts from Mr. Eric Berglin's conversations with Flanders Filters, Inc. from June $4 \& 10,2002$ and August 19, 2002. Items that have been added for clarification to the reader but are not part of the exact original message are shown in italics.
\end{abstract}

\section{Memorandum Documenting Telephone Conversation Regarding Flanders HEPA Filter Design and Operation Parameters with Glen Moore of Flanders Filters Inc. on 6/4/02 from 9:10 to 930 am PST with updated information per phone discussion with Chris Winstead on $6 / 10 / 02$ around 11 am PST)}

The following information was obtained from telephone conversation with Glen Moore (phone 252-923-2911) on 6/4/02 around 9:10 to 9:30 am PST. This conversation was initiated by the e-mail message Eric Berglin sent on 6/3/02 requesting information related to Flanders HEPA filter parameters relevant to continuous operation. Mr. Berglin has summarized the Flanders's response to the parameters below as "Flanders Response." To ensure information is correct, this memorandum was checked and approved by both Glen Moore and Chris Winstead at Flanders Filters Inc.. As Flanders provides almost all the Tank Farm HEPA filters, the information provided by Flanders related to their HEPA filters is directly relevant to supporting the technical basis.

\section{HEPA Filter Parameter - Continuous Operation - Flanders Responses - 6/4/02}

Technical details and supporting basis related to HEPA filters under CONTINUOUS OPERATING from discussions with Flanders:

1) Differential Pressure (Continuous Operations)

a. Maximum Design Pressure @ rated flow - Dirty Filter

Flanders Response: By design specification, all filters are rated for a design pressure of 10 inches water gage. Specific filter model numbers are "independently" qualified at the Army Aberdeen Proving Grounds in Maryland at a cost of approximately $\$ 40,000$ per filter part number that included testing up to the design differential pressure of 10 inches of water. This "independent" qualification is expensive to Flanders, 18 filters have to be provided for each testing sequence, and as a result only a few models out of the close to 100 models available based on part number combinations are tested. Flanders currently has 4 filter model numbers qualified and expect to have a total of 6 qualified by December 2002. For model numbers not specifically "independently" qualified, the 10 inches water gauge design pressure still applies Flanders Nuclear Grade Filters as 
these filters have the same methods and materials of construction and therefore should perform the same as those "independently" qualified. The actual "Structural Capability Pressure" is obviously higher than the "Maximum Design Pressure" but no specific value was given by Flanders.

b. Maximum operating pressure @ rated flow - Dirty Filter

Flanders Response: There is no maximum operating pressure suggested by Flanders because this parameter varies depending on the specific ventilation system parameters and environment. This pressure would fall somewhere between the "maximum design pressure" of 10 inches water gage stated above, and the "suggested replacement pressure" below.

c. Suggested replacement pressure@ rated flow - Dirty Filter

Flanders Response: The industry rule of thumb is to replace the filter when the pressure drop doubles from that of the "clean" filters (i.e., new installed). However, it should be recognized that (1) $80 \%$ of the industry applies to "clean rooms" that operate in a very clean environment and therefore do not "load up" quickly, and (2) filter manufacturers are in the business to sell filters and more frequent change out of filters sell more filters. Historically, filters operating in "dirtier" environments have successfully used 3 to 5 inches water gage for replacement pressure.

d. Maximum operating pressure@ rated flow-Clean Filter

Flanders Response: 1.0 to 1.3 inches water gage at rated flow depending on specific filter.

e. Minimum operating pressure@ rated flow-Clean Filter

Flanders Response: 0.5 inches water gage at rated flow should be a good value to conservatively cover all filters. Each filter specifically list the pressure drop at rated flow and values as low at 0.7 to 0.8 inches water gage have been observed.

\section{2) Temperature (Continuous Operations)}

a. Maximum for sealant - Fire-retardant solid urethane

Flanders Response: $200^{\circ} \mathrm{F}$ for continuous operation.

b. Maximum for sealant - RTV silastic silicone

Flanders Response: $450^{\circ} \mathrm{F}$ for continuous operation.

c. Maximum for gasket - Neoprene

Flanders Response: $200^{\circ} \mathrm{F}$ for continuous operation. This maximum operating temperature has just recently been lowered by Flanders from $230^{\circ} \mathrm{F}$ to $200^{\circ} \mathrm{F}$ based on recent data from the Flanders' neoprene manufacturer.

d. Maximum for gasket - Silicone sponge

Flanders Response: $450^{\circ} \mathrm{F}$ for continuous operation. 
e. Maximum for gasket - Glass packing

Flanders Response: $1000^{\circ} \mathrm{F}$ for continuous operation.

f. Maximum for gasket - BLU-JEL (c) Seal

Flanders Response: $392^{\circ} \mathrm{F}$ for continuous operation.

Flanders Special Note: For short periods of time, the temperature limits may be higher than those listed above.

3) Efficiency

a. Minimum efficiency $\%$

Flanders Response: By definition, HEPA filter efficiency is $99.97 \%$. DOE has used a filter efficiency of $99.95 \%$ in the field but the basis for this requirement is not known.

b. Particle size of efficiency \%

Flanders Response: The nominal particle size is 0.3 micron (or micrometer). This is based on the aerosol DOP.

c. Testing aerosol used for efficiency $\%$

Flanders Response: The testing aerosol used by Flanders for manufacturer's testing is DOP; or PAO (Emory 3004) if specified by the customer.

d. Testing parameter conditions for aerosol testing $\%$

Flanders Response: For manufacturer's efficiency testing, Flanders uses DOP aerosol generated thermally. Test parameters are to AG-1 specifications.

4) Humidity

a. Maximum humidity for wood-cased filter housing

Flanders Response: Wood-cased filter case can accommodate up to $100 \%$ relative humidity. Literature has suggested lower values of relative humidity based on ASME standards for plywood but through years of operational experience, Flanders has not observed problems (i.e., such as wood swelling and filters getting stuck, splitting, etc.) with operations at higher humidity levels. Flanders recommends a steel case filter for applications of high humidity and elevated temperatures.

b. Maximum humidity for steel-cased filter housing

Flanders Response: Steel-cased filters can accommodate up to $100 \%$ relative humidity.

c. Maximum humidity for filter media

Flanders Response: With the Flanders waterproof coating that penetrates through filter material; relative humidities up to $95 \%$ continuous can be 
accommodated. Per specification, a relative humidity of up to $100 \%$ can be accommodated but water on the filter will quickly raise the differential pressure across the filter. Flanders has successful accommodated water on their filter media and when allowed to dry, is not degraded in operating performance. Performance in high humidity by Flanders HEPA filters is better than some other HEPA filter manufactures because Flanders applies waterproofing "through" the filter media, whereas some other manufacturers only apply the waterproofing "on the surface" of the filter media.

d. Any special precautions related to humidity for HEPA filters

Flanders Response: It is good engineering practice to keep the HEPA filters dry. Operation in a high relative humidity environment can, under certain conditions, cause water to condensate on the filter media. Water on the filter media causes the differential pressure to increase and under some conditions could cause filter plugging. Long-term exposure of filter media to water can weaken the filter and lead to filter failure.

5) Environment Constraints

a. Special precautions from acids

Flanders Response: Some acids, like hydro-fluoric and nitric, can attack the glass fibers in the filter media. Flanders can provide additives to the filter media that can accommodate some small fraction of these materials (up 5\%).

b. Special precautions from caustics

Flanders Response: Caustic can attack metal parts in the frame, containment housing, and ductwork. Typically, the greater threat of attack is to other metal parts of the ventilation system and not the metal in the HEPA filter itself.

c. Special precautions from materials that may attack and degrade filter media

i. Wood-cased housing

ii. Steel-cased housing

iii. Aluminum parts

iv. Filter media

Flanders Response: Items here are covered by a. and b. of this same section.

6) Maintenance

a. Manufacturer's suggested shelf life of HEPA filters and any special considerations 
Flanders Response: Flanders has a suggested 3 years of shelf life. The three years is based on limitations from the manufacturers' of the gasket materials, neoprene and silicone. This 3-year shelf life does not apply to the gel seal as these units have seen over 20 years of service. Historically, HEPA filters with gasket materials of neoprene and silicone have greatly exceeded the three-year life and some have seen over 20 years of service.

b. Manufacturer's suggested replacement frequency of HEPA filters and any special considerations

Flanders Response: Flanders has suggested that filters be changed based on the differential pressure. However, DOE has been using in recent years a combination of differential pressure and service life (something on the order of 10 years. This DOE combination is being used at DOE's Savannah River Site.

7) Other related questions (may be related to older filters not in the current Flanders catalog) a. What would a Filter Media of "713" be?

Flanders Response: This is a valid filter media. It is an older "experimental" $99.97 \%$ efficient HEPA filter. This filter had 5\% additional special glass and Nomex incorporated into the filter for higher temperature operation. Special media developed by Flanders for one customer, Rocky Flats, with more stringent requirements than standard at the time (approximately 9 years ago in the early 1980s). This filter would have met all nuclear grade standards at the time.

b. What would a Pack Type of " $F$ " be?

Flanders Response: Today this is considered an industrial grade filter but prior to 1996, it may have been classified as a Nuclear Grade HEPA Filter. For the specific models T-007-F-03-05-NU-51-23-GGF-U5, T-007-F-03-05-NV-51-GGF-U5, and T-007-F-03-NU-51-23-GGF-U5, these were Nuclear Grade HEPA filters at the time of manufacturer.

c. Any information on how MIL Standard 51068 and MIL Standard 51079 may have been incorporated into ASME AG-1?

Flanders Response. ASME AG-1 has incorporated the two MIL Standards 51068 and 51079 into Section FC and Appendix I. The Army quit maintaining these standards in 1995 . MIL Standard 51068 was a construction standard for HEPA filters. MIL Standard 51079 was a construction standard for the HEPA filter media only.

\section{Additional Questions For Flanders Generated After Conversation To Clarify Flanders Responses - 6/4/02}

1. Is there a "Structural Operating Pressure" for Flanders HEPA filters? 
Flanders Response: 10 inches water gauge maximum.

2. Do all Flanders Nuclear Grade HEPA filters have waterproofing applied?

Flanders Response: Yes.

3. If so, has Flanders used this waterproofing on Nuclear Grade HEPA filters for the last 30 years?

Flanders Response: Yes, to their knowledge. All personnel from the early days are now gone, but it is believed that waterproofing of filter media has been done since the beginning, up to 30 years ago.

4. If not, when did Flanders start applying waterproofing on Nuclear Grade HEPA filters?

Flanders Response: NA, Flanders believes they have always used waterproof filter media.

5. Flanders has stated that additives can be added to accommodate hydro-fluoric and nitric acids up to $5 \%$. Is this $5 \%$ by weight or volume?

Flanders Response: Mostly like by volume.

\section{Listing of Additional Supporting Documentation From Flanders}

1. Fire-retardant solid urethane - Manufacturer documentation for $200^{\circ} \mathrm{F}$ continuous operation

2. RTV silastic silicone - Manufacturer documentation for $450^{\circ} \mathrm{F}$ continuous operation

3. Neoprene - Manufacturer documentation for $200^{\circ} \mathrm{F}$ continuous operation

4. Silicone sponge - Manufacturer documentation for $450^{\circ} \mathrm{F}$ continuous operation

5. Glass packing - Manufacturer documentation for $1000^{\circ} \mathrm{F}$ continuous operation

6. BLU-JEL (C) Seal - Manufacturer documentation for $392^{\circ} \mathrm{F}$ continuous operation

Flanders Response: Checking with Flanders engineering department but these temperatures may be listed on MSDS sheets. See Appendix H for Flanders response to this question.

\section{Discussions With Flanders August 2002}

From: Eric_J_Berglin@RL.gov

Sent: Monday, August 19, 2002 4:47 PM

To: Maynor Dykes

Cc: cwinstead@csc.flanderscorp.com

Subject: HEPA Filter Questions

Maynor,

1. Does Flanders specify a minimum flow rate for their HEPA filters? 


\section{RPP-11413 Rev. 1}

From: Maynor Dykes [mailto:mdykes@ffi.flanderscorp.com]

Sent: Monday, August 26, 2002 7:40 AM

To: 'Eric_J_Berglin@RL.gov'

Subject: RE: HEPA Filter Questions

Question 1 - No manufacturer specificies a minimum flow rate on their HEPA filters. This is taken care of with what is called the "two flow" test (100\% and $20 \%)$. When test are made at $20 \%$ it is a very severe test and if the filters pass this test, most likely they will pass test at even lower flows. 
RPP-11413 Rev. 1

This page intentionally left blank.

: 


\section{RPP-11413 Rev. 1}

\section{APPENDIX F}

\section{DISCUSSIONS ON BREATHER FILTERS WITH}

HANFORD SITE ENGINEERING STAFF, JULY 2002 
RPP-11413 Rev. 1

This page intentionally left blank. 


\title{
DISCUSSIONS ON BREATHER FILTERS WITH HANFORD SITE ENGINEERING STAFF, JULY 2002
}

\begin{abstract}
Following are applicable excerpts from Mr. Eric Berglin's discussions with Ed Dalpiaz June 13, 2002 starting at 9:30 am and Terry Kaiser around 10:00 am.. Items that have been added for clarification to the reader but are not part of the exact original message are shown in italics.
\end{abstract}

In the essence of clarifying some of the stated requirements and basis for HEPA BREATHER FILTER in the OSDs and state reference materials, Mr. Eric Berglin conversed with Mr. Ed Dalpiaz a Design Authority (DA) in Hanford Tank farm ventilation systems and Terry Kaiser, System Engineer in Hanford West Tank Farms. The reference materials are:

1) OSD-151-T-00015, 2002, Operating Specifications for Miscellaneous Facilities, Rev. B16, CH2M HILL Hanford Group, Inc., Richland, Washington. (Hanford Intranet: ILAptfpg031webproc $\mid$ Technical 1 OSD $\mid$ Controlled $\mid O S D-T-151-00015 C . p d D$ specifically section 6.0.

2) Calculation from WHC-SD-WM-TI-352 Rev. 1 in Appendix $N$.

1. Section 6.1 of reference 1) above states "Violations of these limits will cause filter damage which could release radionuclides into the atmosphere." However, the stated limit is "1.6 inches water gauge @ 160 cfm." In addition, the Technical Basis states "See WHC-SD-WM-TI-352. Breather filters $(12 \times 12 \times 11.5)$ are rated at $160 \mathrm{cfm}$. Specification limits are $100 \%$ over vendor specifications for a new filter at these airflows to allow operating room." (See attached calculation from WHC-SD-WM-TI-352 for Breather Filters). All other HEPA filter requirements for protection from failure are, we using 4.0 and 5.9 inches of water gauge to protect against failure.

a. Is 1.6 inches of water gauge justified for protection of filter damage on passive systems verses active systems? Discussion with Terry Kaiser suggest that these breather filters are typically replaced about every 5 years due to filter gasket failure brought about by exposure to outside environmental conditions; primarily temperature. Based on this information, it appears that even though the 1.6 inches water gauge is conservative compared to the limit set on the other HEPA bases, it may be acceptable since it has had little consequence in actual operation.

b. The industry standard for replacement of HEPA filters is 2 times the original clean pressure drop as stated by this calculation. However, $80 \%$ of the HEPA filters used are in a clean room environment and hence, do not have much contamination buildup due to the clean environment they operate in. Can this same requirement be justified for Hanford Site filters? Yes, based on the above information from Terry Kaiser, these breather filters in operation are not clogging up. In addition, these filters are typically operating a very low flow rates. The nominal pressure differential is zero since these are passive systems designed to equalize the pressure between the tank and the outside environment with a resulting very low flow rate. 
c. Could this lower limit be justified to assure filter is not clogged (i.e. doesn't allow the tank to breathe) and not filter damage? Yes, based on (b) above.

2. Application of HEPA Breather Filters

a. Are these breather filters used on anything other than SSTs? Yes.

b. If so, where are they used? Primarily Double-contained receiver tanks (DCRTs), and Catch Tanks.

c. For any system where breather filters are used, what is the justification / calculation for the $160 \mathrm{cfm}$ flow rate? Just the rating of the HEPA filter. As far as the application, the actual flow rate is believed to be much below this $160 \mathrm{cfm}$, however, no basis has been found for the range of flow through the Tank Farm tanks for these HEPA systems at this time. In Procedure 3-VBP-157, the in-place testing uses a range of 35 to $100 \mathrm{cfm}$ using a flow imposed by a low flow test fan.

3. Testing if HEPA Breather Filters

a. How are these filters tested in-place at (i.e. what generates the test flow if these are passive systems? Using a portable fan per procedure 3-VBP-157. A port is provided for hooking up a fan and hose to do testing while the tank is valved out from the filter pathway.

b. A portable vacuum? No, a portable fan is used.

4. Breather Filters

a. Are all breather filters HEPA filters? Yes.

5. In the Detection/Control section, it states "A tank pressure relief loop seal attached to the breather filter assembly is set to relieve at 4 in wg."

a. What is the justification for this 4 inches water gauge seal loop relief? Per Terry Kaiser, justification comes from the Dome Load Assessment in the FSAR with a 6-inch water gauge limit. The seal loop limit is $33.33 \%$ below the tank limit in the FSAR and will prevent the tan $\mathrm{k}$ from every reaching 6 inches water gauge. The seal loop fluid is Dow Corning 200 Silicone fluid with a specific gravity near 1.0 per Tank Farm Procedure TO-060-015 "Monitor Waste Storage Tank Oil Seal Loop and Change out Breather Filters."

6. In the Recovery section, it states "If the test efficiency is less than $90 \%$, the isolation valve shall be closed to separate the filter from the SST and the seal loop must be observed daily (unless hooked up to another HEPA filter system through a cascade line) until the filter is replaced and the valve is reopened."

a. What is being observed/verified on the seal loop? Presence of sufficient liquid in trap.

b. What is the action if the seal loop limits are exceeded? Action per procedure TO060-015 "Monitor Waste Storage Tank Oil Seal Loop and Change out Breather Filters" is to replace the fluid and notify the shift supervisor. Per Terry Kaiser, the seal fluid on these breather filters has been blown out completely and the tank 


\section{RPP-11413 Rev. 1}

is open to the atmosphere. Per Terry, any time frame related to replacement of this fluid would be dictated by Environmental requirements and currently there is no engineering limit. 


\section{RPP-11413 Rev. 1}

\section{APPENDIX G}

FLANDERS FILTERS, INC. BULLETIN NO. 936D, NUCLEAR GRADE HEPA FILTERS 


\section{RPP-11413 Rev. 1}

This page intentionally left blank. 
Mr. Eric Berglin

COGEMA ENGINEERING CORP.

2425 Stevens Drive

Richland, WA 99352

Dear Mr. Berglin:

Confirming our recent conversation, we are pleased to provide this release of information letter, conveying our consent for your including our Bulletin No. 936D Nuclear Grade HEPA Filters within the Appendix portion of your report.

If you have any questions or require further assistance of any kind, please do not hesitate to contact us.

Kind Regards,

FLANDERS FILTERS, INC.

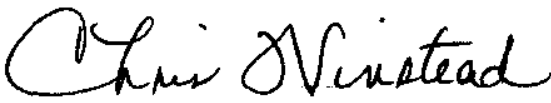

Chris Winstead

Containment HEPA Sales

c: $\quad$ Mr. Glen Moore, National Sales Manager Containment Products 
RPP-11413 Rev. 1

This page intentionally left blank. 


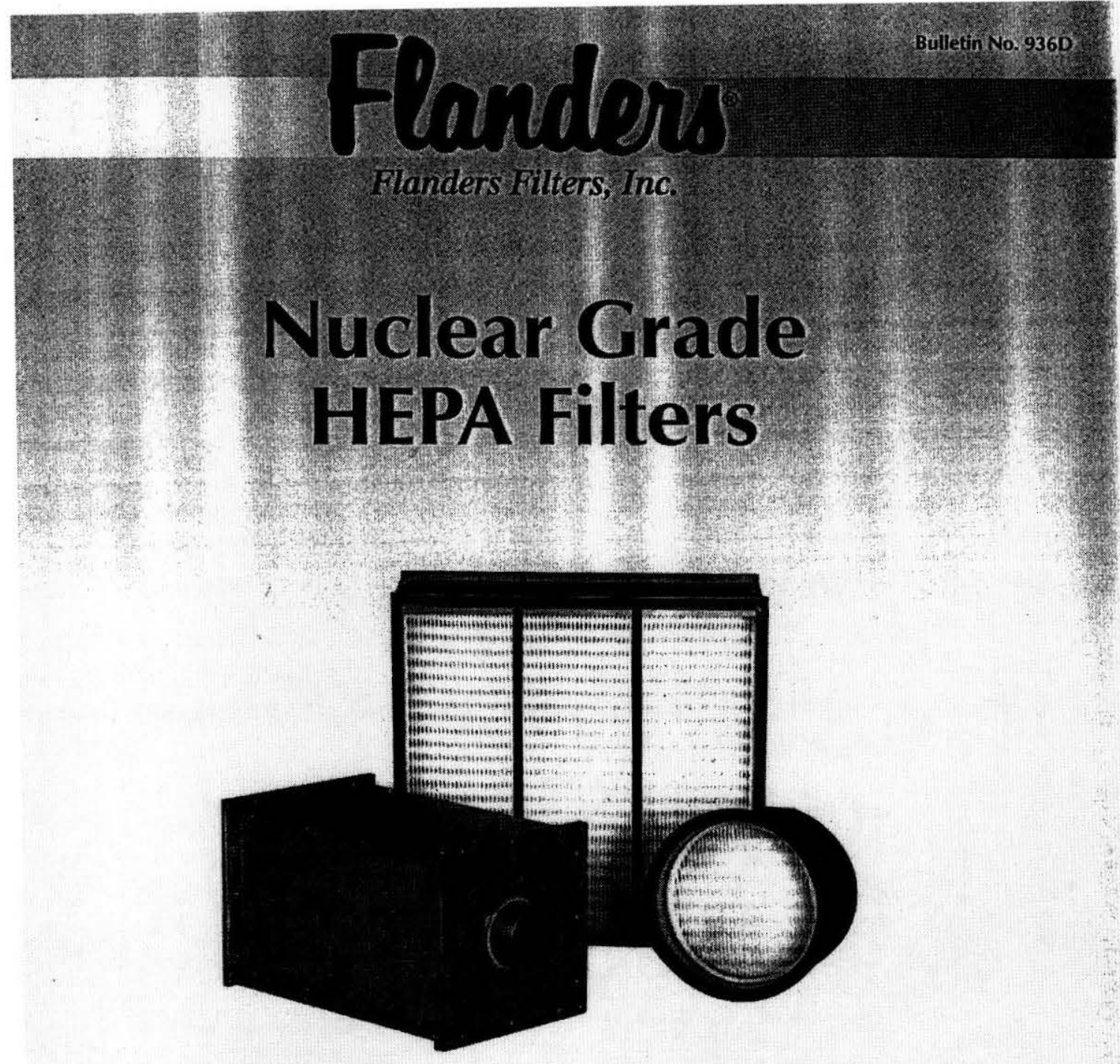

Rectangular, Square, Round, and Nipple-Connected Type B Filters Constructed and Tested in Accordance with MIL-STD-282 \& IES-RP-CC-001.3 
RPP-11413 Rev. 1

This page intentionally left blank. 

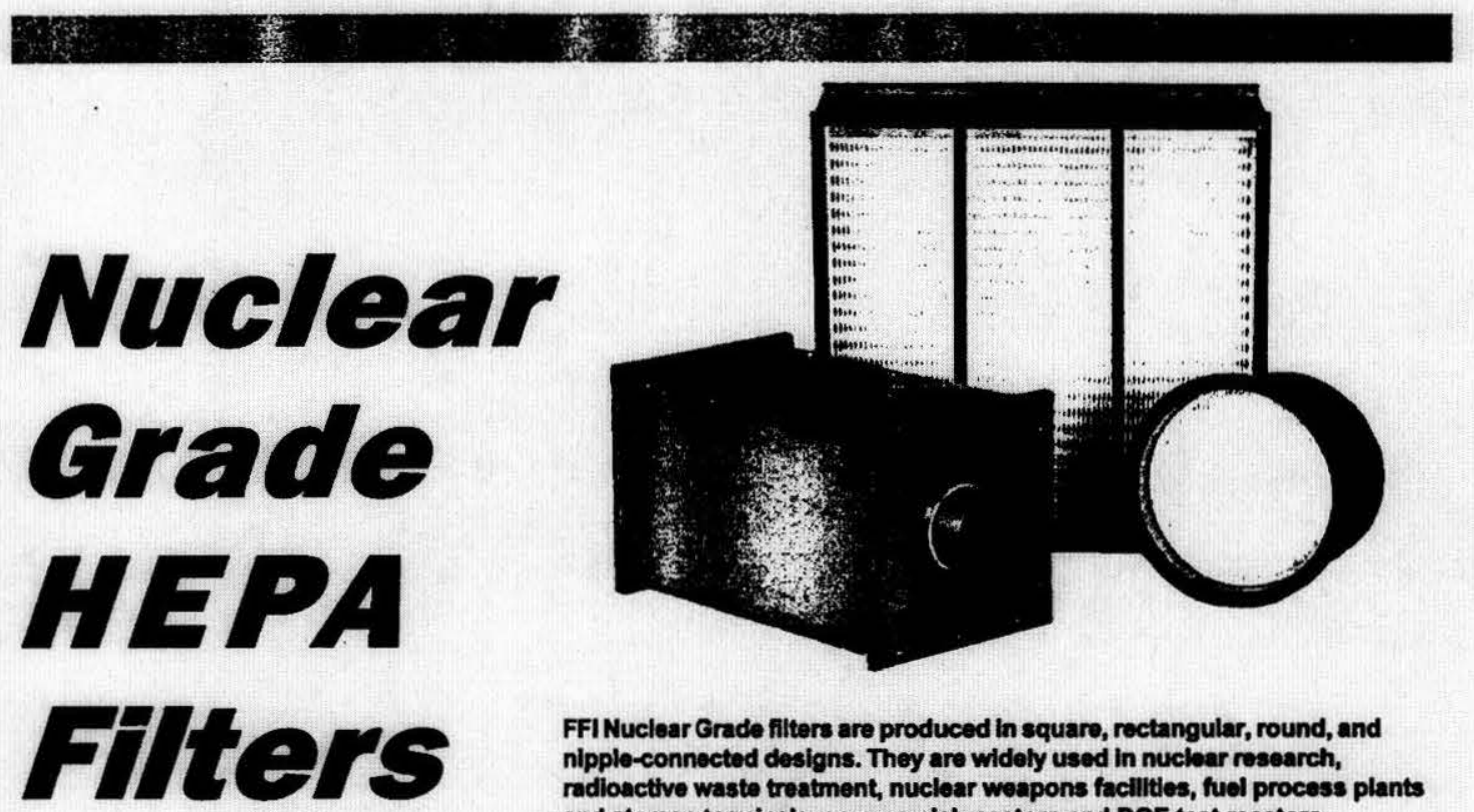

FFI Nuclear Grade filters are produced in square, rectangular, round, and nipple-connected designs. They are widely used in nuclear research, radioactive waste treatment, nuclear weapons facillites, fuel process plants and storage terminals, commercial reactors and DOE test reactors.

Flanders Filters, Inc. (FFI) Quality Assurance FFI's Quality Assurance Program meets the requirements of ANSI/ASMENOA-1 and 10CFR5O APPENDIXB.

\section{Comprehensive Factory Testing}

Every FFI Nuclear Grade HEPA filter is tested for penetration and resistance to airflow at $100 \%$ and $20 \%$ of their rated flow prior to shipment. The lower flow test ensures that there are very few defects in the filter. The maximum penetration allowed at either flow is $0.03 \%$. In recent years, HEPA filter designs have been developed that exceed the original test method's flow capacity. Therefore Flanders uses one of two different test methods to ensure the quality of Nuclear Grade Filters. They are describedbelow.

The test method which has been historically specified and is used by Flanders for most Nuclear Grade filters is MilStd 282 (method 102.9.1). In this test an approved oil aerosol is used to generate a nearly monodisperse aerosol of approximately 0.3 micrometers diameter droplets. The penetration of the aerosol through the filter is measured with a forward light scattering photometer. The instrument specifed by Mil-Sid 282 is known as a Q-107 penetrometer. It was originally developed by the U.S. Army prior to 1950 . The instrument is limited by its design to testing at flows from $15 \mathrm{~cm}$ to $1100 \mathrm{cfm}$. Flanders uses this instrument for all Nuclear Grade filters with rated flows from $75 \mathrm{~cm}$ to $1100 \mathrm{cfm}$. Below $75 \mathrm{~cm}$, the $20 \%$ flow test cannot be performed.

An alternative test method was developed in the 1980's by Los Alamos National Laboratories under contract to the U.S. Department of Energy. It is often referred to as the HFATS test for High Flow Alternative Test System. It was developed specifically to test filters which are rated at flows higher than $1100 \mathrm{cfm}$ although it can be used for lower flows also. It is only limited by the size of the system fan and aerosol generator output. This method was later standardized in the publication of a recommended practice IES-RP-CC-007.1 "Testing ULPA Filters" by the Institute of Environmental Sciences. Currently ASME AG-1 section FC allows for testing by this method. It challenges the filter with an acceptable polydisperse oil aerosol and measures the penetration through the filter with a Laser Particle Counter. The Particle Counter counts and sizes individual droplets in size ranges from around 0.1 to 3.0 micrometers in diameter. The ratio of the downstream counts to the upstream counts in each size range is the penetration. Although this value is not equal to the penetration measured by the Q-107, the research done at Los Alamos proved it to be very similar and an acceptable alternative to the penetration measured by Mil-Std 282 Test Method. 
Since the system measures the penetration of each size range, and a HEPA filter penetration varies with particle size, the maximum allowable penetration is $0.03 \%$ for the most penetrating particle size (MPPS). FFI uses this system to test filters which are rated at flows higher than $1100 \mathrm{cfm}$.

\section{Retesting by DOE Filter Test Facilities}

Some nuclear facilities operated for DOE require that their HEPA filters be retested at the Filter Test Facility operated for DOE. This service must be purchased by the buyer. Filters which are rejected at the test station as not conforming to the purchase specifications, and which are determined not to have been damaged in shipment, will be replaced at no cost to the buyer. Filters must be shipped directly from the factory to the retest facility. If filters must be shipped to a retest facility, this requirement must be specified when quotations are requested. Fitters requiring retest will be quoted and sold to end user only.

\section{Design Qualification Tests}

Design qualification testing is a key element of Nuclear Grade filters. Since there is a wide variety of filter types, sizes, and construction materials, purchasers should make it clear what design qualification tests are required in any solicitation. These tests can be included but may not be limited to those specified in ASME AG-1 Section FC.

| Those tests are defined only for $24^{\prime \prime}$ by $24^{\prime \prime}$ by $11.5^{n}$ square filters and may not be applicable to the round and nipple-connected filter designs. AG-1 requires the design qualification tests to be performed by an independent laboratory within the past 5 years of shipment.
Flanders has several models which meet these requirements; please consult the factory for the latest list of models which do. In addition, Flanders has the capability to perform several of these qualification tests in-house under the Flanders quality assurance program. These tests may be helpful to the purchaser to qualify designs which do not meet the full requirements of ASME AG-1. Please consult the factory for assistance in this matter.

\section{Selsmic Qualification}

ASME AG-1 requires filters to be seismically qualified and the purchaser must specify the loading to be applied. FFI has qualified various filter models per ASME AG-1 Section FC4300. The test qualification was performed as follows. A HEPA filter was installed in a FFI bag-in bag-out containment housing and subjected to simulated earthquake loading. No failure or damage was observed during or subsequent to the simulated event which exceeded the current requirements for UBC Zone 4 loading.

\section{Testing Service Avallable}

Flanders service personnel are available for installation, supervision of installation, filter testing and certification of compliance to industry and government standards, and instruction of the owner's personnel intesting and maintenance procedures. Contact the factory for details.

\section{FIIter Design and Construction}

\section{Filter Media}

The filter media in FFI's Nuclear Grade filter elements is glass (boron silicate microfiber) and contains a waterproofing binder which adds strength under both wet and dry conditions. FFI manufactures its own filter media to meet or exceed the requirements of
MIL-F-51079 (latest issue) and/or ASME AG-1 Section FC, Article 1-3000. FFI '007' media is currentily listed on the U.S. Army Qualified Products List QPL 51079. This media meets the requirements of ASMEAG-1 Section FC, Article 1-3000. QPL-approved media which have been formulated for resistance to airborne acids are also avallable; consult the factory. 


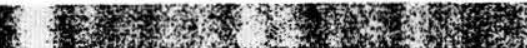

\section{Two Types of Filter Pack Designs}

Flanders Filters manufacturers conventional Separator Style and Pureform@ Separatorless Hepa Filters. In a Separator Style, the filter media is folded over corrugated aluminum separators with hemmed edges to separate the pleats in the filter pack. Flanders Filters manufactures its own filter media, which has enabled us to develop a unique manufacturing process for the production of PUREFORMO Separatorless HEPA Filters. In one manufacturing operation, Flanders Filters produces a self-supporting and self-separating PUREFORMOMedia Pack. The PUREFORMO Filter offers many advantages over conventional Separator Style HEPA Filters:

- More usable media area for longer service life due to highers dust holding capacity

- Reduced cost of ownership due to longer service life

- Maximum utilization of the media

- $11^{\prime \prime}$ deep PUREFORMO Pack has $261 \mathrm{sq}$. $\mathrm{ft}$. of media as compared to $225 \mathrm{sq}$. ft. for a conventional separator style filter.

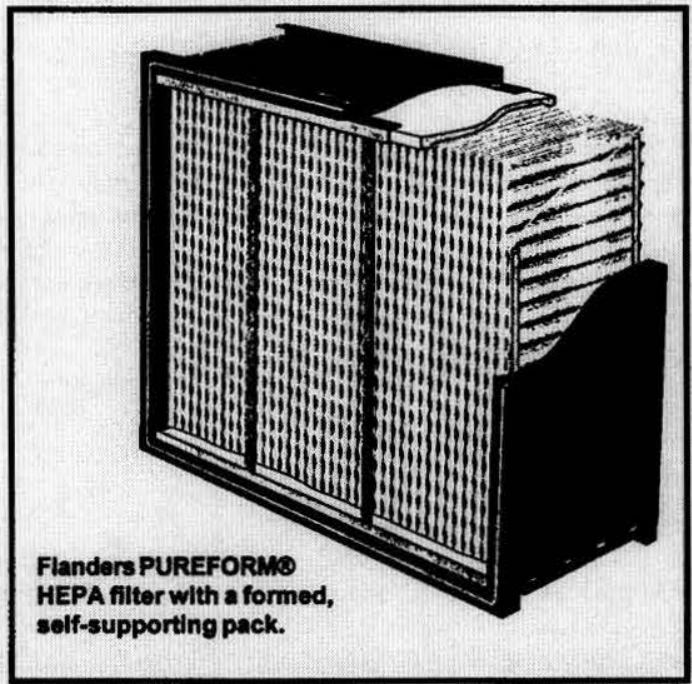

- Can handle some harsh environments which may attack aluminum separators

- Media pack can be incinerated

- Media is significantly thicker (28 mils) than conventional media used in Separator Style HEPA Filters (15 mils)

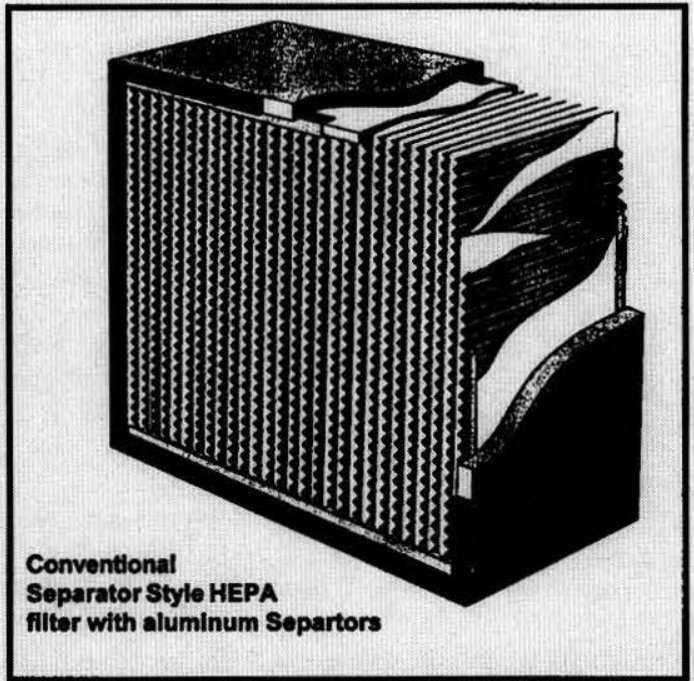




\section{Sealants}

Fire-retardant solid urethane is used to bond the filter element to its integral frame. Maximum temperature rating for these sealants is $250^{\circ} \mathrm{F}$.

\section{Frame Material}

Plywood-Fire-retardant plywood frames are ideal for many applications, and are easier to incinerate or breakdown for disposal than are metal frame filters. However, they are not recommended for use in systems having highmoisture content or high temperature, since they may warp or support biological growth. Stainless steel frame materials should be used in moisture-laden applications.

Stainless Steel - Type 409 and Type 304 stainless steel frames are also available. The Type 409 stainless steel is used in place of the cadmium-plated and chromized steel that was used in the past. However, since the Type $\mathbf{4 0 9}$ material has a low resistance to caustic atmospheres, the Type 304 stainless steel is recommended for those applications.

\section{Frame Style}

\section{The Finld Seal}

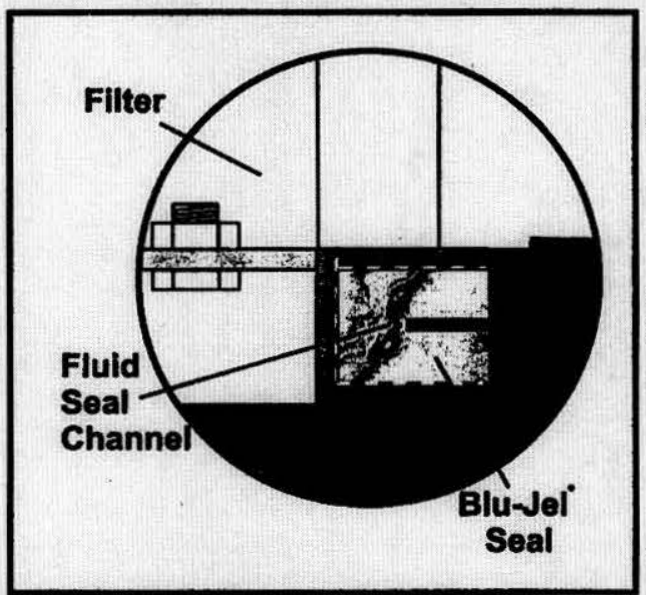

A knife edge in the filter housing mates into a fluidfilled channel provided on the filter. Flanders invented the fluid seal in response to requirements for an absolute seal in the most critial applications. In most cases, fluid seal filters are also easler and quicker to change out than gasketed filters.
The technique to be used to seal the filter in service determines the selection of the filter frame style. (See illustrations below.)

Fluid Seal - Metal frame fluid seal filters have a fabricated channel ( $\left(3 / 4^{n}\right.$ wide $x^{3} / 4^{*}$ deep) located on one face. Wood frame filters have a routed channel $\left(2 / \%^{\prime \prime}\right.$ wide $x^{3 / 4^{\prime \prime}}$ deep) on one face.

BLU-JEL' Seal was developed by Flanders' and is the standard fluid seal material.

For complete information on BLU-JEL Seal, see Date Sheet 86010 .

Gasket Seal - Metal frame gasketed filters are provided with one or two flanges for the placement of the gasket as specificed by the customer. On wooden frames, the gasket is applied to the face of the frame.

Gasketed filters for normal service are supplied with either closed cell sponge neoprene or Cohrlastic silicone sponge gaskets $\left(1 / 4^{n} x^{3} / 4^{n}\right)$. High-temperature filters require the special sealants described on page 9. Specily upstream, downstream, or both for the location of the gasket or fluid seal in the model number.

\section{The casket Seal}

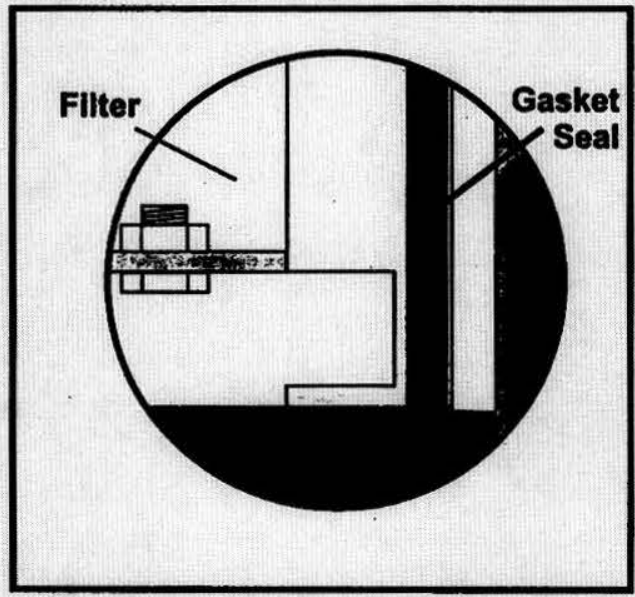

A filter clamping mechanism Is typically used to maintain sealing pressure on gasketed filters. Gasket seals have a tendency to develop bypass leaks, primarily because of compression sot. 


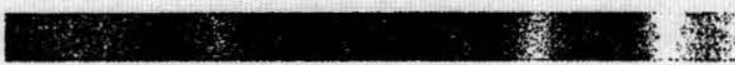

\section{Faceguards}

The standard faceguard is $4 \times 4$ mesh, 23-gauge, welded galvanized dipped steel. Type 304 stainless steel faceguards ( $4 \times 4$ mesh, 18-gauge woven wire or 22 gauge welded wire) are also available for highly-corrosive atmospheres. Faceguards protect the media, but are not a guarantee against damage due to mishandling.

Specify faceguard location as upstream, downstream or both.
Underwriters Laboratory, UL 586

To be listed under UL 586, filters must be submitted to Underwriters Laboratories for extensive testing including spot flame, and environmental exposure to heated air. A UL 586 listing is accepted by the DOE as meeting the Heated Air requirement in ASME AG-1 for Nuclear Grade filters.

UL labels are optional. Some high-temperature filters, and fitters larger than $24^{\prime \prime} \times 30^{\prime \prime} \times 11 \% "$ ", are not eligible for UL 586 .

\section{Notes on Fliter Selection}

- Standard PUREFORMO maximum height is $24^{n}$. When specifying non-standard filter size, the first dimension is always the height of the filter (the dimension parallel to the pleat of the medium); the second dimension is always the width of the filter, and the third dimension is the filter depth.

- The filter sizes included in the original military standards have not been expanded to include all of the sizes offered by manufacturers or requested by users today. A principal reason for this is the inherent physical weakness of the larger sizes. Filters larger than $24^{\prime \prime} x$ $24^{*} \times 11-1 / 2^{n}$ should not normally be used in nuclear service (although some older installations do have larger filters which must be resupplied) or in any application where human health could be threatened.

- Of the five sizes appearing in the original specifications, the GG-F and GG-D are the largest. Capacities for other sizes are computed from one of these two, depending on the filter element depth of the unlisted fitter and its effective face area relative to the listed size. (The face area is obtained by subtracting two inches from the height and width dimensions to allow for the thickness of the frame and the glue line.)

011-1/2" deep filters are generally selected for senvice where a minimum amount of space relative to a maximum amount of airflow is required. Most often this is required in built-up banks, walk-in plenums, or side-access housings. Flanders' GG-F size filter is most frequently selected.

- When operated at higher flows efficiency will decrease and resistance will increase. Care should be taken when planning to operate a filter at higher than the rated capacity to determine if hostile environmental factors, such as combined high operating flow rate, water vapor condensation, and/or acid vapors, will cause filter failure. For example, water condensate on the filter media could plug the element, causing failure. 


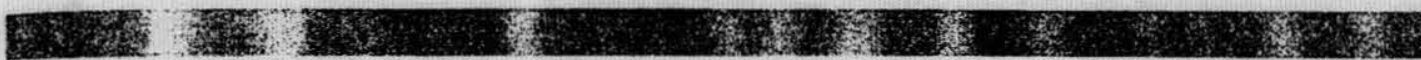

, Standard Sizes and Capacitles

Flandersmanufacturesstandard square and rectangular Nuclear Grade fitters in a variety of sizes and capacities.

(Sizes and capacities for Round and Nipple-Connected fitters are listed in their respective sections in this bulletin.) The type (PUREFORM ${ }^{m}$ or separator-type) and depth of the filter element is a primary factor in filter capacity.

NOTE: The maximum allowable resistance at the Nominal

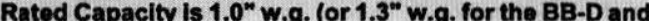
CC-D sizes).

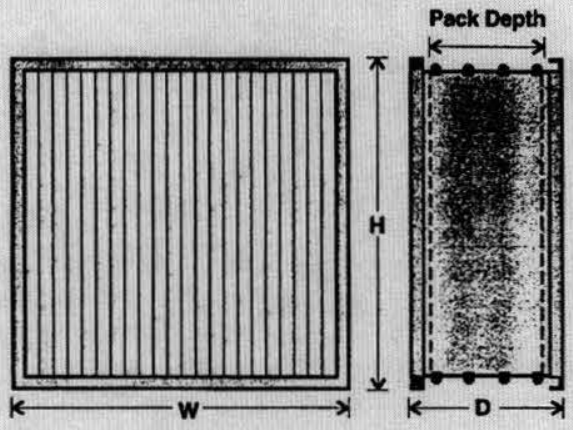

11" PUREFORM Filter Element

$\begin{array}{lll}\text { FILTER SIZE } & \text { DIMENSIONS } & \text { CAPACITY MAXINIT. } \\ \text { DESIGNATOR } & \text { H W D D } & \text { (CFM) RESISTANCE }\end{array}$

\section{1" Separator-Type Filter Element}

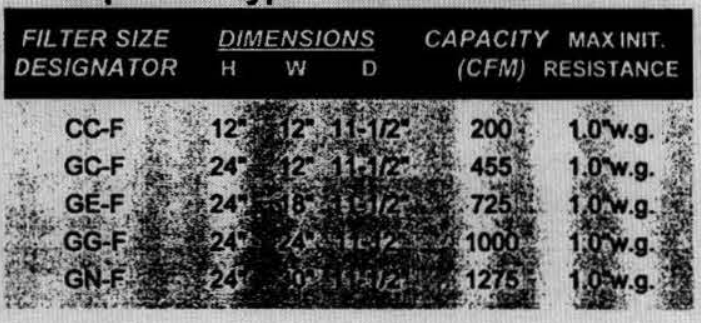

\section{5-1/2" Separator-Type Filter Element}

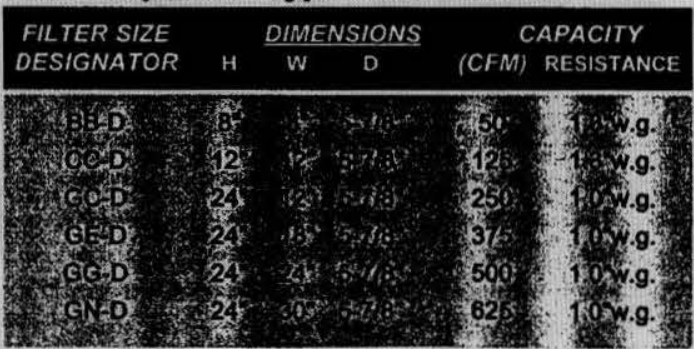

4" PUREFORM Filter Element

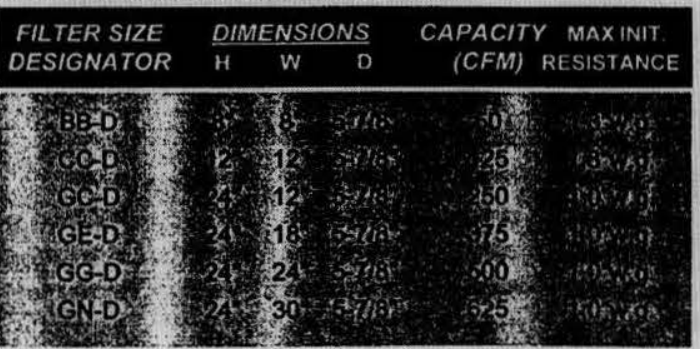

200 16.0\%, 455 7.0. 


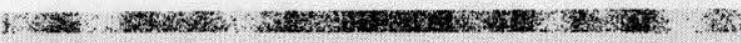

\section{Standard PUREFORM ${ }^{\text {IM }}$ FIIters}

Insert the desired Filter Size Designator from the charts on page 6 at the end of the model number (for example, T-007-W-02-05-NU-51-13-GG-FU5). Typical model numbers specifying filters with galvanized or stainless steel faceguards on both faces and with either BLU$\mathrm{JEL}^{\circ}$ Seal or a neoprene gasket located on the upstream face are addressed below.

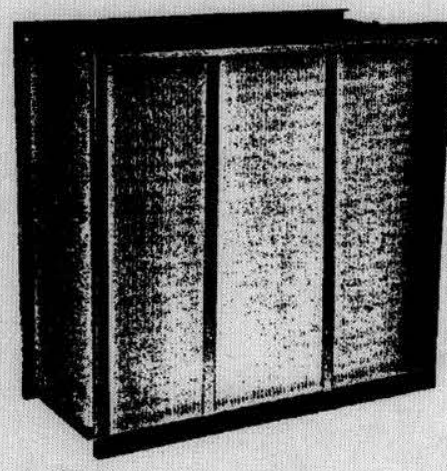

Fluid Seal Filters

\begin{tabular}{|c|c|c|}
\hline $\begin{array}{l}\text { DEPTH OF } \\
\text { ELEMENT }\end{array}$ & $\begin{array}{l}\text { FRAME } \\
\text { MATERIAL }\end{array}$ & $\begin{array}{c}\text { FILTER MODEL NUMBERS } \\
\text { (Typical) }\end{array}$ \\
\hline & Type 409 S/S & 53. 74 \\
\hline \multirow[t]{3}{*}{$4^{n}$} & Type 304 S/S & $T-007-0-43-05-N U-51-23$ \\
\hline & 3/4" F.R. Plywood & T-007-D-04-05 NUS1-13_ \\
\hline & Type 409 S/S & $T-007-W-42-05$ NU $-51-53$ \\
\hline \multirow[t]{2}{*}{$11^{\prime \prime}$} & Type 304 S/S & $T-007-W-43-05-N U-51-23$ \\
\hline & 3/4" F.R. Piywood & T-007-W-04-05-NU-51-13- \\
\hline
\end{tabular}

The $T$ prefix in the model number indicates a T-clip requirement for fluid seal-type filters used in side-access housings. (See fluid seal diagram on page 4).

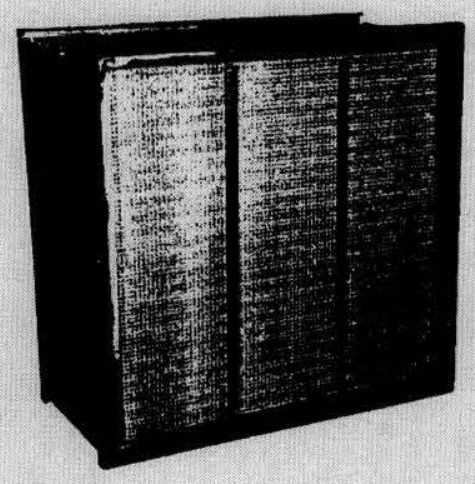

\section{Gasket Seal Filters}

\begin{tabular}{|c|c|c|}
\hline $\begin{array}{l}\text { DEPTH OF } \\
\text { ELEMENT }\end{array}$ & $\begin{array}{l}\text { FRAME } \\
\text { MATERIAL }\end{array}$ & $\begin{array}{c}\text { FILTER MODEL NUMBERS } \\
\text { (Typical) }\end{array}$ \\
\hline & Type 409 S/S & \\
\hline & Type 304 S/S & 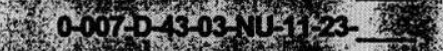 \\
\hline & 3/4" F.R.Plywood & 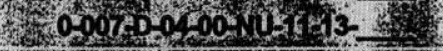 \\
\hline manar & Type $409 \mathrm{~S} / \mathrm{S}$ & 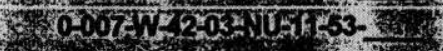 \\
\hline$x^{1} 11^{n}$ & Type 304 sis & 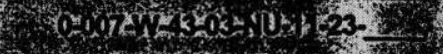 \\
\hline Whe & 0 & Sovitionion \\
\hline
\end{tabular}

\section{8 影}

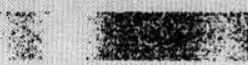




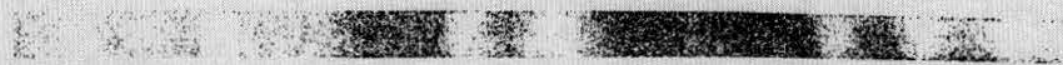 \\ Standard Separator-Type Filters}

Insert the desired Filter Size Designator from the charts on page 4 at the end of the model number. (The Size Designator indicates whether a $5-1 / 2^{\prime \prime}$ or 11 " filter element is being ordered.) Typical model numbers specifying filters with galvanized or stainless steel faceguards on both faces and $\mathrm{BLU}^{-\mathrm{JEL}^{\circ}}{ }^{\circ}$ Seal or a neoprene gasket located on the upstream face are addresses below.

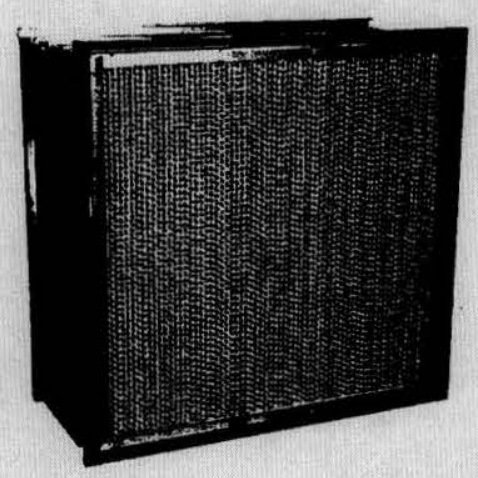

Fluid Seal Filters

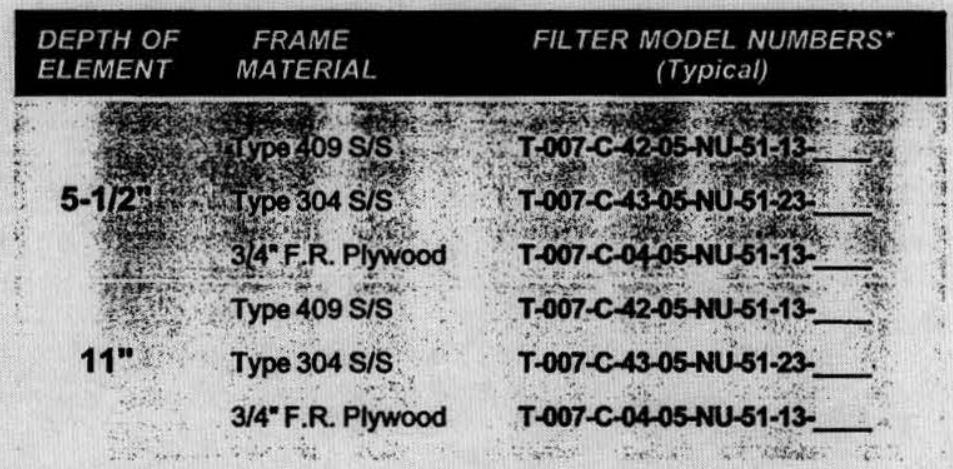

The ' $T$ ' prefix in the model number indicates the required $T$-clip for fluid seal type filters used in side-access housings. (See fluid seal diagram on page 4).

\section{Gasket Seal Filters}

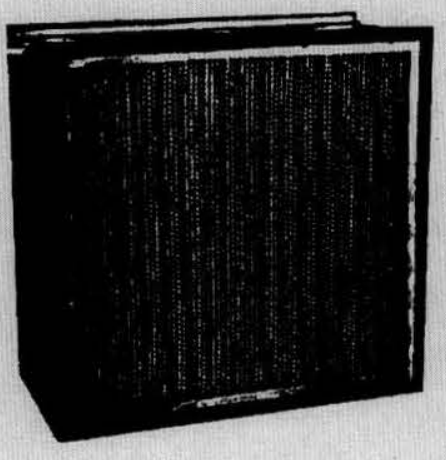

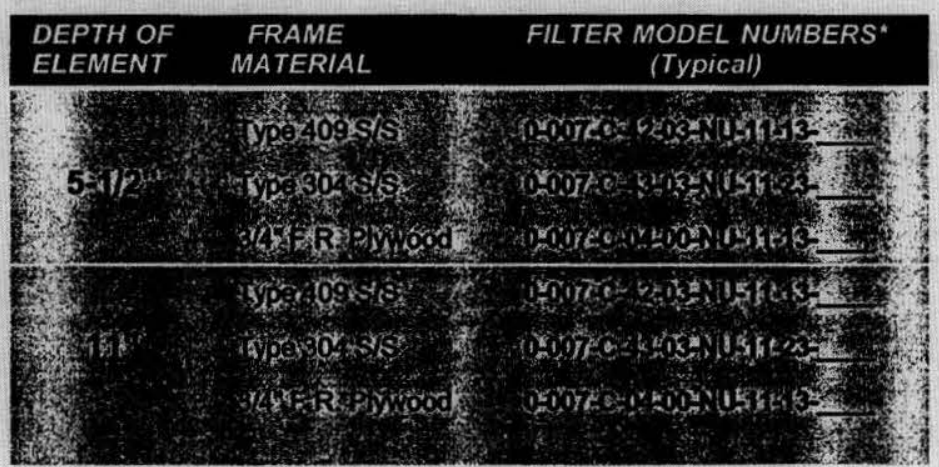




\section{Standard High-Temperature Fllters}

Flanders manufactures steel-frame separator-style HEPA filters for applications with high-temperature requirements up to $1,000^{\circ} \mathrm{F}\left(540^{\circ} \mathrm{C}\right)$ for exhaust air only and $500^{\circ} \mathrm{F}\left(260^{\circ} \mathrm{C}\right)$ for supply air. They do not meet all of the qualification requirements of ASMEAG1 Section FC, and are not eligible for UL 586 labels. High-temperature filters are available with gasket or fluid seal. (Filters with BLU-JEL' Fluid Seal have a maximum service temperature of $392^{\circ} \mathrm{F}$.)

High Temperature Nuclear Grade Filters meet the requirements of IES-RP-CC-001.3 for Type B Filters and are tested in accordance with MIL-Std-282. Two types of high-temperature HEPA filters are offered, and the choice should be carefully made in accordance with the proposed filter service requirements for the specific application.

\section{Silicone Sealant (Designator NE)}

This is a high-temperature room-temperaturevulcanizing (RTV) silastic-sealant silicone compound rated for continuous service up to $500^{\circ} \mathrm{F} / 260^{\circ} \mathrm{C}$ (supply air). NOTE: This high-temperature sealant is not UL 586 approved and does not meet all the qualification requirements of ASME-AG1 Section FC.

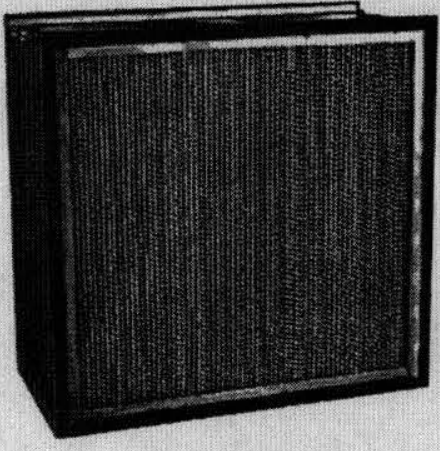

\section{Glass Pack Sealant (Designator NG)}

The glass pack seal is rated for continuous service up to $1,000^{\circ} \mathrm{F} / 540^{\circ} \mathrm{C}$ in exhaust air applications only and with separator-type filters only. It is a mat of submicron glass fibers that creates a seal when compressed between the filter pack and filter frame. The glass packing is not an adhesive seal but a mechanical seal that functions much as the glass fiber medium of the filter itself. Additional flanges are added to prevent the filter pack from slipping at high pressure drops.

NOTE: Due to the possibility that the glass pack may shed glass fibers, the glass pack sealant should be used for exhaust systems only.

NOTE: Labels are not attached to high-temperature filters

Available Filter Sizes and Capacities*

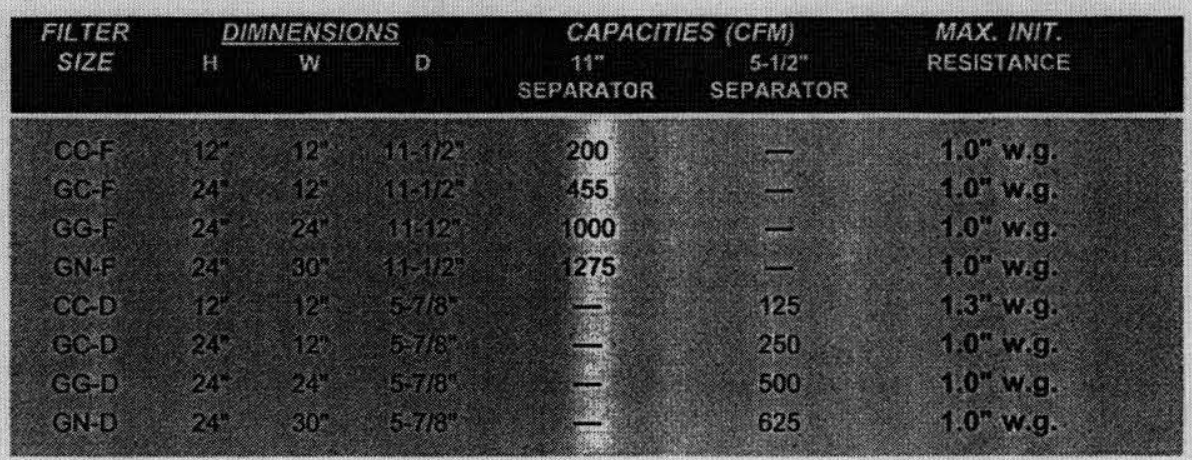




\section{Supply or Exhaust Air $500^{\circ} \mathrm{F}$ Maximum (Gasket Seal) or $390^{\circ} \mathrm{F}$ Maximum (Fluid Seal)}

Insert the desired Filter Size Designator from the chart on page 9 at the end of the model number. Typical model numbers specifying filters with galvanized or stainless steel faceguards on both faces and with
BLU-JEL Seal (for fluid seal filters) or silicone sponge (for gasket seal filters) located on the upstream face are addressed below.

\section{Separator-Type Filters}

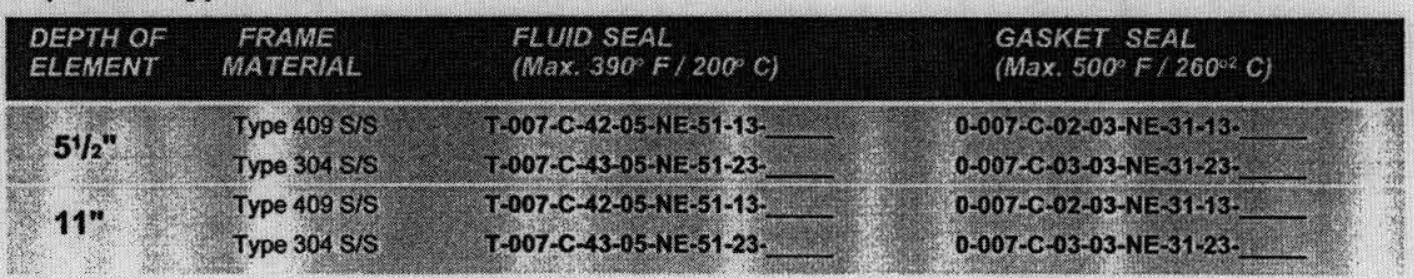

\section{Exhaust Air Only - $1000^{\circ} \mathrm{F}$ Maximum}

Insert the desired Filter Size Designator, from the charts on page 9 , at the end of the model number. Model numbers specifying filters with steel faceguards on both faces are addressed below.

\section{Separator-Type Filters Only}

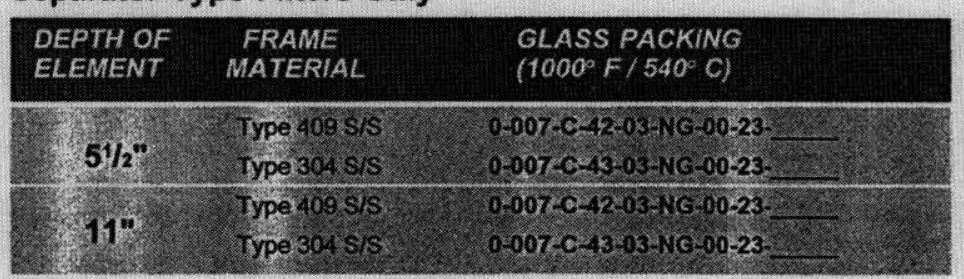

NOTE: These filters are shipped without gaskets, since none of the standard gasket materials are rated for $1000^{\circ} \mathrm{F}$ service. However, two woven glass gaskets may be provided with the filter if requested. The gaskets are shipped unattached and must be installed with the fitter. 


\section{Round Fiters}

Round Nuclear Grade filters are available with Flanders' PUREFORM@ filter element and with separator-type elements. Frames are made of Type 304 or Type $\mathbf{4 0 9}$ stainless steel, and are available for both gasket or fluid seal applications. Round filters are also manufactured for high temperature applications. (See page 9 for information on high-temperature sealants.) Round Nuclear Grade filters are made of the same materials specified in ASME AG-1 but are not tested for rough handling, wet over-pressure, or heated air as called out by that specification. Flanders performs acceptance testing of penetration and resistance only.
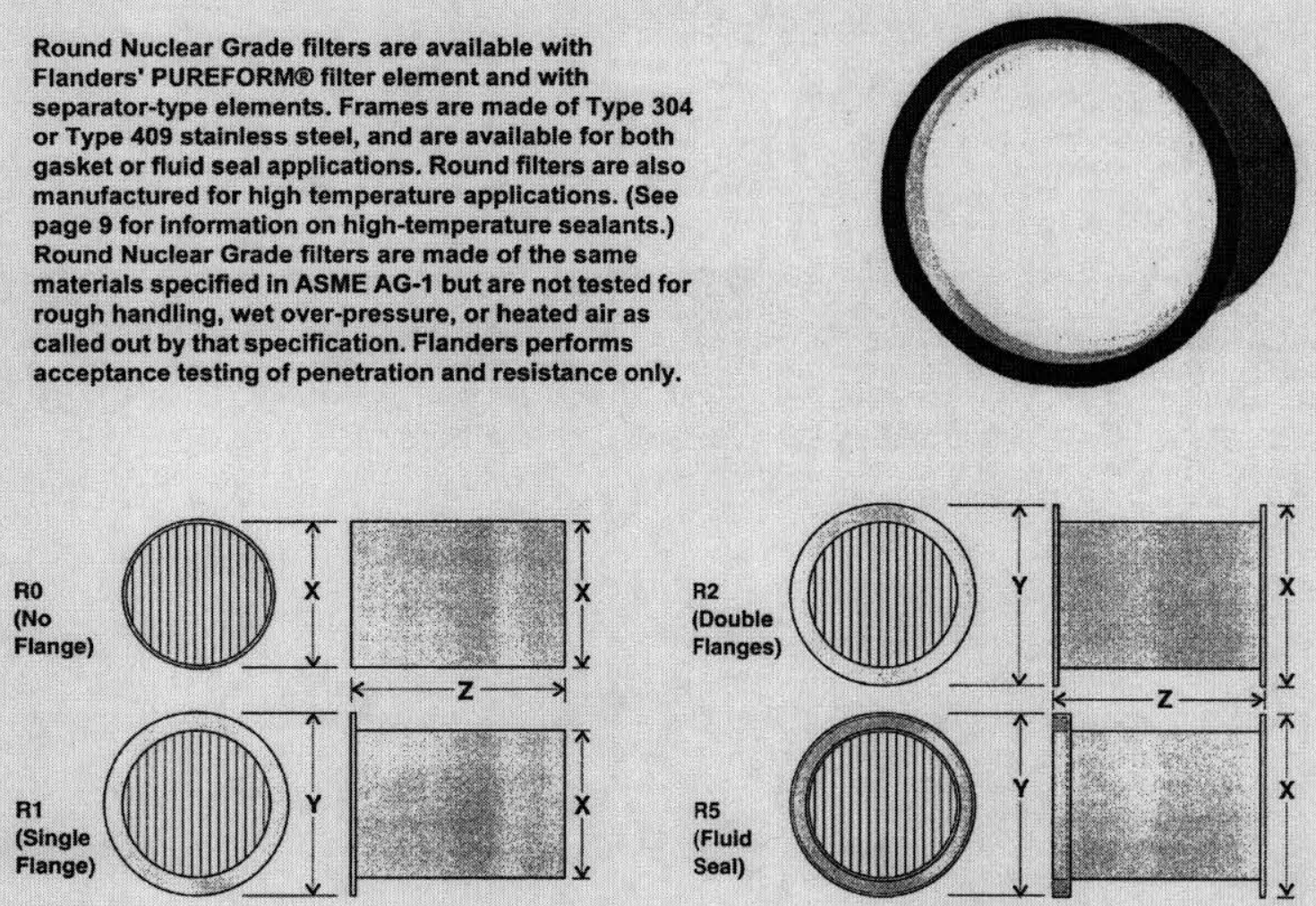

\section{PUREFORM ${ }^{\mathrm{TM}}$ Filters}

\begin{tabular}{|c|c|c|c|c|c|c|}
\hline \multirow{2}{*}{ SIZE } & \multicolumn{3}{|c|}{ DIMENSIONS } & \multirow{2}{*}{$\begin{array}{c}\text { DEPTH OF } \\
\text { EILTER ELFMENT }\end{array}$} & \multirow{2}{*}{$\begin{array}{l}\text { NOMINAL } \\
\text { RATED } \\
\text { CAPACITY }\end{array}$} & \multirow{2}{*}{$\begin{array}{l}\text { MAXIMUM } \\
\text { INITIAL } \\
\text { RESISTANCE }\end{array}$} \\
\hline & $x$ & $Y$ & $z$ & & & \\
\hline
\end{tabular}

\section{Separator-Type Filters}

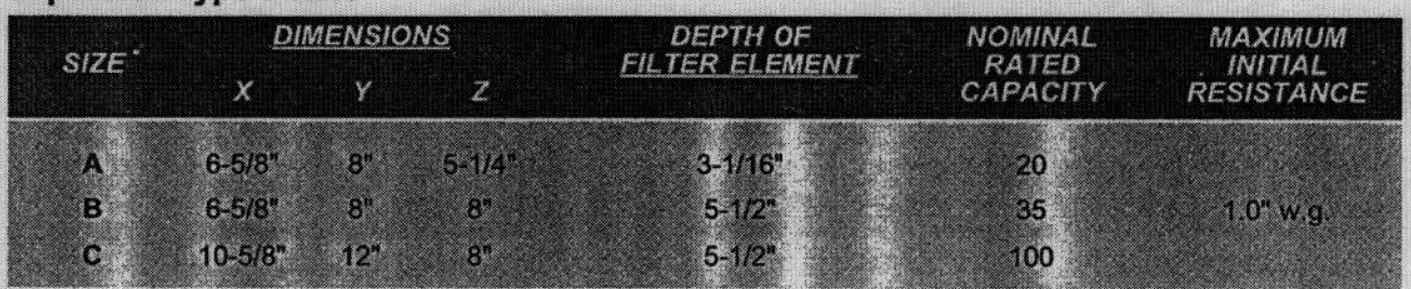


Fluid Seal

Fluid Seal filters are supplied with a $5 / 8^{\prime \prime} \times 11 / 16^{n}$ deep channel on one face only. The channel is factory-filled with Flanders' BLU-JEL SeakB fluid sealant. Use the R5 Frame Style and specify location (upstream or downstream face) of the channel in the model number.

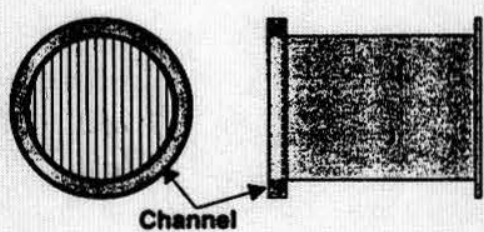

\section{Gasket Seal}

Gaskets are made from $1 / 4^{\prime \prime} \times 3 / 4^{\prime \prime}$ closed cell neoprene material. Gaskets may be located on either side of the upstream or downstream flange. Use either R1 or R2 Frame Style and specily location of the gasketed flange(s) as upstream, downstream, or both, in the model number. Write out any special placement requirements.

\section{Gasket Location}

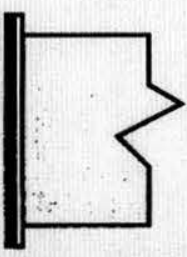

Face of Flange

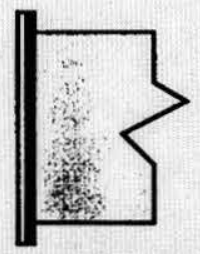

Back of Flange

\section{Lifting Bails}

Optional lifting bails are available for easy filter removal in special applications. Specify the 'B' prefix in the fitter model number.
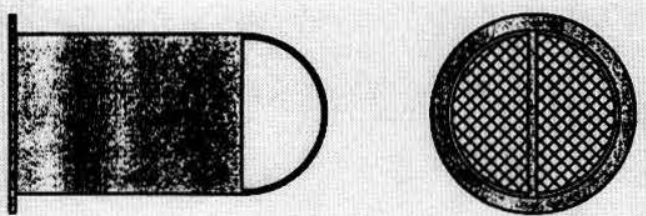

\section{Faceguards \\ Faceguards}

The standard faceguard is 4

$\times 4$ mesh, 23-gauge,

welded galvanized dipped

steel. Type 304 stainless steel faceguards $(4 \times 4$ mesh, 18-gauge woven wire or 22 gauge welded wire) are also available forhighly-corrosive atmospheres. Faceguards protect the media, but are not a guarantee against damage due to mishandling. Specify faceguard location as upstream, downstream, or both.

\section{Drilled Flanges}

Drilled flanges areavailable in a standard paltern or according to customer specification. Flanders' standard pattern is (8) $5 / 16^{\text {" diameter holes }}$ equally spaced and centered on the flange. Use the 'D' prefix in the model number and specify the location of the flange as upstream, downstream, or both.

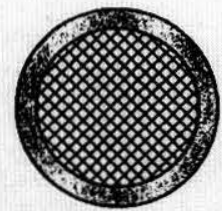

\section{UL 586}

To be listed under UL586, filters must be submitted to Underwriters Laboratories for extensive testing including spot flame and exposure to heated air. A UL586 listing is accepted by the DOE as meeting the Heated Air and Spot Flame Requirement for Nuclear Grade filters. NOTE: UL labels are optional and are applied only if specified by the buyer.

High-temperature sealants are not ellgible for UL586.

\section{Model Numbers and Specification}

To write a specification for Round Filters, use the Designating Chart on Page 16 to determine the model number. FIII in the numbered locations in the Suggested Specification Text on Page 17 with the model number and other appropriate selections from the Ilsting at the bottom of the page. 


\section{Nipple-Connected Filters}

Nipple-Connected Nuclear Grade filters are avallable with one (N1) or two (N2) pipe connections, and with separatorless PUREFORMO or separator-type filter elements. Frame materials are Type 304 or Type 409 stainless steel and $3 / 4^{\prime \prime}$ fire-retardant plywood. High temperature models are also avallable (see page 8 for information on sealants). Nipple-Connected filters are made of the same materials specified in ASME AG-1 but are not tested for rough handiling and wet over-pressure, or heated air as called out by that specification. Flanders performs acceptance testing of penetration and resistance prior to attachment of cover plates only.

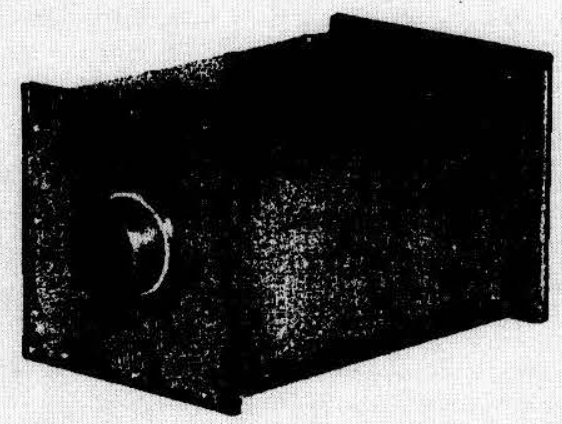

N1 Filters

TYPICAL METAL FRUME FRTER RLUSTRATED

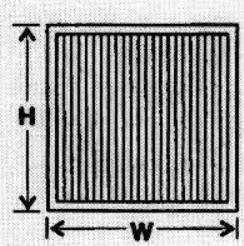

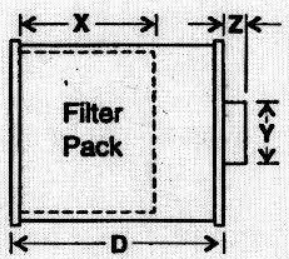

N2 Filters

TPPCAL WOOD FRAME FULTER ILUUSTRATED
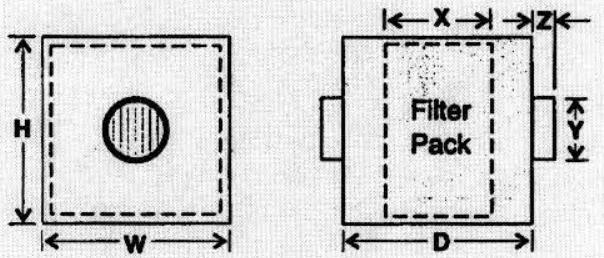

N1 or N2 Filters with PUREFORM ${ }^{m}$ Filter Elements

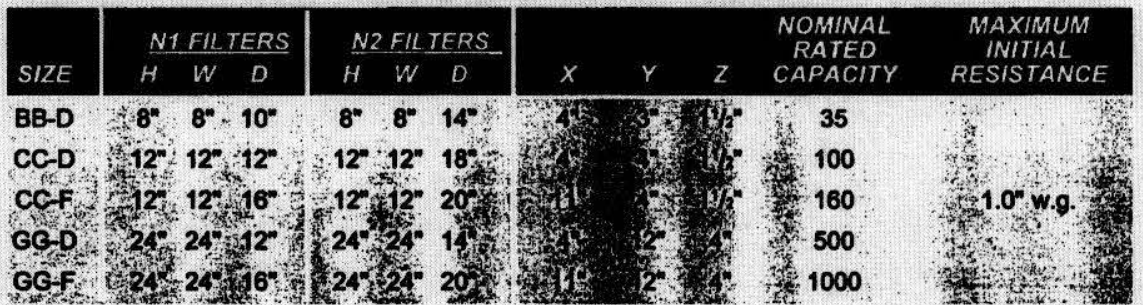

NOTE:

When ordering an N1 Filter, the customer must specily the location of the nipple (i.e. upstream or downstream).

When ordering N1 or N2 fitters, the customer should specify the size of the nipple

connections If Flanders' standard sizes (see the $r$ dimensions) are not appropriate. 


\section{RPP-11413 Rev. 1}

\section{Roughing Prefilter}

The frames of $\mathrm{N} 1$ filters may be extended $2^{\text {" in }}$ depth to accomodate a roughing prefilter. Indicate the 'P' prefix in the model number to specily this option. Also requires a special size designator. Contact the factory for details. NOTE: Prefitter must be shipped loose on UL-586 listed units.

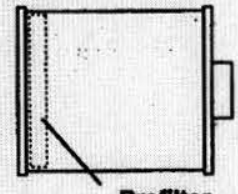

Prefilter or

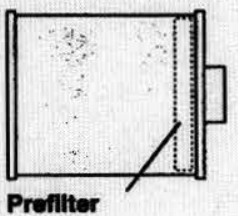

\section{Gasket Seal (N1 Filters Only)}

Gaskets are made from $1 / 4^{n} \times 3 / 4^{n}$ closed cell neoprene material. Specily location of the gasket as upstream or downstream, in the fitter model number.

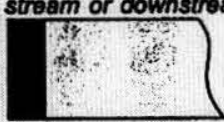

Wood Frame

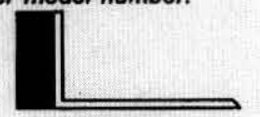

Metal Frame

\section{Drilled Flanges}

Standard flanges may be located on the filter face or on the nipple connection. These flanges may be drilled in a standard pattern or according to customer specifications. Flanders' standard patterns are as follows: $5 / 16^{\text {" diameter }}$ holes equally spaced and centered on the filter face flange; or $5 / 16^{*}$ diameter holes equally spaced and centered on the nipple-connected flange.

Nipple-Connected Flange
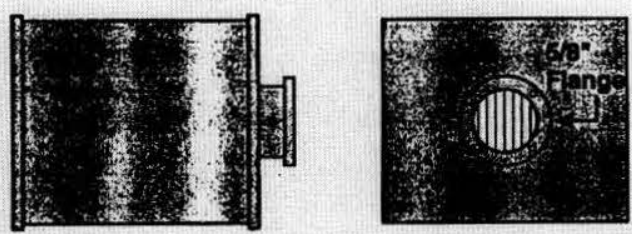

Fitter Face Flange

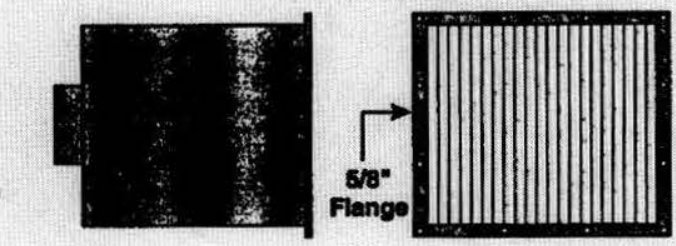

\section{Slip-On Flanges}

Optional 150 pound slip-on flanges for pipe-nippleconnections shall be avallable in carbon steel or Type 304 stainless steel, and in any standard IPS size.

Other sizes and types of flanges are avallable per customer specifications.

\section{Faceguards}

(N1 and N2 Filters)

Standardfaceguard material is $4 \times 4$ mesh, 23-gauge, welded and galvanized dipped steel. Type 304 stainless steel faceguards ( $4 \times 4$ mesh, 18gauge woven wire or 22 gauge welded wire) are also available for highly corrosive atmospheres. Specify faceguard location as upstream, downstream, or both.

\section{UL 586 (N1 and N2 Filters)}

To be listed under UL586, filters must be submitted to Underwriters Laboratories for extensive testing including spot flame and exposure to heated air. A UL586 listing is accepted by the DOE as meeting the Heated Air Requirement as listed in ASME AG-1. UL labels are optional and are applied only if specified by the buyer.

NOTE: High-tomperature sealants are not ellgible for UL58s.

\section{Model Numbers and Speciflcation}

To write a specification for NippleConnected Fliters, use the Designating Chart on Page 16 to determine the model number. Fill in the numbered locations in the Suggested Specification Text on Page 17 with the model number and other appropriate selectlons from the listing at the bottom of the page. 


\section{Roughing Prefilter}

The frames of N1 filters may be extended 2" in depth to accomodate a roughing prefilter, Indicate the 'P' prefix in the model number to specily this option. Also requires a special size designator. Contact the factory for details. NOTE: Prefilter must be shipped loose on UL-586 listed units.

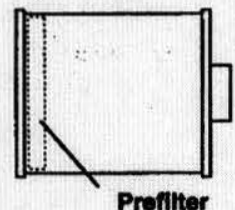

or

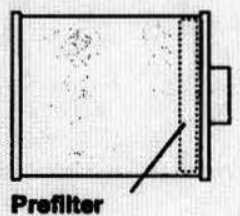

\section{Gasket Seal (N1 Filters Only)}

Gaskets are made from $1 / 4^{n} \times 3 / 4^{n}$ closed cell neoprene material. Specify location of the gasket as upstream or downstream, in the filter model number.

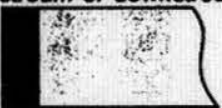

Wood Frame
Metal Frame

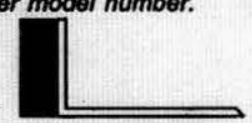

\section{Drilled Flanges}

Standard flanges may be located on the filter face or on the nipple connection. These flanges may be drilled in a standard pattern or according to customer specifications. Flanders' standard pattems are as follows: $5 / 16^{\text {" diameter }}$ holes equally spaced and centered on the filter face flange; or $5 / 16^{n}$ diameter holes equally spaced and centered on the nipple-connectedilange.

Nipple-Connected Flange
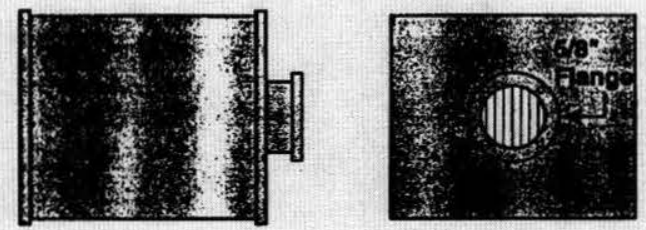

\section{Fiter Face Flange}

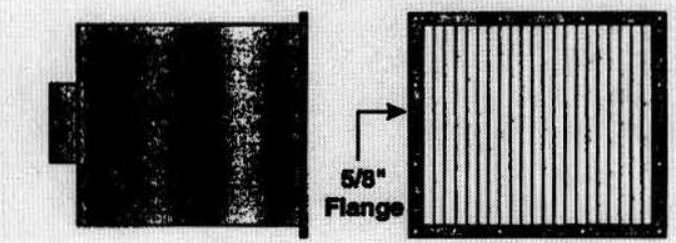

\section{Slip-On Flanges}

Optional 150 pound slip-on flanges for pipe-nipple connections shall be available in carbon steel or Type 304 stainiess steel, and in any standard IPS size.

Other sizes and types of flanges are available per customer specifications.

\section{Faceguards} (N1 and N2 Filters) Standardfaceguard material is $4 \times 4$ mesh, 23-gauge, welded and galvanized dipped

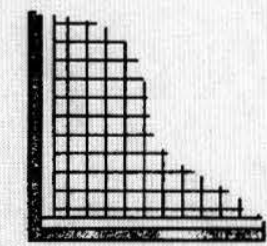
steel. Type 304 stainless steel faceguards ( $4 \times 4$ mesh, 18gauge woven wire or 22 gauge welded wire) are also available for highly corrosive atmospheres. Specily faceguand location as upstream, downstream, or both.

\section{UL 586 (N1 and N2 Filters)}

To be listed under UL586, filters must be submitted to Underwriters Laboratories for extensive testing including spot flame and exposure to heated air. A UL586 listing is accepted by the DOE as meeting the Heated Air Requirement as listed in ASME AG-1. UL labels are optional and are epplied only if specified by the buyer.

NOTE: High-temperature soalants are not ellgible for UL688.

\section{Model Numbers and Specification}

To write a specification for NippleConnected Filters, use the Designating Chart on Page 16 to determine the model number. Fill in the numbered locations in the Suggested Specification Text on Page 17 with the model number and other appropriate selectlons from the llsting at the bottom of the page. 


\section{Model Number Designating Chart}

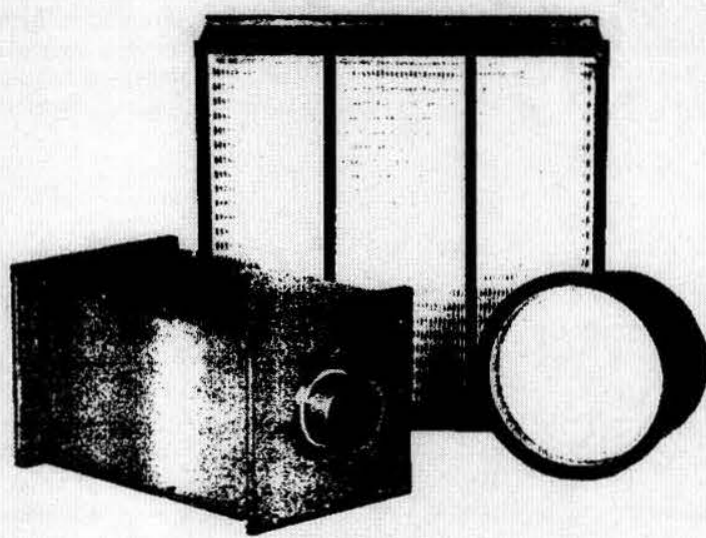

To Order:

Specify the desired filter, refer to the model number charts in this bulletin and/or to the Model Number Designating Codes on the facing page.

Separately write out any required options or any specification not otherwise indicated by the filter model number.

\section{Nuclear Filter Size Designators}

Standard Size Filters are designated using the following Alpha Code for the Height, Width and Depth of the Filter:

Height and Width Designator Depth Designator

The Filter Model Number

$B=8$

$U=113 / 8^{n}$

$\mathrm{C}=12^{\prime \prime}$

$Y=233 / 8^{n}$

$A=31 / 16^{*}$

$E=18^{\prime \prime}$

$\mathrm{G}=24^{*}$

Fitters are coded within the filter model number, which

$\mathrm{N}=30^{\prime \prime}$

$D=57 / 8^{*}$

D2 $=77 / 8^{*}$

$\mathrm{F}=11$ 1/2"

$F 2=131 / 2^{*}$

Hardware - Items such as clips, handies, and plates.

Filter Media - Efficiency of the filter media.

Pack Type - PUREFORMßor separator-type.

Frame Material - Metal or wood.

Frame Style - Fluid or gasket seal designs.

Sealant - Material used to seal the pack to the frame.

Gasket Type/Location

Faceguard Type/Location

Filter Size Code

UL Code - For filters requiring UL labels. (For standard size filters only.) For odd size or filters requiring a " $Z$ " drawing, the UL Code must be specified separate from the filterModelNumber.

Example: T-007-W-42-05-NU-51-13-GG-FU5
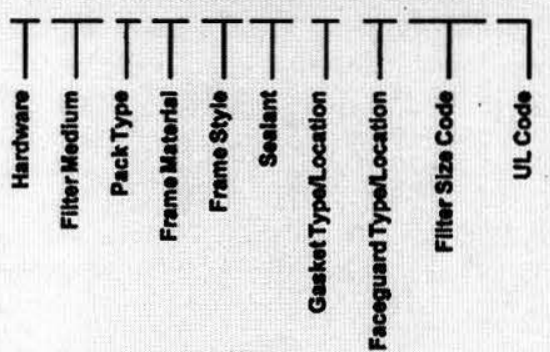

Example: GG-F=24" $\mathrm{H} \times 24^{n} \mathrm{~W} \times 111 / 2^{n} \mathrm{D}$

Odd size designator is an Alpha Numeric Description. The first two numbers specify the Height Whole Number with an Alpha Designator specifying the Height Fraction. The second two numbers specify the Width Whole Number with an Alpha Designator specifying the Width Fraction, and the last Alpha Designator specifies the depth.

Odd Size Designator

Height and Width Alpha Fraction Depth Designator

$A=0^{*} \quad J=1 / 2^{*} \quad A=31 / 16^{*}$

$B=1 / 16^{n} \quad K=9 / 16^{n} \quad D=57 / 8^{n}$

$C=1 / 8^{\prime \prime} \quad L=5 / 8^{*} \quad D 2=77 / 8^{\prime \prime}$

$D=3 / 16^{*} \quad M=11 / 16^{*} \quad F=111 / 2^{*}$

$E=1 / 4^{*} \quad N=3 / 4^{*} \quad F 2=131 / 2^{*}$

$F=5 / 16^{n} \quad P=13 / 16^{*}$

$\mathrm{G}=3 / 8^{\prime \prime} \quad \mathrm{Q}=7 / 8^{\prime \prime}$

$H=7 / 16^{n} \quad R=15 / 16^{*}$

Example: $23 G 23 G F=233 / 8^{\prime \prime} H \times 233 / 8^{\prime \prime} \mathrm{W} \times 11$ 1/2" D

A Z-Drawing will be developed and become the size designator for any filter which has special materials or testing which are not covered in the Style Code System. Example: Z97001 
RPP-11413 Rev. 1

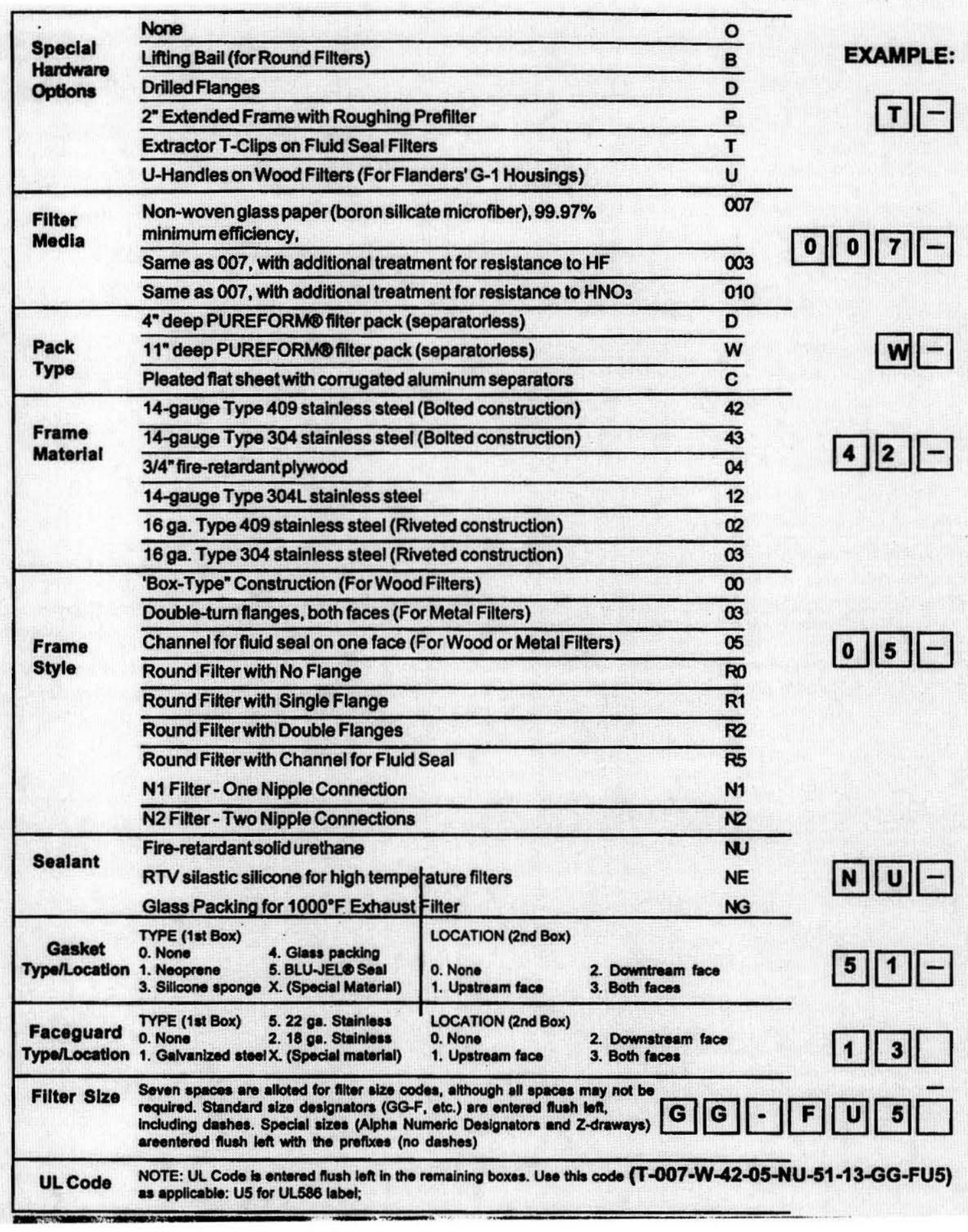




\section{Suggested Speciffcation}

The filters shall be model (1) Nuclear Grade as manufactured by Flanders Filters, Inc., Washington, NC. The filter medium shall be all glass with a wet strength, water-repellent binder in accordance with MIL-F-51079 (latest issue) or ASME AG-1 Section FC, Article l-3000.

\section{To Specify PUREFORM Filter Element:}

Each filter element shall be constructed without the use of spacers of any kind, including separators, tape, string or strips of medium, by pleating a continuous sheet of a formed, corrugated medium back and forth upon itself so that it is self-supporting.

TO Specify SEPARATOR-Type Filter Element: Each filter element shall be constructed by pleating a continuous flat sheet of medium over corrugated .0015" minimum thick aluminum spacers whose edges have been hemmed to resist tearing the medium at the fold.

The element shall be permanently bonded to a (2) integral frame with a fire-retardant urethane sealant. The perimeter of the fitter face shall have (3) to seal it to its mounting device in service. Construction of the filter shall be in a accordance with the essential construction requirements of ASMEAG-1 (latest issue).

Each filter shall be tested, while encapsulated, for resistance to airflow and penetration in accordance with ASME AG-1 Section FC 5200 at the nominal rated capacity listed in table FC- $4000-1$ and at $20 \%$ of that capacity for penetration only (filters with rated capacity of $75 \mathrm{CFM}$ or higher). The penetration at both flows shall not exceed $0.03 \%$.

The HEPA filters shall comply with the performance requirements as listed in ASME AG-1 Section FC. Each filter and filter carton shall bear identical labels indicating the filter model number, the serial number and the resistance and penetration readings at both test flows taken for the filter on the manufacturer's Q107 penetrometer or HFATS System. In addition, the manufacturer shall provide a filter test report and a Certification of Compliance report. The manufacturer shall upon request submit evidence that its filters have been qualified in accordance with ASME AG-1.

Filters that are $24^{\prime \prime} \times 12^{\prime \prime} \times 6^{\prime \prime}$ and larger shall be packaged one fitter per carton. Each filter shall be encased in a flanged, tight-fitting linerboard sleeve that fits within the carton, leaving a dead-air space on four sides of the filter. The top and the bottom of the filter shall be protected with a folded linerboard cushion. Linerboard cartons shall be strapped to a Flanders Type II pallet with H/8" plywood facing on both faces.

\section{Model Numbers and Specification}

Fill in the numbered locations on the Suggested Specification Text by selecting from the corresponding category below:

(1) Filter model number (See Page 16)

(2) Frame material 14-gauge, Type 409 stainless steel (bolted) 14-gauge, Type 304 stainless steol (bolted) 16-gauge, Type 409 stainless steel (riveted) 16-gauge, Type 304 stainless steel (riveted) $3 / 4^{\text {" }}$ thick fire-retardant plywood ...

(3) Frame style No flanges. Two double turn flanges... A 3/4" channel with fluid sealant... A single pipe-nipple connection... Two pipe-nipple connections... 


\section{Environmental Conditions}

\section{Heat Resistance}

In high-temperature applications, the filter media will exhibit a significant loss of strength after the binder burns off. (This normally occurs in the $300^{\circ}-325^{\circ} \mathrm{F}$ range.) The filter media becomes significantly weaker when the binder burns off and Flanders recommends only separator style filters be used in high temperature applications.

Filters not specifically designed for high-temperature applications are nevertheless constructed from selfextinguishing or incombustible components and will withstand periodic temperatures up to $250^{\circ} \mathrm{F}$ with no noticeable change in pressure drop or penetration. However, extended service under such conditions can cause accelerated aging of organic materials and may subsequently contribute to filter failure.

\section{Packaging and Palletizing}

The successful delivery of undamaged HEPA filters depends largely upon good packaging. Shipping damage is minimized by encasing each filter in a tightfitting linerboard sleeve that is flanged outward at its top and bottom and then inserting the sleeved filter into a linerboard carton having a folded linerboard cushion in the top and bottom. This results in a dead-air space around the filter to absorb impact. Flanders packages all filters $24^{\prime \prime} \times 12^{n} \times 5^{7} / \mathrm{s}^{n}$ and larger in this manner. All filter carton material (including the exterior carton, linerboard sleeve, and linerboard cushion) is tested for strength and certified to meet all construction requirements of the applicable freight classification. Additionally, all Nuclear Grade filters are palletized for shipment in groups of cartoned filters stacked side-by-side, with $3 /$ $8^{n}$ plywood facing at the two most vulnerable ends and the aggregate strapped to the pallet.

\section{Humidity and Water Resistance}

HEPA filter media will tolerate high humidity and some direct wetting, but excessive amounts of moisture, either from airbome droplets or condensation, can plug the filter and result in fallure by over-pressure.

Wood frames are unsuitable for high-moisture conditions. since wood expands or warps when wet, and supports biological growth under humid conditions. Metal frame filters are more suitable for moisture laden atmospheres. Because aluminum separators can corrode in some environments and slough particles downstream of the filter, separatorless PUREFORM ${ }^{\text {TM }}$ filters are also recommended for moist conditions, except in hightemperature or caustic applications.

\section{Chemical Resistance}

All materials utilized have good resistance to most organic solvents and are resistant to many weak organic and inorganic alkalies and acids. Exposure to acids such as HF, and those with NOx radicals occurs in nuclear systems fairly often and with varying degrees of impact (HF attacks glass). Information about the potential effects of humidity, various chemical agents, and heated air, and the interrelationship of the construction materials. must be determined by the user through testing.

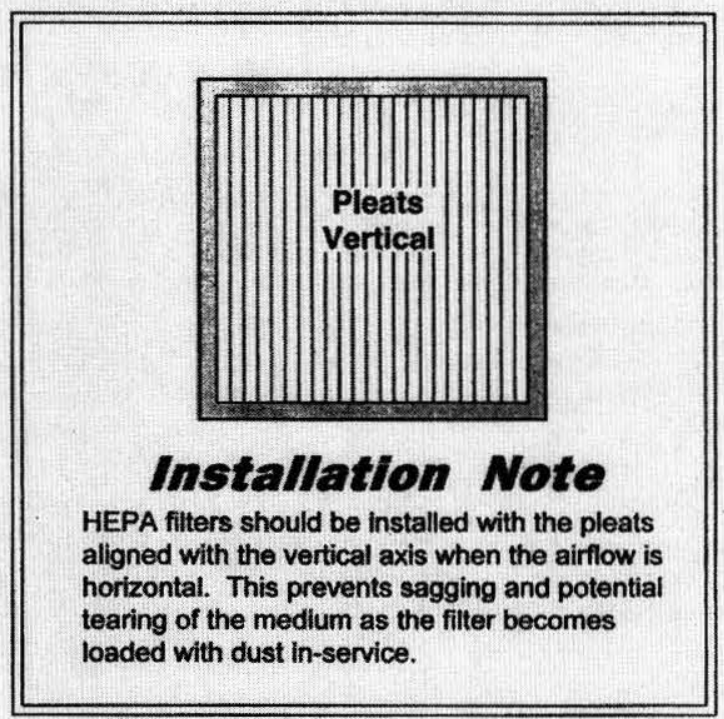




\section{Receipt and Storage Requirements}

HEPA filters should be stored in their original cartons, in an environmentally controlled room. HEPA filters should be oriented vertically with their pleats vertical, and be stacked no more than three cartons (slightly over $6 \mathrm{ft}$.) high unless intermediate bracing or flooring is provided to prevent the weight of the upper tier from bearing on the lower tier. Unless there is obvious damage to the cartons, HEPA filters should not be opened prior to use, or removed from shipping pallets or skids until immediately ready for installation.

While in storage, items should be checked periodically to ensure that they are not exposed to detrimental conditions. Storage areas should be uncluttered and permit easy access to items without the necessity of moving other items to get to them. A item-control procedure is suggested for the storage area to ensure that items are not removed from the area without proper authority, and to prevent improper or rejected items from being installed in the system. Materials and components should be moved a minimum number of times (receipt inspection, storage and release for installation only) and handled in a manner that does not damage the item or its packaging. If wrappings or cartons are removed for receiving inspection, they should be replaced and positively sealed immediately upon completion of the inspection. Receiving and storage personnel shall be informed of the necessity of proper handling of all components, especially the HEPA filters.

\section{Shelf Life Information}

Flanders recommends the filter be stored in its original shipping carton to prevent it from being exposed to ultra violet rays and possible damage to the filter media. The filter should be stored in a controlled area, $0^{\circ}-120^{\circ} \mathrm{F}$, and should not be exposed to ozone depleting sources. If these parameters are satisfied and storage requirements as detailed are maintained, the filter shelf life should be three (3) years from gasket cure date or three (3) years from manufacturing date for fluid seal filters. 
RPP-11413 Rev. 1

\section{APPENDIX H}

FLANDERS FILTERS, INC. LETTERS RELATED TO

HEPA FILTER TEMPERATURE LIMITS BASED ON HEPA FILTER MATERIALS 
RPP-11413 Rev. 1

This page intentionally left blank. 


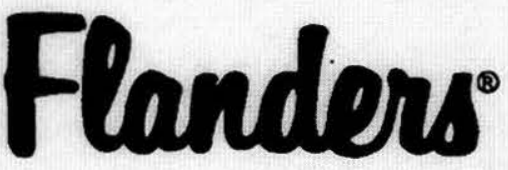

Foremost in Air Filtration
Flanders Filters, Inc. 531 Flanders Filters Rd. Washington, NC 27889

Tel: 2529468081

Fax: 2529463425

COGEMA Engineering Corp.

2425 Stevens Drive

Richland, WA 99352

Attn: Mr. Eric Berglin

Date: July 26, 2002

\section{Dear Eric,}

Please find below the requested information on temperature limitations of filter components.

I have reviewed our supplier maximum operating temperatures information on the filter components you identified for the as follows.

1. Fire Retardant Solid Polyurethane - Current manufacture in a documented letter to Flanders states maximum peak temperature of $250^{\circ} \mathrm{F}$.

2. RTV Silastic Silicone-Current manufacture in their published literature states for general purpose paste maximum continuous operating temperature of $400^{\circ} \mathrm{F}$ and for high temperature paste maximum continuos operating temperature of $500^{\circ} \mathrm{F}$.

3. Neoprene Gasket - Current manufacture in their published literature states Temperature Use High $200^{\circ} \mathrm{F}$.

4. Silicone Sponge Gasket - Current manufacture in their published literature states prolonged exposure to temperature $+500^{\circ} \mathrm{F}$.

5. Glass Packing - No manufacture information available however the cement that is used to seal the glass packing has manufacture published information as maximum service temperature of $1750^{\circ} \mathrm{F}$. 


\section{RPP-11413 Rev. 1}

6. Blu-Jel - Current manufacture published literature states useful temperature as $400^{\circ} \mathrm{F}$.

We hope this information is helpful to you. If you have any questions, please feel free to contact me.

Sincerely,

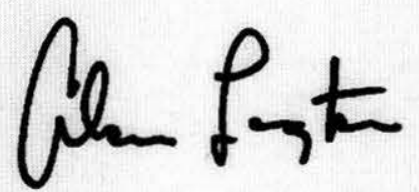

Alan Longton

V.P. Foremarket Sales and Eng. 
RPP-11413 Rev. 1

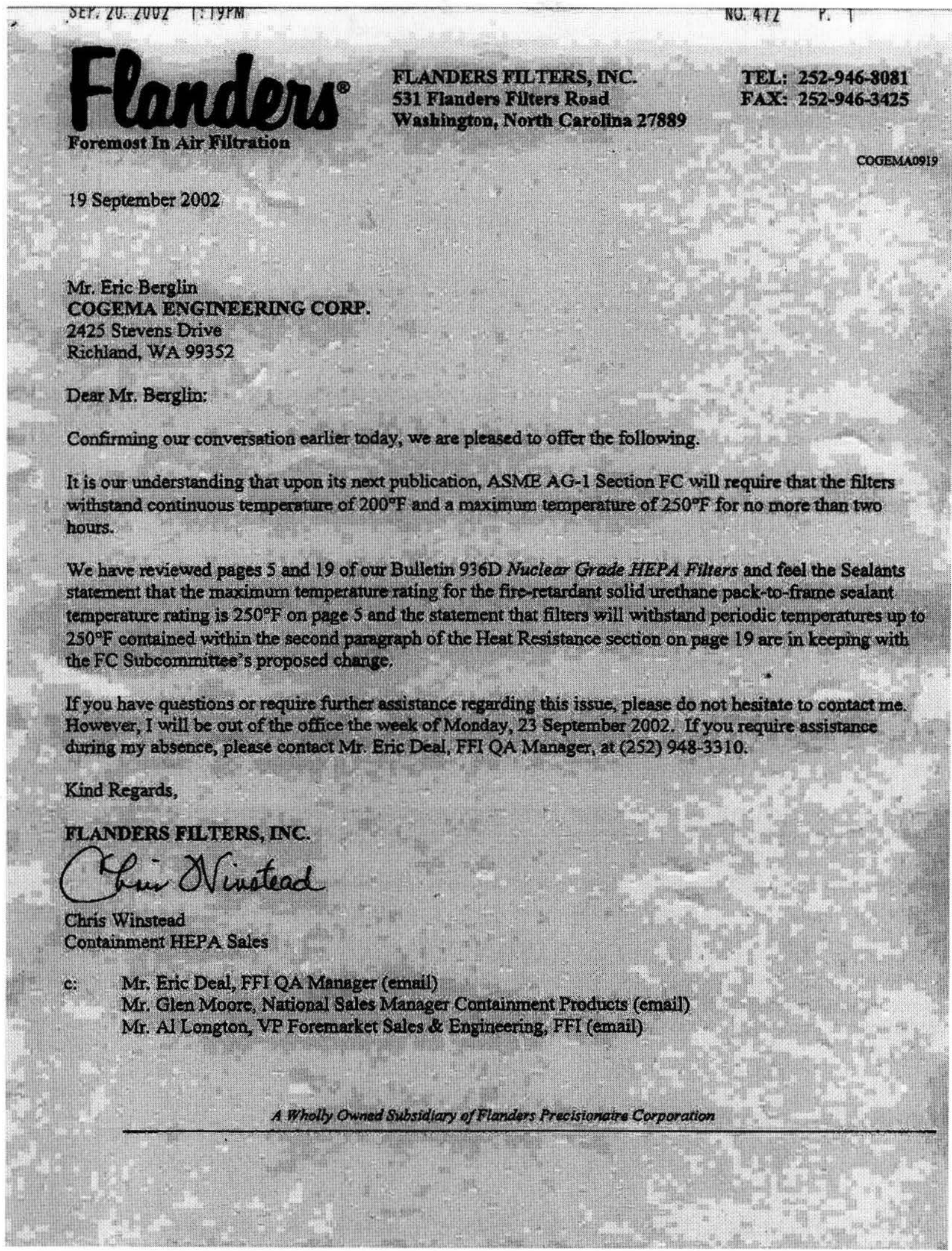


RPP-11413 Rev. 1

This page intentionally left blank. 
RPP-11413 Rev. 1

\section{APPENDIX I}

\section{MAXIMUM TEMPERATURES FROM TMACS FOR TANK FARM TANKS} (May 16, 2002) 
RPP-11413 Rev. 1

This page intentionally left blank. 
Figure I-1. Maximum Temperature By Tank

( $\left.{ }^{\circ} \mathrm{F}\right)$

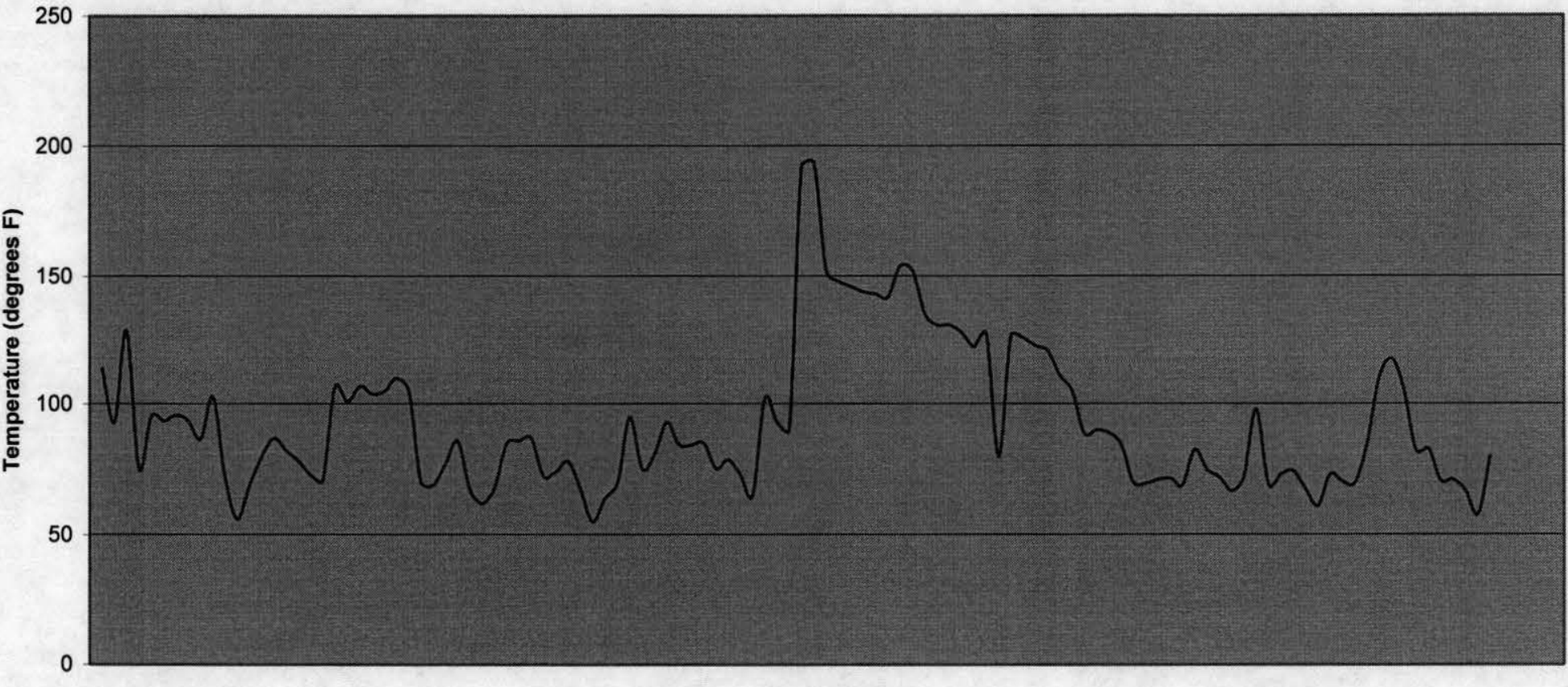

Tank Number 
Table I-1. Maximum Temperature, Highest TC Location - Data. (5 Sheets)

\begin{tabular}{|c|c|c|c|c|c|c|c|c|c|c|}
\hline Tank & $\mid \begin{array}{c}\text { Temperature } \\
\left({ }^{\circ} \mathbf{F}\right)\end{array}$ & $\begin{array}{l}\text { Reading } \\
\text { Date }\end{array}$ & Riser \# & TC\# & $\begin{array}{c}\text { Maximum } \\
\text { TC Height In Tank } \\
\text { (inches from tank } \\
\text { bottom) }\end{array}$ & $\begin{array}{l}\text { Maximum Waste } \\
\text { Surface Level } \\
\text { (inches from tank } \\
\text { bottom) }\end{array}$ & $\begin{array}{c}\text { TC Height Above } \\
\text { Waste Surface } \\
\text { (inches) }\end{array}$ & $\begin{array}{c}\text { First } \\
\text { Temperature } \\
\text { Reading Date }\end{array}$ & \begin{tabular}{|c|} 
Latest \\
Temperature \\
Reading Date
\end{tabular} & $\begin{array}{c}\text { Years of } \\
\text { Data }\end{array}$ \\
\hline A-101 & 113.9 & $03 / 06 / 02$ & Riser 12 & 18 & 459.96 & 360.5 & 99.46 & $7 / 1 / 81$ & $5 / 16 / 02$ & 20.88 \\
\hline A-102 & 93 & $10 / 01 / 90$ & Riser 7 & 18 & 460 & 34.4 & 425.6 & $7 / 1 / 81$ & $6 / 21 / 95$ & 13.97 \\
\hline A-106 & 129 & $07 / 14 / 77$ & Riser 14 & 18 & 466.68 & 46.5 & 420.18 & $7 / 1 / 77$ & $12 / 29 / 01$ & 24.49 \\
\hline AN-101 & 75.38 & $09 / 27 / 95$ & Riser 4A & 18 & 459.96 & 394.25 & 65.71 & $8 / 25 / 94$ & $5 / 16 / 02$ & 7.73 \\
\hline AN-102 & 95.54 & $08 / 05 / 95$ & Riser 4A & 18 & 459.96 & 411.8 & 48.16 & $8 / 25 / 94$ & $5 / 16 / 02$ & 7.73 \\
\hline AN-103 & 93.56 & $09 / 17 / 97$ & Riser 15A & 22 & 427 & 406.5 & 20.5 & $9 / 16 / 97$ & $5 / 16 / 02$ & 4.67 \\
\hline AN-104 & 95.72 & $09 / 25 / 97$ & Riser $15 \mathrm{~A}$ & 22 & 427 & 409.65 & 17.35 & $9 / 16 / 97$ & $5 / 16 / 02$ & 4.67 \\
\hline AN-105 & 93.56 & $09 / 20 / 97$ & Riser 15A & 22 & 427 & 415.5 & 11.5 & $9 / 16 / 97$ & $5 / 16 / 02$ & 4.67 \\
\hline AN-106 & 86.54 & $09 / 14 / 94$ & Riser 4A & 18 & 459.96 & 385.6 & 74.36 & $8 / 25 / 94$ & $5 / 16 / 02$ & 7.73 \\
\hline AN-107 & 102.74 & $09 / 25 / 95$ & Riser 4A & 18 & 459.96 & 410.7 & 49.26 & $8 / 25 / 94$ & $5 / 16 / 02$ & 7.73 \\
\hline AP-102 & 72 & $02 / 08 / 93$ & Historical & 18 & 460 & 404.75 & 55.25 & $7 / 10 / 89$ & $2 / 22 / 93$ & 3.62 \\
\hline AP-103 & 56 & $02 / 01 / 93$ & Historical & 18 & 460 & 413.5 & 46.5 & $1 / 25 / 93$ & $2 / 22 / 93$ & 0.08 \\
\hline AP-104 & 69 & $10 / 01 / 90$ & Historical & 18 & 460 & 409.25 & 50.75 & $7 / 10 / 89$ & $2 / 22 / 93$ & 3.62 \\
\hline AP-105 & 80 & $09 / 26 / 89$ & Historical & 18 & 460 & 414.25 & 45.75 & $7 / 10 / 89$ & $9 / 21 / 92$ & 3.20 \\
\hline AW-101 & 86.9 & $09 / 05 / 98$ & Riser 17 & 22 & 427 & 419.5 & 7.5 & $6 / 30 / 98$ & $5 / 16 / 02$ & 3.88 \\
\hline AW-102 & 82.2 & $08 / 07 / 99$ & Riser 6 & 18 & 459.96 & 397.25 & 62.71 & $7 / 22 / 98$ & $5 / 16 / 02$ & 3.82 \\
\hline AW-103 & 78 & $04 / 03 / 01$ & Riser 6 & 18 & 459.96 & 412.9 & 47.06 & $7 / 22 / 98$ & $5 / 16 / 02$ & 3.82 \\
\hline AW-104 & 72.6 & $09 / 25 / 98$ & Riser 6 & 18 & 459.96 & 410 & 49.96 & $7 / 22 / 98$ & $5 / 16 / 02$ & 3.82 \\
\hline AW-105 & 70.8 & $09 / 17 / 98$ & Riser 6 & 18 & 459.96 & 398.75 & 61.21 & $7 / 22 / 98$ & $5 / 16 / 02$ & 3.82 \\
\hline AW-106 & 106.7 & $05 / 01 / 00$ & Riser 6 & 18 & 459.96 & 403.4 & 56.56 & $7 / 22 / 98$ & $5 / 16 / 02$ & 3.82 \\
\hline AX-101 & 101 & $10 / 10 / 86$ & Riser 9B & 18 & 462 & 280.85 & 181.15 & $7 / 1 / 81$ & $5 / 18 / 98$ & 16.88 \\
\hline AX-102 & 107 & $08 / 25 / 77$ & Riser 9C & 18 & 469.08 & 20.5 & 448.58 & $8 / 21 / 77$ & $9 / 1 / 97$ & 20.03 \\
\hline AX-103 & 104 & $11 / 08 / 88$ & Riser 09B & 6 & 365.04 & 44.4 & 320.64 & $4 / 1 / 82$ & $5 / 16 / 02$ & 20.13 \\
\hline AX-104 & 105 & $07 / 07 / 86$ & Riser 9C & 18 & 468.84 & 4.5 & 464.34 & $7 / 1 / 81$ & $12 / 29 / 01$ & 20.49 \\
\hline AY-102 & 110 & $10 / 30 / 01$ & Riser 029 & 22 & 430 & 362.75 & 67.25 & $9 / 14 / 98$ & $5 / 16 / 02$ & 3.67 \\
\hline B-101 & 105 & $09 / 01 / 86$ & Riser 9 & 14 & 316 & 46.96 & 269.04 & $8 / 14 / 74$ & $9 / 1 / 86$ & 12.05 \\
\hline B-104 & 70 & $07 / 31 / 75$ & Riser 5 & 12 & 288 & 147.25 & 140.75 & $7 / 31 / 75$ & $1 / 9 / 79$ & 3.44 \\
\hline
\end{tabular}


Table I-1. Maximum Temperature, Highest TC Location - Data. (5 Sheets)

\begin{tabular}{|c|c|c|c|c|c|c|c|c|c|c|}
\hline Tank & $\begin{array}{c}\text { Temperature } \\
\left({ }^{\circ} \mathrm{F}\right)\end{array}$ & $\begin{array}{l}\text { Reading } \\
\text { Date }\end{array}$ & Riser \# & TC\# & $\begin{array}{l}\text { Maximum } \\
\text { TC Height in Tank } \\
\text { (inches from tank } \\
\text { bottom) }\end{array}$ & $\begin{array}{l}\text { Maximum Waste } \\
\text { Surface Level } \\
\text { (inches from tank } \\
\text { bottom) }\end{array}$ & $\begin{array}{c}\text { TC Height Above } \\
\text { Waste Surface } \\
\text { (inches) }\end{array}$ & $\begin{array}{c}\text { First } \\
\text { Temperature } \\
\text { Reading Date }\end{array}$ & $\begin{array}{c}\text { Latest } \\
\text { Temperature } \\
\text { Reading Date }\end{array}$ & $\begin{array}{c}\text { Years of } \\
\text { Data }\end{array}$ \\
\hline B-107 & 69 & $07 / 16 / 78$ & Riser 3 & 12 & 288 & 66.49 & 221.51 & $5 / 19 / 78$ & $11 / 12 / 91$ & 13.48 \\
\hline B-110 & 77 & $01 / 09 / 79$ & Riser 8 & 12 & 288 & 96.74 & 191.26 & $5 / 14 / 75$ & $1 / 9 / 79$ & 3.65 \\
\hline B-111 & 85.7 & $07 / 01 / 93$ & Riser 8 & 12 & 288 & 95.32 & 192.68 & $5 / 7 / 75$ & $7 / 26 / 00$ & 25.22 \\
\hline B-201 & 67 & $07 / 16 / 77$ & Riser 1 & 12 & 288 & 157.74 & 130.26 & $7 / 31 / 75$ & $2 / 26 / 02$ & 26.57 \\
\hline B-203 & 62 & $02 / 05 / 90$ & Riser 1 & 12 & 288 & 265.44 & 22.56 & $4 / 1 / 76$ & $1 / 5 / 00$ & 23.76 \\
\hline B-204 & 68 & $07 / 16 / 78$ & Riser 1 & 12 & 288 & 261.7 & 26.3 & $7 / 16 / 78$ & $1 / 9 / 96$ & 17.48 \\
\hline BX-101 & 85 & $08 / 26 / 75$ & Riser 2 & 12 & 278 & 24.9 & 253.1 & $9 / 18 / 74$ & $6 / 12 / 93$ & 18.73 \\
\hline BX-103 & 86 & $01 / 16 / 78$ & Riser 1 & 11 & 264 & 34.06 & 229.94 & $9 / 18 / 74$ & $5 / 16 / 02$ & 27.66 \\
\hline BX-105 & 87 & $09 / 03 / 84$ & Riser 7 & 14 & 374 & 32.74 & 341.26 & $6 / 11 / 80$ & $9 / 7 / 87$ & 7.24 \\
\hline BX-106 & 72.32 & $10 / 14 / 94$ & Riser 1 & 6 & 193 & 20.58 & 172.42 & $4 / 6 / 94$ & $5 / 16 / 02$ & 8.11 \\
\hline BX-107 & 74 & $10 / 26 / 80$ & Riser 4 & 14 & 374 & 133.9 & 240.1 & $7 / 25 / 75$ & $4 / 6 / 82$ & 6.70 \\
\hline BX-108 & 78 & $01 / 10 / 81$ & Riser 5 & 14 & 374 & 18.94 & 355.06 & $1 / 10 / 81$ & $1 / 10 / 81$ & 0.00 \\
\hline BX-109 & 67.6 & $07 / 05 / 00$ & Riser 3 & 12 & 288 & 77.64 & 210.36 & $7 / 5 / 00$ & $7 / 5 / 00$ & 0.00 \\
\hline BX-110 & 55 & $04 / 18 / 94$ & Riser 1 & 14 & 375.6 & 80.01 & 295.59 & $4 / 18 / 94$ & $4 / 18 / 94$ & 0.00 \\
\hline BX-112 & 64 & $07 / 16 / 77$ & Riser 1 & 14 & 374 & 67.4 & 306.6 & $7 / 16 / 77$ & $4 / 7 / 79$ & 1.73 \\
\hline BY-101 & 70 & $04 / 04 / 94$ & Riser 5 & 6 & 179.28 & 168.5 & 10.78 & $4 / 4 / 94$ & $4 / 4 / 94$ & 0.00 \\
\hline BY-102 & 95 & $04 / 27 / 77$ & Historical & 14 & 316 & 167 & 149 & $5 / 20 / 76$ & $4 / 22 / 79$ & 2.92 \\
\hline BY-103 & 75.2 & $09 / 25 / 98$ & Riser 5 & 8 & 378 & 182 & 196 & $4 / 3 / 96$ & $5 / 16 / 02$ & 6.12 \\
\hline BY-107 & 80.78 & $10 / 28 / 98$ & Riser 5 & 8 & 364 & 112 & 252 & $4 / 3 / 96$ & $5 / 16 / 02$ & 6.12 \\
\hline BY-109 & 93 & $08 / 28 / 76$ & Historical & 12 & 268 & 182.4 & 85.6 & $5 / 7 / 76$ & $7 / 16 / 78$ & 2.19 \\
\hline BY-110 & 84.38 & $10 / 14 / 94$ & Riser 10A & 6 & 292 & 191.75 & 100.25 & $3 / 31 / 93$ & $5 / 16 / 02$ & 9.13 \\
\hline BY-110 & 84.2 & $10 / 14 / 94$ & Riser 1 & 6 & 298 & 191.75 & 106.25 & $3 / 17 / 93$ & $5 / 16 / 02$ & 9.16 \\
\hline C-108 & 85 & $12 / 06 / 93$ & Riser 1 & 6 & 128.04 & 36.31 & 91.73 & $11 / 2 / 93$ & $5 / 16 / 02$ & 8.54 \\
\hline C-109 & 75.2 & $03 / 04 / 93$ & Riser 3 & 11 & 244 & 32.41 & 211.59 & $1 / 29 / 93$ & $3 / 8 / 94$ & 1.11 \\
\hline C-111 & 78.62 & $09 / 29 / 98$ & Riser 6 & 6 & 267 & 16.75 & 250.25 & $4 / 3 / 96$ & $5 / 16 / 02$ & 6.12 \\
\hline $\mathrm{C}-112$ & 72.8 & $07 / 16 / 93$ & Riser 1 & 16 & 364 & 45.6 & 318.4 & $4 / 8 / 81$ & $7 / 16 / 93$ & 12.27 \\
\hline C-204 & 65 & $11 / 01 / 76$ & Riser 6 & 11 & 244 & 18.5 & 225.5 & $4 / 22 / 75$ & $5 / 15 / 77$ & 2.06 \\
\hline S-103 & 102 & $10 / 19 / 84$ & Riser 4 & 6 & 292.68 & 106 & 186.68 & $7 / 1 / 81$ & $5 / 16 / 02$ & 20.88 \\
\hline
\end{tabular}


Table I-1. Maximum Temperature, Highest TC Location - Data. (5 Sheets)

\begin{tabular}{|c|c|c|c|c|c|c|c|c|c|c|}
\hline Tank & $\begin{array}{c}\text { Temperature } \\
\left({ }^{\circ} \mathrm{F}\right)\end{array}$ & $\begin{array}{l}\text { Reading } \\
\text { Date }\end{array}$ & Riser \# & TC\# & $\begin{array}{l}\text { Maximum } \\
\text { TC Height In Tank } \\
\text { (inches from tank } \\
\text { bottom) }\end{array}$ & $\begin{array}{l}\text { Maximum Waste } \\
\text { Surface Level } \\
\text { (inches from tank } \\
\text { bottom) }\end{array}$ & $\mid \begin{array}{c}\text { TC Height Above } \\
\text { Waste Surface } \\
\text { (inches) }\end{array}$ & $\begin{array}{c}\text { First } \\
\text { Temperature } \\
\text { Reading Date }\end{array}$ & \begin{tabular}{c|} 
Latest \\
Temperature \\
Reading Date
\end{tabular} & $\begin{array}{c}\text { Years of } \\
\text { Data }\end{array}$ \\
\hline S-104 & 93 & $11 / 13 / 91$ & Riser 4 & 14 & 366 & 115 & 251 & $7 / 3 / 89$ & $1 / 4 / 95$ & 5.50 \\
\hline S-105 & 90 & $09 / 06 / 79$ & Riser 4 & 14 & 366.72 & 164.7 & 202.02 & $6 / 1 / 76$ & $7 / 1 / 95$ & 19.08 \\
\hline SX-101 & 192 & $09 / 01 / 85$ & Riser 15 & 6 & 383.04 & 176.6 & 206.44 & $1 / 9 / 84$ & $5 / 16 / 02$ & 18.35 \\
\hline SX-102 & 194 & $09 / 01 / 85$ & Riser 16 & 6 & 377.4 & 320.8 & 56.6 & $12 / 1 / 81$ & $5 / 16 / 02$ & 20.46 \\
\hline SX-107 & 152 & $01 / 20 / 89$ & Riser 10 & 8 & 62 & 44.75 & 17.25 & $1 / 20 / 89$ & $5 / 16 / 02$ & 13.32 \\
\hline SX-107 & 148 & $01 / 20 / 89$ & Riser 18 & 8 & 172 & 44.75 & 127.25 & $1 / 20 / 89$ & $5 / 3 / 89$ & 0.29 \\
\hline SX-107 & 146 & $01 / 20 / 89$ & Riser 12 & 8 & 172 & 44.75 & 127.25 & $1 / 20 / 89$ & $1 / 20 / 89$ & 0.00 \\
\hline SX-107 & 144 & $01 / 20 / 89$ & Riser 19 & 8 & 172 & 44.75 & 127.25 & $1 / 20 / 89$ & $7 / 20 / 89$ & 0.50 \\
\hline SX-107 & 143 & $01 / 20 / 89$ & Riser 9 & 8 & 172 & 44.75 & 127.25 & $1 / 20 / 89$ & $7 / 20 / 89$ & 0.50 \\
\hline SX-107 & 142 & $01 / 20 / 89$ & Riser 11 & 8 & 172 & 44.75 & 127.25 & $1 / 20 / 89$ & $1 / 20 / 89$ & 0.00 \\
\hline SX-108 & 154 & $10 / 31 / 83$ & Riser 9 & 4 & 56.04 & 47 & 9.04 & $7 / 1 / 81$ & $7 / 20 / 89$ & 8.05 \\
\hline SX-108 & 152 & $10 / 31 / 83$ & Riser 14 & 4 & 56.04 & 47 & 9.04 & $7 / 1 / 81$ & $7 / 20 / 89$ & 8.05 \\
\hline SX-109 & 135 & $12 / 05 / 89$ & Riser 14 & 8 & 172 & 96 & 76 & $12 / 5 / 89$ & $12 / 5 / 89$ & 0.00 \\
\hline SX-109 & 131 & $12 / 05 / 89$ & Riser 18 & 8 & 172 & 96 & 76 & $12 / 5 / 89$ & $12 / 5 / 89$ & 0.00 \\
\hline SX-110 & 131 & $07 / 25 / 92$ & Riser 18 & 7 & 172 & 28.75 & 143.25 & $2 / 5 / 92$ & $7 / 25 / 92$ & 0.47 \\
\hline SX-110 & 128 & $07 / 25 / 92$ & Riser 10 & 8 & 172 & 28.75 & 143.25 & $2 / 5 / 92$ & $7 / 25 / 92$ & 0.47 \\
\hline SX-111 & 122.7 & $07 / 20 / 89$ & Riser 15 & 8 & 172 & 50.13 & 121.87 & $6 / 13 / 89$ & $7 / 20 / 89$ & 0.10 \\
\hline SX-112 & 127.8 & $07 / 20 / 89$ & Riser 18 & 8 & 172 & 38.5 & 133.5 & $6 / 13 / 89$ & $7 / 20 / 89$ & 0.10 \\
\hline SX-113 & 80 & $01 / 06 / 89$ & Riser 3 & 18 & 462 & 16 & 446 & $1 / 6 / 89$ & $7 / 2 / 95$ & 6.49 \\
\hline SX-114 & 127 & $12 / 05 / 89$ & Riser 12 & 8 & 172 & 70.25 & 101.75 & $6 / 13 / 89$ & $12 / 5 / 89$ & 0.48 \\
\hline SX-114 & 126 & $12 / 05 / 89$ & Riser 14 & 8 & 172 & 70.25 & 101.75 & $12 / 5 / 89$ & $12 / 5 / 89$ & 0.00 \\
\hline SX-114 & 123 & $12 / 05 / 89$ & Riser 11 & 8 & 172 & 70.25 & 101.75 & $12 / 5 / 89$ & $12 / 5 / 89$ & 0.00 \\
\hline SX-114 & 121 & $12 / 05 / 89$ & Riser 18 & 8 & 172 & 70.25 & 101.75 & $12 / 5 / 89$ & $12 / 5 / 89$ & 0.00 \\
\hline SX-114 & 111 & $12 / 05 / 89$ & Riser 15 & 8 & 172 & 70.25 & 101.75 & $12 / 5 / 89$ & $12 / 5 / 89$ & 0.00 \\
\hline SY-102 & 104.9 & $10 / 25 / 00$ & Riser 4A & 18 & 460 & 406.75 & 53.25 & $11 / 8 / 94$ & $5 / 16 / 02$ & 7.52 \\
\hline SY-103 & 88.7 & $09 / 25 / 95$ & Riser 4A & 18 & 460 & 286.25 & 173.75 & $11 / 11 / 94$ & $5 / 16 / 02$ & 7.51 \\
\hline $\mathrm{T}-105$ & 90 & $09 / 03 / 78$ & Riser 4 & 12 & 288 & 41.56 & 246.44 & $9 / 2 / 76$ & $9 / 8 / 79$ & 3.02 \\
\hline $\mathrm{T}-109$ & 89 & $09 / 03 / 78$ & Riser 8 & 11 & 302 & 30.2 & 271.8 & $2 / 11 / 76$ & $8 / 27 / 98$ & 22.54 \\
\hline
\end{tabular}


Table I-1. Maximum Temperature, Highest TC Location - Data. (5 Sheets)

\begin{tabular}{|c|c|c|c|c|c|c|c|c|c|c|}
\hline Tank & $\begin{array}{c}\text { Temperature } \\
\left(^{\circ} \mathrm{F}\right)\end{array}$ & $\begin{array}{l}\text { Reading } \\
\text { Date }\end{array}$ & Riser \# & TC\# & $\begin{array}{c}\text { Maximum } \\
\text { TC Height In Tank } \\
\text { (inches from tank } \\
\text { bottom) }\end{array}$ & $\begin{array}{c}\text { Maximum Waste } \\
\text { Surface Level } \\
\text { (inches from tank } \\
\text { bottom) }\end{array}$ & $\begin{array}{c}\text { TC Height Above } \\
\text { Waste Surface } \\
\text { (inches) }\end{array}$ & $\begin{array}{c}\text { First } \\
\text { Temperature } \\
\text { Reading Date }\end{array}$ & $\begin{array}{c}\text { Latest } \\
\text { Temperature } \\
\text { Reading Date }\end{array}$ & $\begin{array}{c}\text { Years of } \\
\text { Data }\end{array}$ \\
\hline TX-102 & 84.2 & $11 / 10 / 81$ & Historical & 12 & 268 & 130.25 & 137.75 & $5 / 19 / 77$ & $2 / 22 / 93$ & 15.76 \\
\hline TX-103 & 69.7 & $01 / 13 / 95$ & Riser 4 & 14 & 373.44 & 82.4 & 291.04 & $7 / 3 / 94$ & $1 / 3 / 96$ & 1.50 \\
\hline TX-104 & 69.6 & $01 / 03 / 96$ & Riser 4 & 14 & 371.76 & 38.77 & 332.99 & $3 / 2 / 93$ & $1 / 3 / 96$ & 2.84 \\
\hline TX-106 & 71.1 & $01 / 03 / 96$ & Riser 4 & 14 & 378.72 & 168 & 210.72 & $7 / 7 / 94$ & $1 / 3 / 96$ & 1.49 \\
\hline TX-107 & 71.5 & $01 / 13 / 95$ & Riser 4 & 14 & 372.12 & 23.6 & 348.52 & $7 / 3 / 94$ & $1 / 3 / 96$ & 1.50 \\
\hline TX-108 & 68.9 & $01 / 13 / 95$ & Riser 4 & 14 & 372.24 & 57.26 & 314.98 & $7 / 3 / 94$ & $1 / 3 / 96$ & 1.50 \\
\hline TX-109 & 82.4 & $01 / 13 / 95$ & Riser 8 & 14 & 372.12 & 169.4 & 202.72 & $7 / 3 / 94$ & $1 / 3 / 96$ & 1.50 \\
\hline TX-110 & 74.7 & $04 / 23 / 91$ & Historical & 12 & 268 & 191.5 & 76.5 & $4 / 23 / 91$ & $2 / 22 / 93$ & 1.83 \\
\hline TX-111 & 72 & $07 / 13 / 93$ & Historical & 14 & 316 & 159.5 & 156.5 & $3 / 2 / 93$ & $1 / 6 / 94$ & 0.84 \\
\hline TX-112 & 66.8 & $01 / 13 / 95$ & Riser 8 & 14 & 369.36 & 255.75 & 113.61 & $7 / 3 / 94$ & $1 / 3 / 96$ & 1.50 \\
\hline TX-113 & 72 & $07 / 03 / 94$ & Riser 8 & 14 & 370 & 235 & 135 & $7 / 3 / 94$ & $1 / 3 / 96$ & 1.50 \\
\hline TX-114 & 98 & $09 / 02 / 77$ & Riser 4 & 12 & 268 & 216.25 & 51.75 & $5 / 19 / 77$ & $11 / 10 / 81$ & 4.48 \\
\hline TX-115 & 69 & $07 / 13 / 93$ & Historical & 14 & 316 & 229.5 & 86.5 & $3 / 2 / 93$ & $1 / 6 / 94$ & 0.84 \\
\hline TX-116 & 73 & $09 / 08 / 77$ & Riser 4 & 12 & 268 & 217.75 & 50.25 & $9 / 8 / 77$ & $9 / 8 / 77$ & 0.00 \\
\hline TX-118 & 74.3 & $10 / 20 / 99$ & Riser 1 & 6 & 194 & 141.9 & 52.1 & $4 / 3 / 96$ & $5 / 16 / 02$ & 6.12 \\
\hline TY-101 & 67.64 & $10 / 27 / 98$ & Riser 3 & 8 & 343 & 52.13 & 290.87 & $12 / 12 / 95$ & $5 / 16 / 02$ & 6.43 \\
\hline TY-102 & 61 & $07 / 03 / 94$ & Riser 4 & 14 & 371.4 & 36.4 & 335 & $7 / 1 / 94$ & $7 / 3 / 94$ & 0.01 \\
\hline TY-105 & 73 & $01 / 01 / 89$ & Riser 3 & 14 & 384 & 94 & 290 & $1 / 1 / 89$ & $7 / 12 / 95$ & 6.53 \\
\hline TY-106 & 70.4 & $09 / 26 / 89$ & Historical & 14 & 316 & 14.25 & 301.75 & $1 / 4 / 88$ & $1 / 1 / 94$ & 5.99 \\
\hline U-101 & 69.5 & $11 / 13 / 91$ & Historical & 11 & 244 & 5.25 & 238.75 & $1 / 1 / 89$ & $1 / 6 / 94$ & 5.01 \\
\hline U-102 & 84 & $07 / 05 / 87$ & Historical & 11 & 244 & 144.98 & 99.02 & $7 / 5 / 87$ & $1 / 17 / 94$ & 6.53 \\
\hline U-103 & 110 & $08 / 05 / 77$ & Riser 1 & 11 & 309.36 & 179.7 & 129.66 & $6 / 10 / 75$ & $5 / 30 / 95$ & 19.97 \\
\hline U-105 & 118 & $08 / 05 / 77$ & Riser 1 & 11 & 309.36 & 165.05 & 144.31 & $6 / 10 / 75$ & $5 / 30 / 95$ & 19.97 \\
\hline U-106 & 106 & $10 / 11 / 76$ & Riser 1 & 11 & 308.16 & 90.46 & 217.7 & $9 / 14 / 75$ & $5 / 8 / 95$ & 19.65 \\
\hline U-110 & 82 & $01 / 01 / 88$ & Historical & 11 & 244 & 75.61 & 168.39 & $7 / 5 / 87$ & $1 / 17 / 94$ & 6.53 \\
\hline U-111 & 83 & $07 / 05 / 87$ & Historical & 11 & 244 & 131.19 & 112.81 & $7 / 5 / 87$ & $3 / 21 / 94$ & 6.71 \\
\hline U-112 & 70.6 & $11 / 13 / 91$ & Historical & 11 & 244 & 13.5 & 230.5 & $1 / 1 / 88$ & $3 / 21 / 94$ & 6.22 \\
\hline U-201 & 71 & $11 / 05 / 92$ & Historical & 11 & 244 & 29.75 & 214.25 & $7 / 5 / 87$ & $11 / 5 / 92$ & 5.33 \\
\hline
\end{tabular}


Table I-1. Maximum Temperature, Highest TC Location - Data. (5 Sheets)

\begin{tabular}{|c|c|c|c|c|c|c|c|c|c|c|}
\hline Tank & 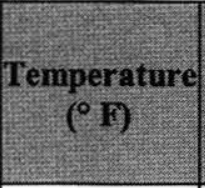 & $\begin{array}{l}\text { Reading } \\
\text { Date }\end{array}$ & Riser \# & TC\# & $\begin{array}{c}\text { Maximum } \\
\text { TC Height In Tank } \\
\text { (inches from tank } \\
\text { bottom) }\end{array}$ & $\begin{array}{c}\text { Maximum Waste } \\
\text { Surface Level } \\
\text { (inches from tank } \\
\text { bottom) }\end{array}$ & $\begin{array}{c}\text { TC Height Above } \\
\text { Waste Surface } \\
\text { (inches) }\end{array}$ & $\begin{array}{c}\text { First } \\
\text { Temperature } \\
\text { Reading Date }\end{array}$ & $\begin{array}{c}\text { Latest } \\
\text { Temperature } \\
\text { Reading Date }\end{array}$ & $\begin{array}{l}\text { Years of } \\
\text { Data }\end{array}$ \\
\hline U-202 & 66.8 & $11 / 13 / 91$ & Historical & 11 & 244 & 27.75 & 216.25 & $7 / 5 / 87$ & $1 / 6 / 94$ & 6.50 \\
\hline U-203 & 57.9 & $02 / 13 / 93$ & Historical & 11 & 244 & 25.7 & 218.3 & $2 / 13 / 93$ & $2 / 13 / 93$ & 0.00 \\
\hline U-204 & 79.9 & $07 / 02 / 93$ & Historical & 16 & 364 & 23.53 & 340.47 & $1 / 1 / 88$ & $7 / 2 / 93$ & 5.50 \\
\hline
\end{tabular}

Notes: $\mathrm{TC}=$ thermocouple 
RPP-11413 Rev. 1

APPENDIX J

DOE CHALLENGE AEROSOL DOCUMENTS SUPPORTING EMORY 3004 FOR THE HANFORD SITE 
RPP-11413 Rev. 1

This page intentionally left blank. 


\section{Department of Energy}

Richland Operations Office

P.O. Box 550

Richland, Washington 99352

SEP $2415 Y 2$

Contractors, Richland, Washington

Mr. T. M. Anderson, President

Westinghouse Hanford Company

Or. W. L Meader, President

Hanford Environmental Health Foundation

Dr. W. R. Hiley, Director

Pacific Northwest Laboratory

Gentlemen:

USE OF EMORY 3004 FOR IN-PLACE HEPA TESTING

In response to inquiries the Headquarters Office of Engineering and Operations Support Defense Programs has agreed Emory 3004 is an acceptable challenge aerosol for in-place high-efficiency particulate air (HEPA) filter penetration testing. Therefore, the Richland Field office (RL) authorizes the use of Emory 3004 for in-place (HEPA) filter testing.

Note: This applies only to the testing of in-place filters and not for the acceptance testing of new filters which is performed by Hanford Environmental Heal th Foundation (HEHF) using a different aerosol.

$\because$ If you need further, information please contact Burt $\mathrm{Hill}$ at 376-6863.

AMO: BEH

Sincerely,

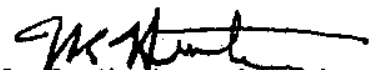

J. R. Hunter, Assistant Manager for Operations

cc:

W. J. Schlauder - WHC

E. R. Hamm - WHC

D. H. Steffen - HAC

c. K. Girres - WHC

J. D. Bright - PNL

J. T. Funk - HEHF 
RPP-11413 Rev. 1

This page intentionally left blank. 
APPROYAL OF EHERY 3004* AS A CHALLENGE AEROSOL

AT WESTINGHOUSE HANFORD CONPANY

\author{
D. A. GILLES
}

\begin{abstract}
Dioctyl phthalate (DOP) has been the standard challenge aerosol material used for HEPA filter testing for the past four decades. In 1980 DOP was determined to be a "Suspect Carcinogen" and later a "Known Carcinogen". As a result the Department of Energy (DOE) issued a recommendation to all contractors to discontinue the use of DOP for aerosol testing. At the Hanford Site in Washington State many materials were tested for use as a replacement. The final product selected was Di-2-ethylhexyl sebacate (DOS). DOS performed satisfactorily producing the required quality of aerosol smoke, but not in the same quantity that DOP produced. It also tended to plug the aerosol generating equipment and creating a great deal of blow by. DOS was eventually. added to the "Suspect Carcinogen" $j$ ist. With the the change of carcinogen status and, consequently the waste handling status of DOS, a search for an alternative material was started.
\end{abstract}

The Search for an alternative to DOS had to deliver a product that would produce the required quality and quantity of aerosol smoke while not being a carcinogen, not producing regulated wastes, not exposing workers to obnoxtous

*Emery 3004 is a trademark of the Henkel Corporation 
fumes and not posing any equipment maintenance problems. Research for the alternate started with the 16th and 21st Nuclear Air Cleaning and Treatment Conference. From there, Emery 3004 was chosen for testing. Emery 3004 proved to meet all of the above criteria. Testing was conducted by Westinghouse Hanford Company (WHC), Hanford Environmental Health Foundation (HEHF) and the United States Army Environmental Hygiene Agency (AEHA). Laboratory testing conducted by HEHF and AEHA determined that emery 3004 met the particle size distribution requirements of American National Standards Institute (ANSI), American Society of Mechanical Engineers (ASME) N510 standard for in place HEPA filter testing. WHC conducted Eight months of field testing which showed that Emery 3004 behaved like traditional aerosols. Based on the results of this testing and with the concurrence AEHA, HEHF, Dames and Moore that Emery 3004 was a suitable replacement for DOS, WHC petitioned the DOE for approval of Emery 3004 as a challenge aerosol for in place HEPA filter testing. On September 24, 1992, the Department of Energy, Richland Operations Office authorized the use of Emery 3004 for in place HEPA filter testing on the Hanford site.

The efforts to find a suitable replacement for DOS have enabled WHC to show a cost savings through reduced maintenance and waste handling costs and has reduced the hazards workers are exposed to. WHC has paved the way for other DOE contractors to receive authorization to use EMERY 3004. Already another DOE contractor Westinghouse Idaho Nuclear Company (WINCO) has visited WHC in order to acquire information to enable them to use Emery 3004. 
RPP-11413 Rev. 1

WHC-SA-1509-A

\section{Emery 3004 As a Challenge Aerosol: Operational Experience at Westinghouse Hanford Company}

C. K. Girres

D. H. Steffen

Date Published

February 1992

To Be Presented at 22nd DOE/NRC Nuclear Air Cleaning Conterence

Denver, Colorado

August 24-27, 1992

Prepared for the U.S. Department of Energy Office of Environmental Restoration and Waste Management

(2) Westingtouss P.O. Box 1970

Hanford Operations and Engineering Contractor for the

U.S. Department of Energy under Contract DE-AC06-87RL10930

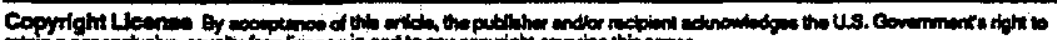

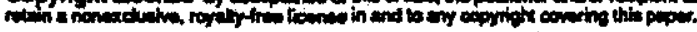

Approved for Public Release 
LEGAL DISCLAIMER

This repon was propared as an account of work sponsored by an agency of the United Stales Government. Noither the United States Government nor any agency thereof, nor any of their employess, nor any of their contractors, subcontractots or their omployees, makes any warranty, express or impliod. or assumes any logal liability or responsibility lor the accuracy, complotoness, or any third party's use or the results of such use of any inlormation, apparalus, product, or process disclosed, or represents that its use would not infringe privately owned rights. Referonce haroin to any specific commercial product, process, of service by trade name, trademark, manufacturer, of othenwise, does not nocessarily constitute or imply its endorsement, recommendation, or lavoring by the United States Government or any agency thereol of its contractors or subeontractors. The views and opinions ol authers expressed hosein do not necessarily state of reflect those of the United States Government of any agancy thereol.

This report has been reproduced from the best available copy.

Prialed in the United Statos of Aneriea

DISCLU-2.CHP (1-3) 
RPP-11413 Rev. 1

WHC-SA-1509-A

EMERY $3004^{7}$ AS A CHALLENGE AEROSOL: OPERATIONAL EXPERIENCE

AT NESTINGHOUSE HANFORD CONPANY

C. K. Girres

D. H. Steffen

\begin{abstract}
High Efficiency Particulate Air (HEPA) filter systems are tested periodically by chemicals such as dioctyl phthalate (DOP) and di-2-ethylhexyl sebacate (DOS) to ensure adequate performance. For eight months, Westinghouse Hanford Company (Westinghouse Hanford) used Emery 3004 as a challenge aerosol for in-place HEPA filter system testing. Although Emery 3004, a noncarctnogenic synthetic oi1, has not been approved officially as a challenge aerosol by the U. S. Department of Energy, Richland Field Office, Westinghouse Hanford gained valuable information from its testing.
\end{abstract}

Operationally, Emery 3004 has several advantages over approved performance testing chemicals, including that it is not considered a carcinogen or suspect carcinogen; therefore, respiratory protection is not required during testing. Additionally, Emery 3004 does not cause buildup on or plugging of the test equipment like DOP or DOS. By reducing the maintenance required on equipment, use of Emery 3004 increases the efficiency of Westinghouse Hanford operations.

The concern with using Emery 3004 for in-place testing of HEPA filter systems has been the lack of definitive data on its particle size distribution when generated with a "cold smoke" generator. Quantitative data was not

'Emery 3004 is a Trademark of the Henkel Corporation. 
RPP-11413 Rev. 1

WHC-SA-1509-A

avallable to show compliance with the particle size distribution requirements of American National Standards Institute, American Society of Mechanical Engineers N510, the standard for in-place testing. To provide comparative data between DOP, DOS, and Emery 3004, Westinghouse Hanford performed a practical field demonstration, and the results indicated that Emery 3004 behaved like the traditional aerosols. Additional preliminary tests were conducted to obtain particle distribution data, and, as a result of this testing, Westinghouse Hanford is taking steps to obtain the approval of Emery 3004 as a challenge aerosol from the U.S. Department of Energy, Richland Field office.

This paper-discusses-the operational-advantages of Emery 3004 and further discusses our test results.

$$
\begin{aligned}
& \text { HEF'A }
\end{aligned}
$$

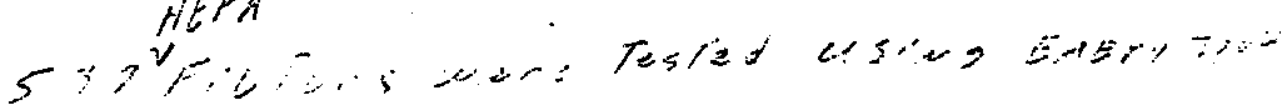

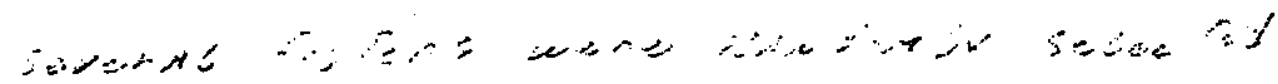

$$
\begin{aligned}
& \therefore \text { 상 }
\end{aligned}
$$

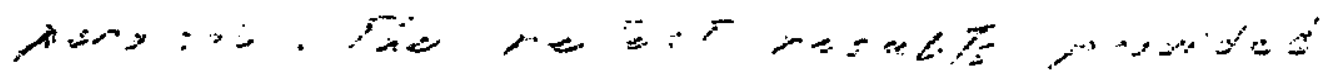

$$
\begin{aligned}
& \text { wext }
\end{aligned}
$$

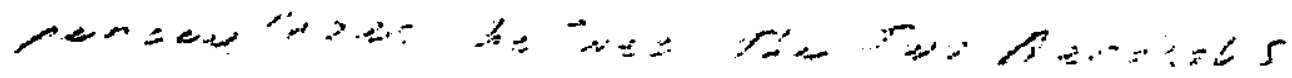

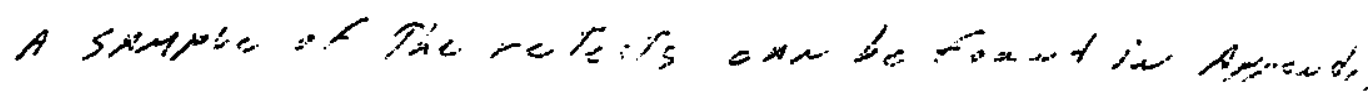

$$
\begin{aligned}
& (?)
\end{aligned}
$$


RPP-11413 Rev. 1

WHC-SA-1509-A

DISTRIBUTION LIST

Number of Copies

OFFSITE

Harvard University Air Cleaning Laboratory

M. W. First, Sc. D, Conference Chairman 665 Huntington Avenue

Boston, Massachusetts 02115-9957

ONSITE

U.S. Department of Energy-Richland Field Office

5

B. E. Hill

A6-53

Hestinghouse Hanford Company

8

C. K. Girres

D. H. Steffen

S4-65

Project Files

Publications Services (3)

Central Fites (2)

S4-65

R1-28

R1-08

L8-04 
RPP-11413 Rev. 1

WHC-SA-1509-A

DISTRIBUTION LIST

Number of Coofes

OEFSITE

Harvard University Air Cleaning Laboratory

M. W. First, Sc. D, Conference Chairman

665 Huntington Avenue

Boston, Massachusetts 02115-9957

ONSITE

U.S. Bepartment of Energy-Richland Field office

5

B. E. Hill

A6-53

Westinghouse Hanford Company

8

C. K. Girres

D. H. Steffen

Project Files

Publications Services (3)

Central Files (2)

S4-65

S4-65

RI-28

RI -08

L8-04 


\section{PRELIMINARY REPORT OF : \\ H.E.P.A. FILTER CHALLENGE AEROSOL CONPARISON TESTS}

Challenge aerosol comparison tests were conducted at Westinghouse Hanford Company to compare the performance of three challenge aerosols; ie., D.O.P., D.O.S., and P.A.O..

The tests were conducted using equipment that is normally used for testing H.E.P.A. filter systems in the field at the Hanford Site. Actual field conditions were simulated in the Vent \& Balance Laboratory in the 2101-M building in the 200 East Area.

The comparison tests were conducted on January 09,1992. Three Air Techniques Incorporated (A.T.I.) Model TDA-5A (hot pot) smoke generators were used, one for each aerosol. Each smoke generator was set to the specifications provided by the test equipment and aerosol manufacturer's recommendations. Three smoke generators were used to facilitate performance of the tests in as short a time span as possible to avoid fluctuations in ambient air pressure and temperature. An A.T.I. Mode1 TDA-2E Penetrometer was used to measure smoke penetration through the test filters.

Two 24 " $\times 24$ " $\times 12 "$ Flanders H.E.P.A. filters were used for the tests. The first test series was conducted using an old filter which had been used several years. The second test series was conducted using a new filter. The third test series was conducted using the OLO filter with an intentional perforation of $1 / 16^{n}$ diameter $\times 2^{n}$ deep located at the filter center. These three tests were performed to generate data that was as similar as possible to actual field conditions and provide a realistic comparison of the aerosols.

All test data, conditions, filters, instrument calibrations and test methods were witnessed and verified by Quality Control and Industrial Safety personne?.

The D.0.P. aerosol was tested at the beginning and conclusion of each series of tests to "bracket" the other two aerosols and assure that the test conditions remained constant.

The data indicates that P.A.O. performs neariy identical to D.O.P. and slightly better than $D .0 . S$. Ali three aerosols performed within $0.15 \%$ of each other. 
The preliminary conclusion based on these tests is:

Page \#2 of 2

$\star$ P.A.O. is a viable candidate for replacing both D.O.P. and D.0.S..

* The test results appear to validate the in place testing of H.E.P.A. filter systems that were tested using P.A.O. as the chalienge aerosol.

A report is being prepaired which will integrate these test results with identified technical information. This report will make recomendations on the disposition of the in place filter tests performed using P.A.O. between $5 / 2 / 91$ \& $1 / 7 / 92$.

Future reports will contain peer reviews of this report, opinions, and data gathered by the aforementioned experts.

CHALLENGE AEROSOL COMPARISON TEST DATA

TEST 1 (USED HEPA FILTER)

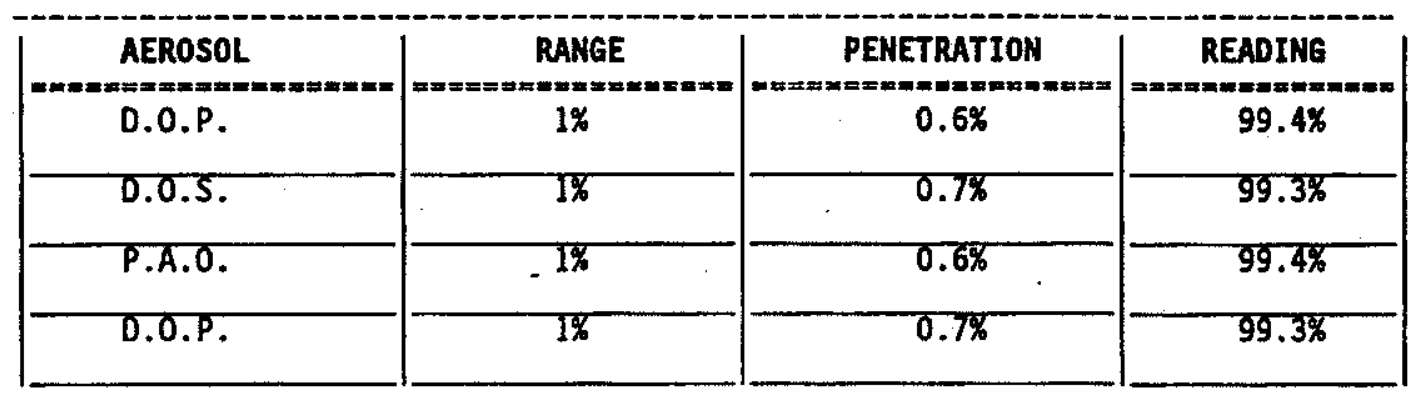

TEST 2 (NEY HEPA FILTER)

\begin{tabular}{|c|c|c|c|}
$\begin{array}{c}\text { AEROSOL } \\
\text { D.0.P. }\end{array}$ & $\begin{array}{c}\text { RANGE } \\
\text { PENETRATION }\end{array}$ & $\begin{array}{c}\text { READING } \\
1 \%\end{array}$ \\
\hline D.0.S. & $1 \%$ & $0.002 \%$ & $99.998 \%$ \\
\hline P.A.0. & $1 \%$ & $0.002 \%$ & $99.998 \%$ \\
\hline D.O.P. & $1 \%$ & $0.003 \%$ \\
\hline
\end{tabular}

TEST \$3 (USED HEPA FILTER. PERFORATED)

\begin{tabular}{|c|c|c|c|}
\hline 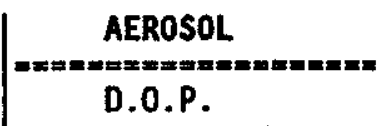 & $\begin{array}{c}\text { RANGE } \\
1 \%\end{array}$ & $\begin{array}{c}\text { PENETRATIOK } \\
0.3 \%\end{array}$ & $\begin{array}{c}\text { READING } \\
=0=x .7 \% \\
99.7 \%=m\end{array}$ \\
\hline D.0.5. & $1 \%$ & $0.2 \%$ & $99.8 \%$ \\
\hline P.A.O. & $1 \%$ & $0.35 \%$ & $99.65 \%$ \\
\hline 0.0 .9 . & $1 \%$ & 0.38 & $99.7 \%$ \\
\hline
\end{tabular}


[1] From: Byron $H$ Ruelas II at WHC167 1/15/92 12:21PM (2703 bytes: 58 In)

To: David H Steffen at $\sim$ WHC26

cc: Stephen L Brey, Danje1 A Conners at WHC110, Cynthia K Girres at $\sim W H C 26$

Subject: RETEST OF HEPA FILTERS

A RETEST WAS PERFORMED ON ALL HEPA FILTERS WHICH WERE

PREVIOUSLY TESTED USING THE UNAPPROVED CHALLENGE AEROSOL

EMERY 3004 AT THE 222-S LABORATORY. A COMPARISON THE TEST

RESULTS ARE AS FOLLOWS:

THE HEPA FILTER ON HOOD NO. 6 IN ROOM IGB WAS TESTED ON

5/20/91 USING EMERY 3004 WITH THE FOLLOWING RESULT: .002\% PENETRATION.

THIS SAME HEPA FILTER WAS AGAIN TESTED ON 1/13/92 USING DOS

WITH THE FOLLOWING RESULT: .002\% PENETRATION.

THE HEPA FILTER ON HOOO NO. T IN ROOM IL WAS TESTED ON

10/25/91 USING EMERY 3004 WITH THE FOLLOWING RESULT: .002\% PENETRATION.

THIS SAME HEPA FILTER WAS AGAIN TESTED ON $1 / 13 / 92$ USING DOS

WITH THE FOLLOWING RESULT: .002\% PENETRATION.

HEPA FITTER TESTING FOR THE 222-SC FILTER BUILOING USING

EMERY 3004 WAS CONDUCTED ON $8 / 29 / 91$. THE FILTERS WERE

AGAIN TESTED ON 1/14/92 USING DOS, WITH RESULTS AS FOLLOWS:

$\begin{array}{ccc}\text { WEATHER CONDITIONS: } & 8-29-91 & 1-14-92 \\ \text { AIR TEMP. } & 93^{\circ} \mathrm{F} & 36^{\circ} \mathrm{F} \\ \text { HUMIDITY } & 43 \% & 88 \% \\ \text { AIR PRESS. } & 29.17 & 29.58\end{array}$

THE 8-29-91 TESTS WERE PERFORMED BY A PERSON WITH MANY YEARS OF EXPERIENCE, USING A STANDARD WORK PROCEDURE.

THE 1-14-92 TESTS WERE PERFORMED BY A PERSON RELITIVLY NEW TO THE JOB, USING THE SAME STANDARD WORK PROCEDURE, BUT WITH A SKECH ATTACHED, DEFINING PERTENANT TEST POINTS. 
RPP-11413 Rev. 1

NOTE: THE FOLLOWING FILTERS ARE "PAIRED" WITH THE OOD NUMBERED FILTER IMEDIATLY UP-STREAM OF THE EVEN NUMBERED FILTER. THE \#9 FILTER IS A SINGLE EXHAUST FILTER.

\begin{tabular}{|c|c|c|}
\hline FILTER NO. & $\begin{array}{c}\text { * PENETRATION } \\
\text { Emery } 3004 \\
8-29-91\end{array}$ & $\begin{array}{c}\text { * PENETRATION } \\
\text { D.0.S. } \\
1-14-92\end{array}$ \\
\hline $\begin{array}{l}1 \\
2\end{array}$ & $\begin{array}{l}.002 \\
.003\end{array}$ & $\begin{array}{l}.004 \\
.005\end{array}$ \\
\hline $\begin{array}{l}3 \\
4\end{array}$ & $\begin{array}{ll}. & .012 \\
& .028\end{array}$ & $\begin{array}{l}.020 \\
.020\end{array}$ \\
\hline $\begin{array}{l}5 \\
6\end{array}$ & $\begin{array}{l}.010 \\
.024\end{array}$ & $\begin{array}{l}.015 \\
.015\end{array}$ \\
\hline $\begin{array}{l}7 \\
8\end{array}$ & $\begin{array}{l}.005 \\
.003\end{array}$ & $\begin{array}{l}.002 \\
.002\end{array}$ \\
\hline 9 & .002 & .004 \\
\hline $\begin{array}{l}10 \\
11\end{array}$ & $\begin{array}{l}.036 \\
.046\end{array}$ & $\begin{array}{l}.030 \\
.030\end{array}$ \\
\hline
\end{tabular}


RPP-11413 Rev. 1

APPENDIX K

VENTILATION DISCUSSION WITH HANFORD SITE ENGINEERING STAFF 
RPP-11413 Rev. 1

This page intentionally left blank. 
RPP-11413 Rev. 1

\section{VENTILATION - ERIC BERGLIN DISCUSSIONS WITH TERRY KAISER,}

JUNE 13, 2002, 2:00 PM

\section{Following are applicable excerpts from Mr. Eric Berglin's discussions with Terry Kaiser on June 13, 2002 at 2:00 pm. Items that have been added for clarification to the reader but are not part of the exact original message are shown in italics.}

\section{Terry Kaiser is a System Engineer in Hanford West Tank Farms.}

1. Inlet Filter $\mathrm{dP}$ (Active System) - The inlet filter $\mathrm{dP}$ is generally not a problem as in many systems, even if the filter is plugged, there is often enough in-leakage that system remain operable. For these filters, the in-place leakage test is where the filter conditions are noted. Action: May be able to eliminate $\mathrm{dP}$ requirements for some or all of the inlet HEPA filters on active systems.

2. Inlet Filter Configuration - On active ventilation systems, some systems have up to two HEPA filters in series. Action: None, this is already covered in OSD.

3. In-place Leak Test For Systems Not Conforming to N510 - Per TFC-ENG-STD-C-07. 2.9 Testing and Maintenance, it states, "ASME N510 shall be used as testing guidance for those systems that were not designed to the ASME N509 requirements." Per Terry, this requirement has changed and currently no technical basis has been documented for these systems. Some systems have AG-1 compliance matrixes but these are general held by individual and not readily available. Action: Since the majority of HEPA filter systems at Hanford Site tank farms fall into this category, this should be reviewed by the Design Authority (DA) Ed Dalpiaz. Per Terry, these requirements come from the DAs.

4. In-place Leak Test Flow Rate and Frequency - Terry says that these test are done at the design flow of the "system" and not at the "maximum rated flow of the manufacturer." In addition, this test is performed whenever the "design flow rate of the system" is changed. This requirement especially applies to the portable exhausters that are moved around. In general, the Tank Farm systems have a set flow rate, but sometimes they are changed. Terry said there is some tolerance in the system as they vary slightly. When asked if this were put in as an OSD requirement, what would Terry consider a significant change, ranges like $10 \%, 15 \%, 20 \%$, and over $100 \mathrm{cfm}$ were discussed. Action: Consider adding requirement to do In-place Leak Test whenever system design flow rate is changed by $15 \%$ or $200 \mathrm{cfm}$ (whichever is greater).

5. Name Changes From "Filter Efficiency" to "In-Place Leak Test" - Terry was concerned that new wording did not match the FSAR/TSR but did verify that this changed name is that used in the ventilation standards and guidance documents. Action: Consider providing more cross-references to the FSAR/TSR by changing name to "In-Place Leak Test (formerly call Filter Efficiency) to avoid confusion. Consider submitting change to FSAR/TSR to correctly state requirement. 
6. In-Place Leak Test particle size removed - Terry was concerned that this change did not match the FSAR/TSR but did verify that the "0.3-micrometer" is not called out in ventilation standards and guidance documents for this test. Action: Consider submitting change to FSAR/TSR to correctly state requirement. 
RPP-11413 Rev. 1

APPENDIX L

HANFORD SITE TANK FARM VENTILATION DISCUSSION WITH HANFORD SITE TANK FARM ENGINEERING STAFF 


\section{RPP-11413 Rev. 1}

This page intentionally left blank. 


\title{
HANFORD SITE TANK FARM VENTILATION DISCUSSIONS WITH HANFORD SITE TANK FARM ENGINEERING
}

\begin{abstract}
Following are applicable excerpts from Mr. Eric Berglin's discussions with Ed Dalpiaz on June 11, 2002 at 11:00 am. Items that have been added for clarification to the reader but are not part of the exact original message are shown in italics.
\end{abstract}

Ed Dalpiaz is a Design Authority for ventilation system in Hanford Tank Farms.

$\mathrm{Ed}$,

Notes, issues, and actions from our discussions yesterday.

Meeting with Ed Dalpiaz / Eric Berglin June 11, 2002 at 11:00 am

1. HEPA Configuration

a. Double-Shell Tanks (DSTs):

1. On Primary Inlet-HEPAs on AN, AW, AY, AZ, and SY. There is no HEPA filter, or any filter on the inlets of AP tanks. AP is an anomaly, per Ed Dalpiaz and he was not familiar with the background on why the tanks did not have inlet filters. In flow is through various air infiltration pathways. The tanks are not sealed pressure vessels.

2. On Primary Outlet - HEPAs on all tanks

3. On Annulus Inlet - HEPAs on AN, AP, AW, SY tanks. AY and AZ tank ventilation inlets do not have HEPA filters but filters slightly less than the efficiency of a HEPA.

4. On Annulus Outlet - HEPAs on all tank farms.

b. Single-Shell Tanks (SSTs):

1. Passive Ventilation - HEPAs on all tanks

c. Ed has not been able to find the technical design basis for the DST AP lack of inlet filter anomaly.

2. HEPA Temperature Limit

a. A temperature limit of 200 degrees F is stated in ASME N509 above which the HEPA filter shall have steel cases.

3. HEPA Differential Pressure

a. Split up systems into Passive, Active, Inlet, Outlet, First Filter, Filter Series, Pre Filter, Post Filter, Filter groups in series, as appropriate. This will probably be done as a table in each OSD. The system design as related to differential pressure measurements may need to be done to assure all configurations are covered. 
b. Add the Gustavson set point document as basis document RPP-5594. Note: RPP-5594 appears to suggest a minimum 0.2 inches water gauge set point instead of the 0.1 listed in the TSR. The reason for this inconsistency is not known at this time.

c. Use the maximum values of 4.0 (inlet and exhaust filters after the first) and 5.9 (first exhaust) inches water gauge.

d. Through discussions with the Nuclear Safety personnel, the requirements in the FSAR/TSR of 5.9 and 0.1 came directly from the OSDs with no other basis than that. Eric suggested to Ed that the FSAR/TSR limits possibly have greater range limits (10.0 maximum) and (greater than 0 minimum). With this change, Eric's suggested maximum limit of 6.0 verses the current 5.9 could be used. As the FSAR/TSR will not be changed anytime soon, the 5.9 and 0.1 limits as currently stated in these documents will be matched by the OSD.

Note: Per Bob Gustavson, a Hanford tank farm Design Authority (DA), the 0.1 in. w.g. differential pressure limit discussed above came from an evaluation of flow verses differential pressure charts from Flanders Filters, Inc. This evaluation was based upon some exhausters in the FSAR differential pressure interlock scope that were operating well below the design flow rate. The $0.1 \mathrm{in}$. w.g. differential pressure limit was chosen as the highest possible lower limit without risking spurious low differential pressure alarms from low flow conditions in these few exhausters.

e. Ed suggested that if the OSD would use a new value and more conservative below the 5.9, such as 5.0, it would not be as much as a problem to change but something greater than 5.9, exceeding the FSAR/TSR requirements should not be done.

4. HEPA Efficiency

a. Change this title "HEPA Efficiency" to correctly state the actual function "HEPA In-Place Leak Test"

b. Change "efficiency" to "\% penetration" to match standards wording. The word "efficiency" for in-place HEPA testing is not correct terminology. Instead, "efficiency" is the proper terminology for manufacturer qualification and production testing.

c. Remove the 0.3-micrometer diameter reference at this is incorrect. Instead, use "DOE approved aerosol" that will include polydisperse liquid DOP or the DOE-RL approved substitute Emery 3004.

5. Filters covered in OSDs

a. For this OSD update, only HEPA filters, to include there associated prefilters and postfilters if required, will be addressed. Other filters, such as those on the DST Annulus Inlet of AY and AZ that are not HEPAs, will not be addressed at this time but will need to be addressed eventually.

6. Ventilation Configuration 


\section{RPP-11413 Rev. 1}

a. There is no document that currently describes all the various ventilation system components and configurations for systems covered in the OSDs. 
RPP-11413 Rev. 1

APPENDIX M

OLDER TECHNICAL BASIS LETTERS FROM WHC-SD-TI-008 
RPP-11413 Rev. 1

This page intentionally left blank. 


\section{Internal Lette:}

Dav Warch 27, 1980

TO.

- TFPC FIle
5.) Rockwell Internationa! 44 $A=.65260-80-0905$ SO-RE-TI-OC.

- T. J. Entt

- Tank Farm Process Control

- 2750-E/200-East

. 942-1149

subuet. . AN Tank Farm Process Specfficatlons - HEPA FIlters

References: 1) Bulletin Mo. 1508-B, Hine Safety Appliances Co. "ySA Ulera Atre Filters"

2) C. A. Gunn and D. H. Exton, "HEPA Filter Performance Comparative Study". Ftltor Appl jeations Enginaering. Mipe Safoty Appliances Company. Presented at 14th Eath Air Cleaning Conference.

3) HPS-151-H, Rov 2, Hay 27, 1976, "Standard Spectfleation For High Efffeteney Partieulate Air Filters"

4) Gask-0-Seal Handbook, Issue 65411. Parker Seal Co. (1974)

5) Bullentin No. 1500-13, Mine Safaty Appliances Co. "MSA. Filter Systems Guide"

This letter is being issued as a reviston to 11 65260-80-0880 and supports the following limtts in RHO-iHA-15i. Section 6 .

Vartable Spectification Limit

HEPA Filters :

Pressure drop across filters

a) Pressure drop across first filter $\leq 5.9$ inches water gauge ( $\hat{W}^{\mathrm{w} . \mathrm{g}}$ ) In a sertes.

b) Pressure diop across any other filter.

$\leq 4.0 \mathrm{m.g}$.

c) Total pressure drop across fitters in a series.

$\leq 5.9 \mathrm{~m}_{\mathrm{w} . \mathrm{g}}$.

Air Iniet Temp, To HEPA Ffiter

$\leq 230^{\circ} \mathrm{F}$

The variables and limits apply to the priany and annulus ventflation system. The HEPA filters are dastgned to operate continuously at a pressure drop of $10 \mathrm{W.g}$. (Reference 5) and withstand pressure surges of $28 \mathrm{W.g}$. (Reference 2) while mantaining the specifled efficfency (99.975). Reforence 3 states requirements for HEPA fliters and retaining systems used at Hanford. 
TFPC Ftle

Page 2

March 27, 1980

The 1 fmit of 5.9 W.g. pressure drop across the first filter in a series provides a safety factor to allow for decreased filter strength due to aging and detarioration. This pressure drop $(5.9 \mathrm{w.g.})$ is higher than the rest of the fliters because the first flitar willi trap most of the material in the afrstrein, thus loading up much faster than the "downstrean" fliters. The 4 W.g. Ifatt is sot for the downstrean HEPA fllters to raduce the posstbility of filter fallure. Thts added safety factor is used since the downstrean filtars are. the only renainting barrior to the atmosphere. The totel pressure drop across the fllters in a sertes is ilarited to 5.9 W.g. so that a vacur is maintained on the tank. The primary tank exhaust fan (K-1) is Incapable of pulling a vacusin greater than 5.9 W.9. (see drawing H-2-70340). Therefore, a total pressurs drop grater than 5.9 W.g. Will mean that the tank is not under vacuin. A vacuum is needed to mintalze the release of radionucildes from the tank vapor space to the attrosphere.

The two annulus exhaust fans $(K-2)$ are capable of pulling a vacuum of 14.2 w.g. Although the possiblifty exists for subjecting the HEPA fiters to this vacuun, the ffiter would have to load up from a 2 to 3 "w.g. d.p. to 14 w.g. dp in less than 8 hours. The tank pressure monftors wili alarm when the tank vacuum is -.25 w.g. , therefore the alarm will Indirectly indicate that the filter may be loading up. This alarm will minimize the time that the filter will be subjected to high d.p.'s. As noted earifer. the fflter is designed to withstand pressure surges of up to $28 \mathrm{m.g}$.

The pressure drop 11 int of 5.9 "w.g. for the rirst HEPA fllter in a sartes has proved satisfactory from operattonal experience while providing an acceptabie safety margin. Material bufldup on a HEPA fflter causes an increased pressure drop. HEPA filters used on the tank farms tend to "load up" slowiy until a pressure drop of 2 to 3 inches water gauge is reached. Further pressure drop increases take place much faster. The 5.9 w.g. Ifmt on the first filter is high enough so that an ample amount of time is avallable for fllter changeout, which is normally done for all HEPA fllters when the pressure drop approaches 3 W.g. Since the downstream filters load up slowly, a 4 "w.g. Iftrit allows adequate time for fllter changeout. 
TFPC File

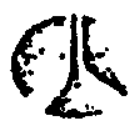

Page 3

March 27. 1980

The maximum air inlet tenperature to the HEPA filtars is $230^{\circ} \mathrm{F}$. This i iuft is set to serve as en indirect control of the tank concrete temperature and to prolong the life of the HEPA filter gasket marial.

The process specification 1 imit for the conerete touperature allows a maxtmen of 236 F. To privent this temperature from befing exceeded. the 230'F HEPA fllter liuft (225\%F before the alr haster) bas been set.

The neoprene gasket wateriai is the teaparature ifutiting factor for the HEPA filter systein and has a aximan rating of $300^{\circ} \mathrm{F}$ (Raference 4). However, the vendor recoumends the filter be subjected to temperatures of $250 \%$ or less (Roference 1 ).

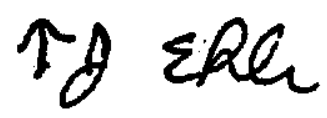

T. J. Ehi1

Tank Farm Process Control

TJE!lı 1 JO

Approved 8y: it in 8 iw betar

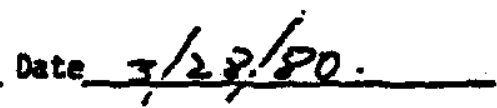

ce: T. J. EhIt

.28 
Internal Letter

ben. Wareh 12, 1981

TO:

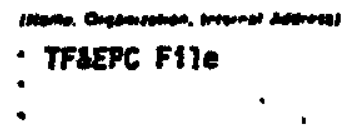

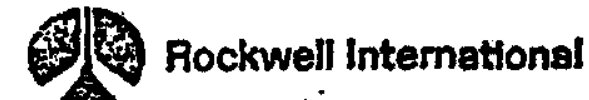
No. 55260-81-102

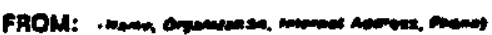

- W. K. Mare

$3-3514$

Subper: SUPPORTING DOCHMJTATIOA FOR PROJECT B-180/B-135 PROCESS SPECIFICATIOHS: HIPA FILTER AIR TEMPSRATURES

References: a) hPs-151-H, Raviston 2, Hay $27,1976$. Standard spectification for High Efflefency Particulate Air Ftters"

b) Anertean Afr Ftlear catalog

c) Fianders Filter Catalog

d) Camiridge Fifter Catalog

This letter supports the $250^{\circ}$ maxtmm air tenperature linit set on the HEPA filtars used for the salt will rocelver vessals ventilation systeas. Reference (a) above states the winimin requirewents for hEPA filters used at hanford. Reference (a) is currently befing revised and will spectify type "C" hisA fliters must be able to withstand a maxtimin air temperature of $250^{\circ} \mathrm{F}$. The uanufacturers. specifications for HIEPA ffiters are found in the above References (b), (c), and (d). Their low teuperature Heph fliters are all capable of wthstanding continuous temperature of $200^{\circ} \mathrm{F}$ to $250^{\circ} \mathrm{F}$.

A 250" $\mathrm{F}$ air temperature Ifort on the UEPA filters wll be suffletent if the tank liquid and solids resch thair maximum tenperature specification limit of $200^{\circ} F$ due to the heat loss frow the pipes between the tank and the HEPA filter bank.

The attachuent provides the heat transfer analysis to dotenine the maximin temperature to be experienced by the UEPA fifters when the electric heater is energized. The calculations determined the HEPA filters will see a worst case maximun temperature of $140^{\circ} \mathrm{F}$.

\section{Wh hoore 3-10-81}

H. X. Moore

Tank Farm \& Evaporator

Process Contro]

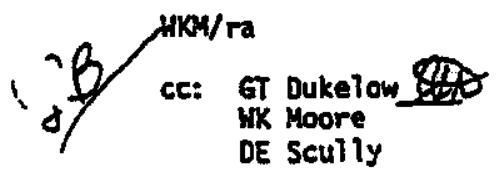


RPP-11413 Rev. 1

APPENDIX N

BREATHER FILTER BASIS FROM WHC-SD-WM-TI-352

N-1 


\section{RPP-11413 Rev. 1}

This page intentionally left blank. 


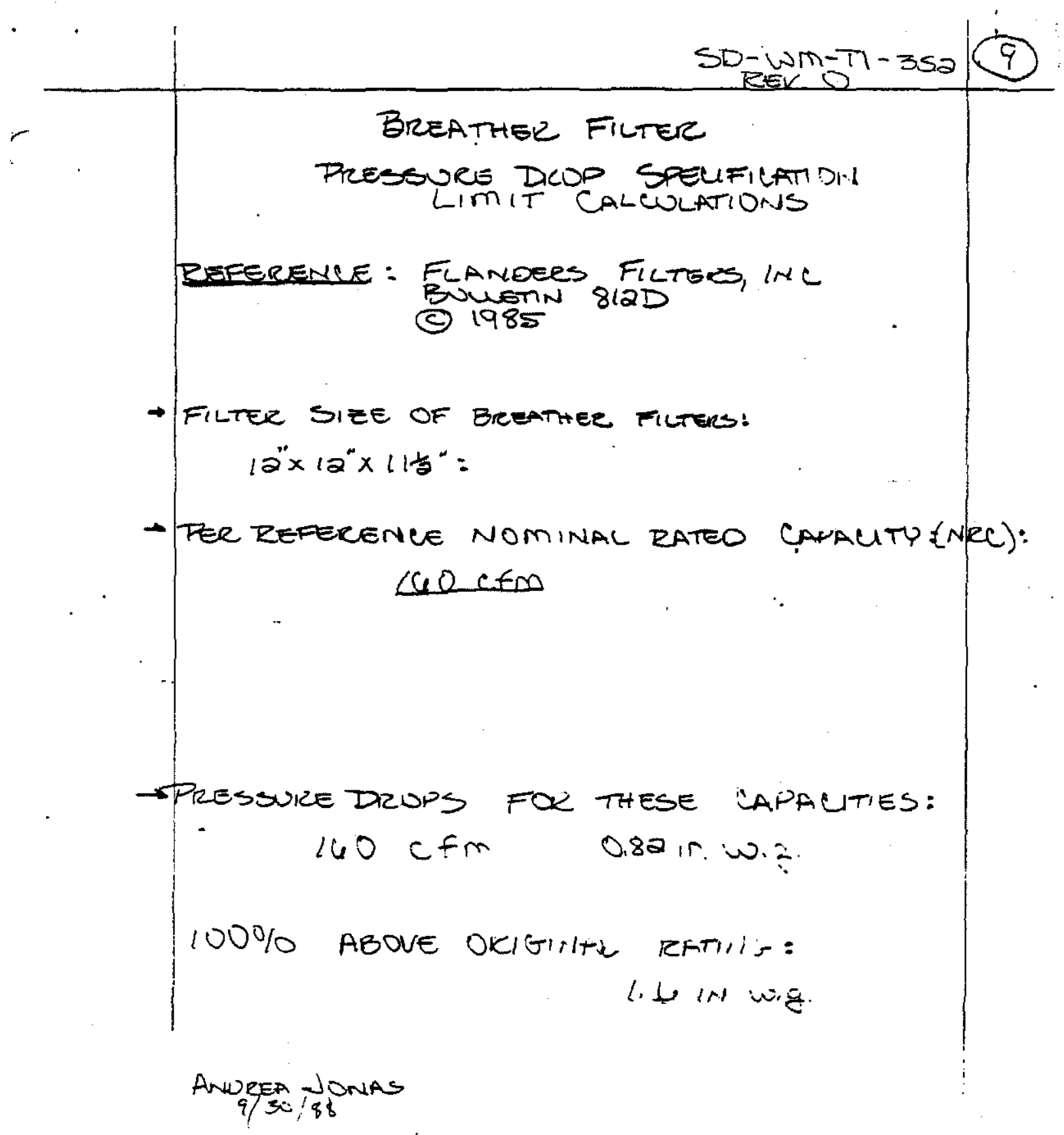


RPP-11413 Rev. 1

This page intentionally left blank. 
RPP-11413 Rev. 1

\section{APPENDIX O}

TEMPERATURE DATA FOR NEOPRENE - DUPONT/DOW 
RPP-11413 Rev. 1

This page intentionally left blank. 
August 2, 2002

Mr. Eric Berglin

Mechanical Engineer

COGEMA Engineering Corporation

2425 Stevens, Second Floor

Richland, WA 99352

RE: Use of Technical Information on Neoprene

Dear Mr. Berglin:

This will confirm that you have approval to use information about Neoprene from our published technical literature in the report you are writing about seals for your HEPA filters.

Please note that although DuPont invented Neoprene, it is now a product of DuPont Dow Elastomers, a joint venture formed in April 1996 by the DuPont Company and The Dow Chemical Company.

Sincerely,

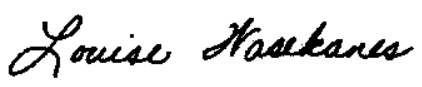

Louise Wasekanes

Communications Coordinator 


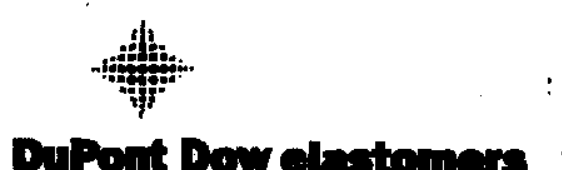

Wimington, DE

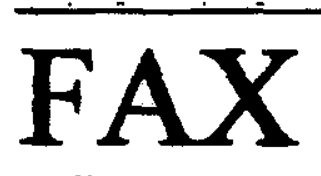

\section{DATE $7-2 G-02$ \\ NUMAER OF PAGiss (nebuting Cove Page) 3}

To:

\section{LOCATION:}

FAX NUMAR: $509-373-4641$

PHONE NUMBER:

Frov:

LOCATION:

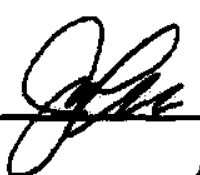

PFONT NURABR:

FAX NUMAER: (302) $892-7390$

RROJECT NAME/*

Non-Buible [ ]

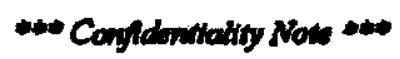

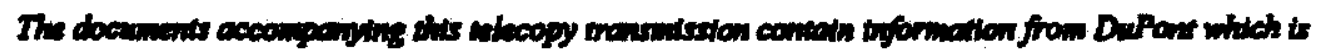

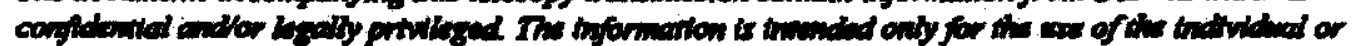

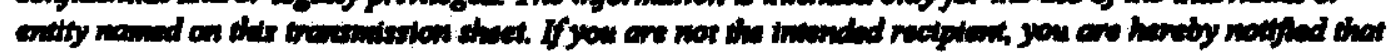

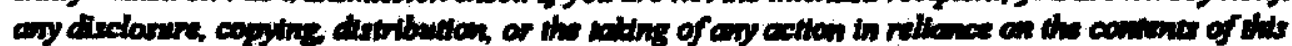

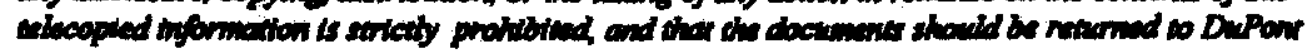

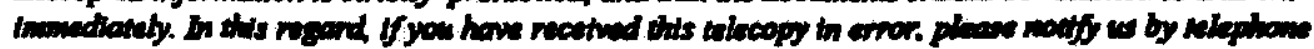

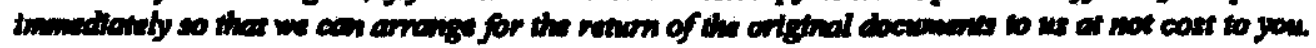




\section{reoprene DAM Shitrl}

Truds Name:

Cosumen Nanses

ASTM Daco Chatillention:

ASTM D1419 Destorition:

POLYUEA PROPEATIES

Speelilie Eravty:

Specitio Hact Capactly:

MECHANRCAL PROPERTES

Hurdinee, Shore A:

Tenelle Sturesth (x10 pel):

Elongation, \%:

Tenalle Modutus at 100\% Elongetion (x10 peli):

Tear Findutanes:

Abration realutanco:

Robound Feolilenee, \% (Beyshoro):

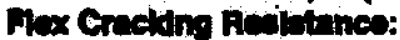

Hystereets Pacletanoe:

Compreaton Set Rating:

Astin Boses, Nothod B:

Cosfleivint of Frietion

Statio (ve Stodid):

Dynomic (v Steel):

\section{ELECTRICAL PFOPERTES}

Voleme Resletwity (ohmem):

Dielsetire Strength (volta/milf):

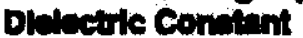

$6 \mathrm{Ht}$

Itrik:
Neoprene Synthotic Rubber

Polychloroprene

BC \& BE

CR

1.23

15 to 95

to 4.0 (1027.6 Mpa)

to 800

to 3.0 (to $20.7 \mathrm{Mpa}$ )

Excollent

$110 \mathrm{pli}$ at $77^{\circ} \mathrm{F}\left(19.9 \mathrm{kNm}\right.$ at $\left.25^{\circ} \mathrm{C}\right)$

Goodrexcillent

$50-80$

Good

Fair/Good $20-60,70 \mathrm{hr} / 212^{\circ} \mathrm{F}\left(100^{\circ} \mathrm{C}\right)$

0.89 to 0.85

$-$

$1.0 \times 10^{11}$ to $2.0 \times 10^{13}$

Good/Excellent (400-700)

8.0

6.7

\section{THERULL PROPERTES}

Min. Continuous Sarviee Temp. ("F): $80^{\circ} \mathrm{F}\left(-622^{\circ} \mathrm{C}\right)$

Mx. Continuous Service Temp. ("F); 180 to $200^{\circ} \mathrm{F}$ (82 to $93^{\circ} \mathrm{C}$ )

Thermal conducthity:

0.11

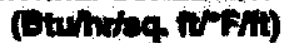

Linar Cochlieient of Thomed Expanalon (intings $\left.\times 10^{\circ}\right)$ :

Cices Tranaltion Temp. ("P): (trom DSC)

\subsubsection{0}

40 to $-45^{\circ} \mathrm{F}\left(40\right.$ to $\left.-49^{\circ} \mathrm{C}\right)$

COMPATILALITY

Weither Realetances:

Ooono Rualedince:

Oxtdation Realutonow

Radlation Roolutance:

Steam flealotince:

Water Reedotwnea:

Fiuldo Reolutance

Not Recommended/Good

Good/Excellent (Rwke/150 ppm)

Excollent

Good, $1 \times 10^{6} \mathrm{Ga} \mathrm{Gy}$

Fair, $8 \times 10^{6} \mathrm{Ga} \mathrm{GY}$

Cood

Fair/Good 
RPP-11413 Rev. 1

Chlorinniad Eotwenta:

Not Recommended

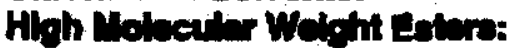

Low Moloouler Woloht Letera:

Hydrocutoon Funlasolvitis:

Hydrocenten Oth/orenen:

Not Recommended

Not Recommendad

Not Recommended

Low Iloberler Weloht Aleohole:

Mineral Aclidas

Fair

Streng Bawe:

Streng Organle Aoldes

Excellont

Cood

Excellent

Good/Excaltent

\section{COMMENTS}

O-6 